\title{
SOME EFFECTS OF IDENTITY-BASED SOCIAL MOVEMENTS ON CONSTITUTIONAL LAW IN THE TWENTIETH CENTURY
}

\author{
William N. Eskridge, Jr*
}

\section{TABLE OF CONTENTS}

I. CONSTitutional ARguments and StRategies

DEPLOYED BY THREE TWENTIETH CENTURY IDENTITY-

BASED SOCIAL MOVEMENTS...................................................2069

A. The Civil Rights Movement ................................................2072

1. The Politics of Protection, 1913-40 ................................ 2073

2. The Politics of Recognition and Some Remediation, 1940-72

3. The Politics of Remediation and the New Politics of

Preservation, 1972-Present ........................................... 2096

B. Women's Rights Movements ................................................. 2113

1. The Politics of Protection: Women's Control of

Their Own Bodies, 1916-72

2. Feminists' Politics of Recognition, 1961-76

3. The Politics of Remediation and the New Politics of Preservation, 1976-Present

C. Gay Rights Movement

* John A. Garver Professor of Jurisprudence, Yale Law School. B.A. Davidson; M.A. Harvard; J.D. Yale. - Ed. I am very grateful to Liora Brener, Jillian Cutler, Jason Cyrulnik, Lisa Mahle, and David Sweet (all Yale Law School class of 2004 and wonderful students in my fall term 2001 procedure class) for excellent research assistance. Gene Coakley and Kris Kavanaugh, both of the Yale Law School, provided invaluable assistance in gathering needed primary and secondary sources. This Article benefited from questions and comments I received when presenting drafts of it at the law schools of McGill University, the University of Michigan, Northwestern University, the University of Minnesota, and Ohio State University, and at a luncheon of Yale Law School graduates. In addition, I benefited from conversations with or written comments from Jeffrey Berger, Jim Brudney, Steven Calabresi, Jim Chen, Ruth Colker, Jack Cound, Dan Farber, Andrew Koppelman, Brett McDonnell, David McGowan, Miranda Oshige McGowan, Stephen Smith, and William Tetley.

I appreciate the great cooperation of the staff of the Supreme Court Library and of the Manuscripts Division of the Library of Congress. The former made available to me thousands of Supreme Court briefs and dozens of oral arguments. The latter facilitated my use of the Papers of the following Justices: William J. Brennan, Harold Burton, William $O$. Douglas, and Robert Jackson. I also thank Mrs. William J. Brennan for granting me permission to use and refer to the Brennan Papers. 
1. The Politics of Protection, 1946-69

2. The Birth of a Politics of Recognition, 1961-81 ..........2169

3. The Ongoing Politics of Recognition and Remediation and the Politics of Preservation, 1981-Present.

II. IDENTITY-BASED SOCIAL MOVEMENTS AND THE EVOLUTION OF CONSTITUTIONAL DOCTRINE

A. Procedural Due Process: National Rules of Criminal Procedure, Dialectical Federalism, and Vagueness as an Anti-Discretion Doctrine 2202

1. Selective Incorporation of Procedural Protections in Criminal Cases. 2204

2. Habeas Corpus and Dialectical Federalism: Federal Courts as Monitors of State Criminal Proceedings .... 2219

3. The Vagueness Doctrine as a Mechanism for Restricting Law Enforcement Discretion...

B. Substantive Due Process: The Right to Sexual Privacy ..2236

C. Equal Protection's Sliding Scale: Suspect Classifications, Invidious Motives, and Fundamental

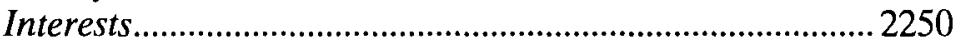

1. Tiers: The Story of Suspect and Other Classifications 2251

2. Legislative Motivation and Fundamental Interests: The Equal Protection Sliding Scale 2269

3. The Disaggregation of Suspect Classifications and Subordinated Classes

D. The Death Penalty Cases: Equal Protection and the Eighth Amendment

E. Equal Protection and the Shifting Fortunes of the Political Question, Federalism, and State Action Doctrines 2299

1. Voting Cases and the Displacement of the Political Question Doctrine 2300

2. Federalism and Expanded National Authority to Protect Civil Rights

3. State Responsibility for Discrimination ........................22324

F. The Imperial First Amendment ........................................... 2332

1. Beyond Speech and Assembly: Expressive Conduct and Association

2. The Sexualized First Amendment .................................... 2340

3. First Amendment-Equal Protection Clashes: Defining Who We Are by Whom We Exclude 2349

III. IDENTITY-BASED SOCIAL MOVEMENTS AND METACHANGES IN CONSTITUTIONAL DisCOURSE AND JURISPRUDENCE 
A. Legal Realism, Social Movements, and the Living

Constitution.

B. Legal Process and Pluralist Theories of Judicial Review 2375

C. Constitutional Skepticism and Popular

Constitutionalism

1. Inefficacy: Disappointment with the Court's

Pragmatic and Institutionalist Responses to the

Politics of Recognition and Remediation

2. A More Aggressive Politics of Remediation: Missed Opportunities for a Politics of Transformation ........... 2394

3. A Deeper Politics of Protection: Court-Based Constitutionalism as an Impediment to Combating Private Violence Against Minorities

What motivated big changes in constitutional law doctrine during the twentieth century? Rarely did important constitutional doctrine or theory change because of formal amendments to the document's text, ${ }^{1}$ and rarer still because scholars or judges "discovered" new information about the Constitution's original meaning. ${ }^{2}$ Precedent and common law reasoning were the mechanisms by which changes occurred rather than their driving force. My thesis is that most twentieth century changes in the constitutional protection of individual rights were driven by or in response to the great identity-based social movements ("IBSMs") of the twentieth century. ${ }^{3}$

Race, sex, and sexual orientation were markers of social inferiority and legal exclusion throughout the twentieth century. People of color, women, and gay ${ }^{4}$ people all came to resist their social and legal disabilities in the civil rights movement seeking to end apartheid; various feminist movements seeking women's control over their own bodies and equal rights with men; and the gay rights movement, seeking equal rights for lesbigay and transgendered people. All these social

1. See David A. Strauss, The Irrelevance of Constitutional Amendments, 114 HARV. L. REV. 1457 (2001).

2. Although scholars and judges are "discovering" new constitutional meanings all the time, most (maybe almost all) of the "discoveries" rest upon thin historiography. See generally Martin Flaherty, History "Lite" in Modern American Constitutionalism, 95 COLUM. L. REV. 523 (1995); Mark Tushnet, Interdisciplinary Legal Scholarship: The Case of History-inLaw, 71 CHI.-KENT L. REV. 909 (1996).

3. Social movements have driven most of the big changes in American constitutional law. The American Revolution and the founding period were the products of a generationbased social movement. The Reconstruction amendments were the ultimate fruition of the abolitionist movement. The union movement and reactions against it drove much of constitutional law during the Lochner era and overlapped with the civil rights movement that commences the story I am telling in this Article.

4. I use the term "gay people" to refer to lesbians, bisexuals, and gay men. Sometimes, I shall use the term "lesbigay." 
movements sought to change positive law and social norms. In both endeavors, constitutional litigation was critically important. Specifically, these IBSMs became involved in constitutional litigation as part of three different kinds of politics in which they were engaged: their own politics of protection against state-sponsored threats to the life, liberty, and property of its members; their politics of recognition, seeking to end legal discriminations and exclusions of group members and to establish legal protections against private discrimination; and a politics of remediation, to rectify material as well as stigmatic legacies of previous state discrimination. At every stage, but particularly the last, these IBSMs were confronted with a politics of preservation, whereby countermovements sought to limit or roll back legal protections won or sought by the social movement. ${ }^{5}$ Each kind of politics offered opportunities for different kinds of constitutional arguments. The politics of protection most successfully invoked the First Amendment and the Due Process Clauses of the U.S. Constitution; the politics of recognition and remediation were most closely associated with the Equal Protection Clause; and the politics of preservation invoked arguments based upon constitutional federalism, separation of powers, and various libertarian doctrines.

The first part of this Article will survey the deployment of constitutional doctrine by each IBSM as it engaged in these politics of protection, recognition, and preservation. Its perspective will be that of the constitutional litigators acting on behalf of those social movements. ${ }^{6}$ Accordingly, I shall rely heavily on their own words and ideas, as expressed in appellate briefs and oral arguments, especially those in U.S. Supreme Court cases. What interests me most is how movement lawyers translated the problems and aspirations of women and minorities into constitutional discourse, and how their arguments fared.

The perspective of the second part will be that of the Justices of the Supreme Court, to whom these arguments were ultimately addressed. There, I shall explore the ways in which these social movements affected the evolution of constitutional doctrine. IBSMs and their countermovements brought constitutional litigation that required the Court to apply old constitutional texts and precedents to new circumstances, not just in a single case, but in a string of cases that ran like a chain novel whose audience shifted in the course of narration. Moreover, IBSMs transformed the normative context in which these

5. See William N. Eskridge, Jr., Channeling: Identity-Based Social Movements and Public Law, 150 U. PA. L. REV. 419, 468-91 (2001) [hereinafter Eskridge, Channeling] (giving a detailed development of this typology).

6. I make no claim that these lawyers or the institutions with which they were associated were "representative" of the people who constituted or benefited from their respective IBSMs. For my discussion of ideological debates among social movement lawyers, see Section III.C. 
cases were decided, either by linking the new cases with established norms or by persuading society and its judges to change the normative context in which social traits were evaluated. As to the latter, IBSMs have moved public norms away from understanding race, sex, and sexual orientation as malign variations toward understanding them as tolerable and (for race and sex) benign variations. Finally, as these social movements and countermovements have become institutionalized players in American constitutional litigation and politics, they have become ongoing constituencies for particular ways of thinking about certain provisions of the Constitution. Thus, the oxymoronic notion of "substantive" due process has become an established part of constitutional jurisprudence because of the importance of the privacy right to women and sexual minorities; waves of minority groups' politics of recognition have transformed the Equal Protection Clause from the last resort to the cutting edge of individual rights claims; and the First Amendment's imperialism in constitutional law owes much to its ability to protect speech and expressive activities most dear to traditionalists as well as gay people, pro-life protesters as well as pro-choice advocates, and racial segregationists as well as people of color. IBSMs and their allies did not single-handedly work these transformations, but they have provided impetus and then support for judges when they have moved in the direction of those stances.

The story of doctrinal transformation has occurred just as dramatically at less general levels as well. In the course of their litigation campaigns, social movement lawyers came up with a variety of innovative constitutional arguments for advancing their groups' goals. Some of them were accepted by the judiciary as a basis for new doctrinal rules or exceptions. Many of the Supreme Court's most radical doctrinal innovations in the last century were originally developed and pressed (often for decades) by social movement or countermovement lawyers:

- selective incorporation of criminal procedure rules in the Bill of Rights into the Due Process Clause, especially Fifth, Sixth, and Eighth Amendment rights (Section II.A.1-2);

- dialectical federalism, whereby federal courts not only monitor state courts in criminal cases, but also engage in a constitutional dialogue (Section II.A.3);

- the due process right of sexual privacy, protecting Americans against state direction of their intimate lives and feelings (Section II.B);

- the equal protection idea of presumptively suspect classifications that will trigger heightened judicial scrutiny of statutory distinctions (Section II.C.1), as well as a sliding scale for heightened scrutiny that also considers the importance (including the constitutional impor- 
tance) of the interests of groups disadvantaged by legislative distinctions (Section II.C.3);

- the relevance of legislative motivations in constitutional cases, especially equal protection ones (Section II.C.2);

- the notion that the death penalty constitutes cruel and unusual punishment (Section II.D);

- the erosion and displacement of the political question doctrine, and its demise in voting cases (Section II.E.1);

- the expansion of congressional authority to enforce the Reconstruction amendments (Section II.E.2);

- the creation of a liberalized state action doctrine, including attribution of responsibility to the state for some actions by private parties and corporations (Section II.E.3);

- the extension of the First Amendment speech and assembly protection to expressive conduct and expressive association (Section II.F.1), and to sexual speech (Section II.F.2); and

- the anti-subordination principle as a way to ameliorate free speech/equal protection clashes (Section II.F.3).

Judges adopting these constitutional transformations have usually not accepted the IBSM perspective uncritically or without amendment, however. Judges have rejected the most radical proposals, such as a bar to the death penalty, and have diluted other proposals, such as a robust de novo review of state criminal convictions by federal judges, an anti-subordination reading of the Equal Protection Clause, and strong First Amendment protection for sexual speech. Even when judges have accepted IBSM constitutional visions and doctrines, the constitutional transformations movement lawyers argued for have had limited utility for actual minority group members. Some IBSMinspired doctrines have been turned to the advantage of countermovements. Examples include heightened scrutiny for suspect classifications, which has discouraged open affirmative action measures, and the First Amendment rights of expressive conduct and association, which now protect enclaves of exclusion against state antidiscrimination laws.

The fate of particular proposals and doctrines has depended on context, but one rule stands out: judges are rarely willing to insist on massive transfers of social or economic entitlements in American society, and when they have - as with school desegregation and abortion - they have been incompletely successful. This rule owes much to the institutional limits of the federal judiciary. Judges do not have the resources to undertake initiatives requiring administrative capacity, nor do they have the political legitimacy to engage in much activism not otherwise acceptable to the political system. When, by historical acci- 
dent, the Supreme Court was willing to press for redistribution of status and state resources in a number of arenas (1962-69), the political system responded with the elections of Richard Nixon and Ronald Reagan, who appointed Justices who were more institutionally cautious or even hostile to IBSM claims. Nonetheless, it is remarkable that the Burger Court - constituted to go slowly on race matters engaged in significant activism responding to the women's movements and that the Rehnquist Court - constituted to roll back affirmative action and abortion - has opened up the U.S. Constitution to lesbigay people.

In the third part of this Article, I maintain that IBSMs have also contributed to meta-developments in constitutional theory and discourse. Social movement lawyers, by and large, were not legal philosophers, but their work from the field has been fodder for three different stories about American constitutionalism in the last century; each story illustrates the continuing insights of legal realist, legal process, and critical theories of jurisprudence. Thus, consistent with legal realists' predictions, none of the foregoing areas of law developed in ways that would have been predictable from the original intent animating the constitutional provisions or from the precedents existing in 1900. The Supreme Court interpreted all of these constitutional provisions highly dynamically during the twentieth century. IBSMs pioneered the idea of a Living Constitution and inspired and drove the Court's dynamic interpretations by bringing cases that required judges to consider new circumstances for the application of old principles, by motivating judges to reconsider old principles in light of new norms, and by changing the face of the judiciary itself. Dynamic constitutional interpretation has been the death of serious originalism and of Article $\mathrm{V}$ as a means for making fundamental changes to the Constitution.

In addition, IBSMs were the key impulse supporting a global shift in the way the Supreme Court applied the Constitution in the twentieth century. The shift was away from the structural Constitution of the founding generation and the vested property/contract rights Constitution of the Lochner era and toward the Carolene Constitution, which justified judicial activism along legal process lines. Under the Carolene Constitution, the role of the Court is to protect the integrity of the pluralist political process, and especially to check the political process' tendency toward self-perpetuation and persecution or suppression of minorities. This entails protecting despised minority groups against state Kulturkampfs, assuring groups that are able to organize themselves into mass movements that they will be integrated into the political process, and protecting traditionalists from excessive state burdens once a formerly subordinated minority has become part of the political mainstream. 
Finally, the inevitable disappointments of IBSMs in constitutional litigation has fueled a constitutional skepticism. ${ }^{7}$ Any viable IBSM ultimately demands full equality from the state (normative recognition that its defining trait is a benign variation) - but any substantial success will generate a countermovement seeking to preserve old forms or new enclaves of segregation (normative recognition that the minority's trait is malign or, at best, tolerable). Through most of the twentieth century, various movements and countermovements were evenly enough balanced, politically, to motivate judges to seek compromises. The typical compromise would recognize only some of the minority's rights or would decline to implement their rights as soon as the minority desired, or both. Although social movement moderates embraced these compromises on pragmatic grounds and even heralded them as "victories," the partiality and, sometimes, the emptiness of the victories has soured many women, people of color, and lesbigay people on constitutionalism as an enterprise or, more interestingly, on constitutionalism as defined by Supreme Court decisions. This has given rise to constitutional law drop-out as well as popular constitutionalism approaches. The mix of constitutional pragmatism, skepticism, and nihilism is the most ambiguous legacy of identity-based social movements for constitutional law in the twentieth century. Among other things, it is headed toward a possible showdown with a Supreme Court that is more aggrandizing today - partly as a result of its past glory in civil rights cases - than at any previous point in our history.

\section{CONSTITUTIONAL ARgumentS AND STRATEgIES DEPLOYED BY THREE TWENTIETH CENTURY IDENTITY-BASED SOCIAL MOVEMENTS}

By 1900, American statutory and common law not only pervasively discriminated against people of color, women, and sexual and gender minorities, but also guaranteed a social and legal structure that committed violence against these citizens. American constitutional law provided little protection against discrimination or violence. Because most of the discrimination and much of the violence was by state and local governments, the checks provided by federalism, national separation of powers, and the Bill of Rights (then considered applicable only to the federal government) did women and minorities no good. Surprisingly, the Reconstruction amendments, protecting people of color against state government oppression, had shown few teeth for these groups. Although the Supreme Court construed the Thirteenth Amendment to protect people of color against state peonage ar-

7. See Robin West, Constitutional Skepticism, 72 B.U. L. REv. 765 (1992) [hereinafter West, Constitutional Skepticism]. 
rangements ${ }^{8}$ and the Fourteenth Amendment to protect them against blatantly discriminatory "class legislation," the Court also ruled that these amendments permitted the state to require racial segregation in railroad cars and public schools ${ }^{10}$ and to impose voting rules that effectively barred almost all people of color from the franchise. ${ }^{11}$ Laws excluding women from professions and the franchise had from the beginning been upheld against Fourteenth Amendment attack. ${ }^{12}$ People of color and feminists in the late nineteenth century did resist their second-class citizenship, but the Supreme Court rejected their constitutional claims and vision. ${ }^{13}$ Laws criminalizing sodomy or the "crime against nature," lewd behavior, the promulgation of indecent books or plays or movies, the depiction of sexual inversion, public indecency, and cross-dressing were not even subject to serious constitutional challenge at the turn of the twentieth century. ${ }^{14}$

As I have argued elsewhere, the existence of pervasive state exclusion, discrimination, and violence was a necessary factor in the formation of the civil rights, women's, and gay peoples' mass social movements. For each movement, the law was critical in creating a social identity as "colored," female, or "homosexual"; the subordinate social role reinforced by law was uncongenial to increasing numbers of women, gay people, and people of color as the nation urbanized, and courts were a natural forum for politically marginalized minorities to resist their subordination; legal actors and institutions were the scenes for traumatic encounters whose publicity transformed elite social movements into mass ones. ${ }^{15}$

\footnotetext{
8. Bailey v. Alabama, 219 U.S. 219 (1911).

9. Yick Wo v. Hopkins, 118 U.S. 356, 368 (1886); see also Strauder v. West Virginia, 100 U.S. 303, 308 (1879).

10. See Cumming v. Richmond County Bd. of Educ., 175 U.S. 528 (1899) (arguendo, public schools); Plessy v. Ferguson, 163 U.S. 537 (1896) (railroad cars).

11. See Giles v. Harris, 189 U.S. 475 (1903).

12. See Minor v. Happersett, 88 U.S. (21 Wall) 162 (1874) (holding that women have no right to vote); Bradwell v. Illinois, 83 U.S. (16 Wall) 130 (1873) (holding that women have no right to practice law).

13. For a striking analysis of the background to Plessy, that is, the political struggle by communities of color in post-Reconstruction Louisiana, see Rebecca J. Scott, Fault Lines, Color Lines, and Party Lines: Race, Labor, and Collective Action in Louisiana and Cuba, 1862-1912, in BEYOND SLAVERY: EXPLORATIONS OF RACE, LABOR, AND CITIZENSHIP IN POSTEMANCIPATION SOCIETIES 61, 65-83 (Frederick Cooper et al. eds., 2000).
}

14. On the emergence of visible communities of "inverts," "fairies," "prostitutes," and other gender-benders in the late nineteenth and early twentieth centuries, and their constitutional helplessness, see William N. EsKRIDGE, JR., GAYLAW: CHALlenging THE APARTHEID OF THE CLOSET ch. 1 (1999) [hereinafter ESKRIDGE, GAYLAw].

15. See Eskridge, Channeling, supra note 5, at $423-59$ (2001). 
With African Americans leading the way, each group formed institutions of resistance, critique, and normative aspiration. ${ }^{16}$ Initially, and before there was mass mobilization, the dominant (but not the only) public goal of those institutions was a politics of protection, urging that governmental authorities ought not be able to deploy the apparatus of the state to control the bodies and lives of women and minority peoples. The normative goal of such a politics was to persuade the mainstream that the group-defining trait (color, sex, sexual or gender orientation) was a tolerable variation from the norm and that stigmatized persons ought to have minimal rights. Generally, minority leaders in this phase did not contest the propositions that whiteness, maleness, and heterosexuality were the norm and that color, femininity, and homosexuality merited less social esteem. If the social group was able to show political strength, however, its organizational leaders would move toward a public stance which denied the inferiority of the group's defining trait: there is no material difference between blacks and whites, except those created by society and law; women can perform any social role that men can; gay is as good as straight.

Once this step was taken, the ISBM was engaged in a politics of recognition, demanding full respect and equal rights within the polity. To the extent this politics was successful in changing traditional laws and social attitudes, it was succeeded by a politics of remediation, whereby the group would seek state correction and even restructuring to "cure" the effects of past discrimination. IBSMs' politics of recognition and remediation inevitably triggered a politics of preservation. There, a countermovement would reassert traditional normative and legal baselines and the inferiority of the minority group. Such a politics might ease up if the minority gained acceptance within the nation's social and political pluralist system; although extremists would still insist on traditional baselines and the minority's inferiority, moderates in the countermovement would concede toleration of the minority, but with social and legally protected space for traditional ingroup members to retain their dominance.

For each kind of politics, the social movement's political arguments were translated into constitutional arguments. Even though the doctrinal bases for such arguments did not exist in 1900, movement lawyers ran various doctrinal trial balloons through the century. Many of them were embraced by judges. Although the doctrinal story could have evolved in a variety of different ways, it evolved in the following

16. The model in this paragraph is most obviously applicable to the experience of African Americans, women, and lesbigay people (the IBSMs which are the focus of this Part), but is also applicable to other IBSMs that are not my focus here: Asian and Hispanic Americans, people with disabilities, and (to a lesser extent) poor people. I shall take up issues raised by these social movements in the next part of the Article. 
thematically sensible way: IBSMs' libertarian politics of protection was confirmed and developed under the banner of the Due Process Clause's protection of "liberty" and the First Amendment's protection of speech, press, and assembly; their egalitarian politics of recognition and remediation gravitated to the Equal Protection Clause; their adversaries' arguments grounded on concepts of localism, majoritarian attachment to tradition, and liberty found voice in constitutional federalism, separation of powers, and freedom of speech and association.

\section{A. The Civil Rights Movement}

The defining experience for IBSMs in the United States has been that of African Americans, the social group most violently oppressed, most dramatically resistant, and most tragically unsuccessful. The normative triumph of the civil rights movement was the greatest yet most incomplete. Its story is told in riveting detail by a number of authors. ${ }^{17}$ All I wish to accomplish here is to show how the movement's lawyers - Moorfield Storey, William Hastie, Charles Houston, Thurgood Marshall, Spottswood Robinson, Constance Baker Motley, Jack Greenberg, Julius Chambers - translated the social, moral, and political goals of the movement into constitutional discourse.

At the outset, three points bear emphasis. First, my survey focuses on the dialogue between civil rights lawyers and judges. The more complex and internally debated normative goals of the social movement itself are secondary to my project, although they are of overriding importance to the larger history of the civil rights movement. Second, the lawyers bringing constitutional cases and arguing constitutional appeals did not "represent" all people of color in the United States; they represented particular organizations which reflected particular stances within communities of color (NAACP) and within the larger society (ACLU). To the extent that the NAACP's lawyers presented an "integrationist" agenda through constitutional attacks on apartheid, they were advancing a norm that was controversial within the African-American community and were deploying a strategy that they themselves realized was incomplete. ${ }^{18}$ Third, I am

17. The classic accounts are DAVID J. GARROW, BEARING THE CROSS: MARTIN LUTHER KING, JR., AND THE SOUTHERN CHRISTIAN LEADERSHIP CONFERENCE (1986) [hereinafter GaRRow, BEARING THE CROSS]; RICHARD KLUGER, SiMPLE JUSTICE: THE HISTORY OF BROWN $V$. BOARD OF EDUCATION AND BLACK AMERICA'S STRUGGLE FOR EQuality (1976); Aldon D. MORRIS, The ORIGINS OF THE CIVIL Rights MOVEMENT: BLACK COMMUNITIES ORGANIZING FOR CHANGE (1984). For a briefer and more popular account, see Adam FaIRClOUgh, BeTter DAy COMING: BLACKS AND EQUALiTy 18902000 (2001).

18. Contrast the NAACP's integrationist and pragmatic philosophy with the more confrontationalist philosophy of organizations such as the International Labor Defense, a radical class-based organization in the 1930s, the Civil Rights Congress in the 1940s, and the 
presenting their constitutional politics as a progression of what was the primary - but not necessarily the only - goal of the social movement at different points in time: so long as black people were politically impotent in this country, the lawyers mainly sought protection for those in their group most brutalized by the state. Once blacks became more politically and socially significant, the lawyers made recognition and then remediation the overriding item on their agenda, which triggered overt counter-organization by traditionalists insisting on preservation. ${ }^{19}$

\section{The Politics of Protection, 1913-40}

Notwithstanding the regime of apartheid that settled over much of the nation between 1890 and 1910, many people of color rejected the notion that their race was "inferior" (as apartheid claimed) - and almost all people of color rejected the violence African Americans suffered at the hands of private and public actors. Founded in 1909 by a biracial collection of persons, the National Association for the Advancement of Colored People ("NAACP") sought to refute erroneous stereotypes about black people and to protect blacks against public and private violence (especially lynching), loss of their rights to vote, and denial of housing where they could flourish. ${ }^{20}$ From its beginning, the NAACP involved itself in cases where black people's liberties were threatened by the state (or by private actors usurping state roles). The first case in which the Association became involved arose out of the capital conviction of a black man, Pink Franklin, for killing a police officer while resisting arrest for violating the state peonage law. The NAACP arranged for counsel to take Franklin's case to the

Student Nonviolent Coordinating Committee of the 1960s; with the economic boycott and protest strategy for reform by grass-roots mobilization reflected in the Southern Christian Leadership Conference of the 1950s and 1960s; and with the black nationalist (separatist) philosophy of the Nation of Islam in the 1960s. All of these groups spoke for many blacks in America, and all sought to change attitudes and laws, but only the NAACP and likeoriented groups (the ACLU, the Committee for Civil Rights Under the Law) regularly spoke for blacks to the Supreme Court in constitutional cases.

19. That there was this kind of rough progression in the lawyers' presentation and, perhaps, in the priorities of the social movement does not mean that recognition was not important to many minorities during the early stages; that protection did not remain critically important even after the politics of recognition became predominant; or that preservation was not strongly favored by most people in the majority throughout the whole period. That the various politics I describe are overlapping should not obscure my central point, which is that the public debate stimulated by the civil rights movement went through discernible stages of political and constitutional presentation.

20. On the founding of the NAACP, see 1 CHARLES Flint KEllogG, NAACP: A History of THE NATIONAL ASSOCIATION OF COLORED PEOPLE 9.45 (1967); DAVID LEVERING LEWIS, W.E.B. DUBOIS: BIOGRAPHY OF A RACE 1868-1919 (1993) (biography of an important founding member); JAMES M. MCPHERSON, THE ABOLITIONIST LEGACY: FROM RECONSTRUCTION TO THE FOUNDING OF THE NAACP (1975); MARY WARE Ovington, THE Walls CAME Tumbling DOWN (1947) (giving a first-person account). 
Supreme Court. Although the peonage statute was a blatant violation of the Thirteenth Amendment, the Court denied Franklin's poorly articulated constitutional appeal that this should have affected his murder conviction. ${ }^{21}$ After this disappointing debut, the NAACP established a formal legal committee that regularly handled or coordinated cases where the liberties - and typically the lives - of African Americans were threatened.

Thus, most of the NAACP's early cases involved criminal prosecutions against black men. ${ }^{22}$ Some of these were little more than mobinspired lynchings railroaded through the legal process. ${ }^{23}$ Moore $v$. Dempsey, ${ }^{24}$ an early and important example, involved a habeas appeal of the death sentences meted out to six of the black men convicted in Phillips County, Arkansas for the asserted murder of a white man. His death occurred in the wake of a spree of murders of black men by a hysterical white mob during the Red Summer of 1919. The NAACP presented the Supreme Court with a detailed factual record which showed the outrageous setting of the case: more than 200 blacks were slaughtered without a single indictment, while the death of one white man called forth seventy-nine black scapegoats without credible evidence of their guilt; once arrested, the black men were beaten and tortured by the authorities until some agreed to testify against others; twelve of the remaining defendants were railroaded through a "trial" in which they were perfunctorily represented by an appointed counsel who did not consult them and were convicted by an all-white jury which deliberated for two to three minutes before reaching the verdict of guilty and a penalty of death. ${ }^{25}$ The only evidence against the defendants was that extracted by torture, and the whole climate was tainted by news reports that they were leaders of an insurrection and by mobs of white men surrounding the courtroom and poised to lynch

21. Franklin v. South Carolina, 218 U.S. 161, 170-72 (1910). Eight months later, the Court invalidated an Alabama peonage law similar to the one that indirectly brought the death penalty (later commuted to life in prison) to Pink Franklin. See Bailey v. Alabama, 219 U.S. 219 (1911). See generally Benno C. Schmidt, Jr., Principle and Prejudice: The Supreme Court and Race in the Progressive Era, Part 2: The Peonage Cases, 82 Colum. L. REv. 646 (1982).

22. See KELLOGG, supra note 20 , at 64 .

23. An NAACP study documented 3,224 lynchings between 1889 and 1918. See id. at 210. See generally id. at 209-46 (detailing anti-black violence in the 1910s and the NAACP's legislative and publicity campaign against lynching).

24. 261 U.S. 86 (1923); see also infra Section II.A infra (discussing Moore).

25. See Petition for Writ of Habeas Corpus, reprinted in Record on Appeal at 1-11, Moore v. Dempsey, 261 U.S. 86 (1923) (1922 Term, No. 199); Brief for Appellants at 1-33, Moore (1922 Term, No. 199) (Moorfield Storey, counsel for appellants); RICHARD C. CORTNER, A MOB INTENT ON DEATH: THE NAACP AND THE ARKANSAS RIOT CASES 5105 (1988) (providing a detailed account of the riots, the arrests and trials, and the early involvement of the NAACP in defending the men). 
them if the verdict had been otherwise than death. Defendants' claim was that because of the outside "mob domination," the "entire trial, verdict, and judgment against them was but an empty ceremony," its resulting death penalty nothing but "judicial murder.," ${ }^{26}$ Given such a damning factual record, the Court agreed, holding that such a trial, "hurried to conviction under the pressure of a mob without any regard for... [the defendants'] rights and without according to them due process of law [was void]."27

The Phillips County case was one of the NAACP's greatest triumphs. It was the first of a series of cases where the NAACP not only sought to protect innocent black defendants, but also sought judicial recognition of due process rules that would inure to the benefit of all black defendants. In Brown v. Mississippi ${ }^{28}$ for example, the Supreme Court overturned three convictions based on confessions obtained by whipping and physical torture. The Court's opinion established as an enduring principle of its due process jurisprudence that compelled confessions cannot be the basis for state court convictions and held that federal courts will enforce this rule even when not timely raised in the state courts. ${ }^{29}$ Moore was also a harbinger of the famous Scottsboro cases, where the NAACP's role was only a supporting one ${ }^{30}$ The cases arose in 1931 out of alleged rapes of two white women by nine black youths hitching rides on railway cars in Jackson County, Alabama. Mindful that a proceeding as openly mob-driven as that in Moore would trigger federal intervention, the newspapers and the authorities discouraged mobs from forming. Nor was there indication that the accused were tortured, as there would be in other cases. There was still plenty of evidence that the defendants were railroaded to guilty verdicts, with death sentences. As Samuel Liebowitz's Supreme

26. Record on Appeal at 6-7, Moore (1922 Term, No. 199); Brief for Appellants at 33, Moore (1922 Term, No. 199).

27. Moore, 261 U.S. at 87 . The actual disposition of the case was a remand to the federal trial court to hold a hearing to determine whether the asserted facts were correct; if so, habeas would be granted. Before the trial court decided the matter, the Governor commuted the six men's death sentences to short prison terms. By 1925, all of the sixty-seven men who had been sentenced to prison for unproven roles in the single white man's death had been released. KELLOGG, supra note 20, at 244.

28. 297 U.S. 278 (1936); see also Section II.A.1 (discussing Brown); RICHARD C. CORTNER, A "SCOTTSBORO" CASE IN MISSISSIPPI: THE SUPREME COURT AND BROWN $v$. MISSISSIPPI (1986) [hereinafter CORTNER, A "SCOTTSBORO" CASE IN MISSISSIPPI].

29. Brown, 297 U.S. at 285-87.

30. Although the NAACP procured lawyers for the "Scottsboro boys," the Communistaffiliated International Labor Defense won their Supreme Court cases with the excellent representation of Samuel Leibowitz. See generally Hugh T. Murray, Jr., The NAACP versus the Communist Party: The Scottsboro Rape Cases, 1931-32, in THE NEGRO IN THE DEPRESSION AND WAR: PRELUde to ReVOlution, 1930-1945, at 276 (Bernard Sternsher ed., 1969). 
Court brief for the Scottsboro defendants maintained, the cases were like Moore in that the evidence of guilt was slim and suspect; the defendants were not afforded their choice of counsel and were essentially unrepresented; and people of color were excluded from serving on the jury. ${ }^{31}$ In Powell v. Alabama,${ }^{32}$ the Court reversed the defendants' convictions on the ground that they were denied due process, which the Court interpreted to require effective representation by counsel before defendants could be sentenced to death for conviction of a capital crime. The defendants were retried and re-convicted, but the trial judge (remarkably) overturned their convictions on the ground that the testimony of their accuser was incredible. Some of them were tried and convicted yet again.

In Norris v. Alabama ${ }^{33}$ the Supreme Court reversed these third capital convictions, on the ground that the state had violated the Equal Protection Clause by effectively excluding people of color from the juries. Norris was the first case in which the Supreme Court overturned a criminal conviction on grounds of exclusion of blacks from the juries without any admission to that effect by state officials or judges. ${ }^{34}$ Chief Justice Hughes' opinion for a unanimous Court carefully examined the evidence presented (and probably fabricated) by the local officials, and found that it did not rebut the prima facie case of discrimination made out by the utter absence of black people on juries in Jackson County, Alabama "within the memory of witnesses who had lived there all their lives." ${ }^{35}$ This precedent proved fruitful for the NAACP as a weapon to challenge death sentences for people of color convicted in southern jurisdictions where blacks had long been excluded de facto from jury service. Not only did the Supreme Court overturn convictions of a number of black defendants on this ground, ${ }^{36}$ but the Fifth Circuit enforced Norris in the 1940s and 1950s, sending

31. See Brief for Petitioners at 36-62, Powell v. Alabama, 287 U.S. 45 (1932) (1931 Term, Nos. 98-100). See generally DAN T. CARTER, SCOTTSBORO: A TRAGEDY OF THE AMERICAN SOUTH (rev. ed. 1969); JAMES GOODMAN, STORIES OF SCOTTSBORO (1994).

32. 287 U.S. 45 (1932); see also infra Section II.A.1.b (discussing Powell).

33. 294 U.S. 587 (1935); see also infra Section II.A.1.c (discussing Norris).

34. See Benno C. Schmidt, Jr., Juries, Jurisdiction, and Race Discrimination: The Lost Promise of Strauder v. West Virginia, 61 TExAS L. REV. 1401 (1983) [hereinafter Schmidt, Juries]. Compare Neal v. Delaware, 103 U.S. 370 (1881) (holding that state cannot exclude people of color from juries as a matter of law; admission of race discrimination by officials meets this test), with Thomas v. Texas, 212 U.S. 278 (1909) (rejecting race discrimination claim because state courts had found insufficient proof of such discrimination).

35. Norris, 294 U.S. at 591.

36. See Hill v. Texas, 316 U.S. 400 (1942); Smith v. Texas, 311 U.S. 128 (1940); Pierre v. Louisiana, 306 U.S. 354 (1939); Hale v. Kentucky, 303 U.S. 613 (1938); Hollins v. Oklahoma, 295 U.S. 394 (1935). See generally Douglas L. Colbert, Challenging the Challenge: Thirteenth Amendment as a Prohibition Against the Racial Use of Peremptory Challenges, 76 CORNELL L. REV. 1, 83 (1990). 
an important message to southern jurisdictions that whites-only jury policies were costly. ${ }^{37}$ Norris also saved the remainder of the Scottsboro defendants from death sentences - except (ironically) Clarence Norris, who was convicted in a fourth trial. His death sentence was later commuted, and he emerged from prison in 1950, having lost almost twenty years of his life for what is now considered "the most notorious racial hoax case in our history." 38

The jury cases reflected a broader challenge: knowing that open exclusion of black people by law might be held to violate the Equal Protection Clause, southern officials devised subterfuges that weeded out blacks from jury lists de facto. ${ }^{39}$ They did the same thing with voting: knowing that open exclusion of black people by law might be held to violate the Fifteenth Amendment, southern officials found ways to discourage or exclude blacks from voting lists indirectly. As in the jury cases, the NAACP's strategy was to document the dearth of black people on voting lists and to show how white officials accomplished their exclusion. Indeed, the NAACP's first Supreme Court amicus brief was in a voting case, Guinn $v$. United States. ${ }^{40}$ Oklahoma required that citizens pass a literacy test in order to vote; exempted from the test were people who or whose ancestors were entitled to vote in 1866 , just before the Fourteenth and Fifteenth Amendments were adopted. The NAACP's Moorfield Storey argued that this law effectively debarred most people of color from voting because they could not read, without imposing the same disability on illiterate whites, whose ancestors were voters in 1866 . The Supreme Court ruled that a literacy test standing alone was permissible, but its joinder with a grandfather clause violated the Fifteenth Amendment's requirement that the right to vote not be "denied or abridged... on account of race, color, or previous condition of servitude." "Gi1 Guinn would seem like an easy case - but only to today's eyes. During the "progressive" era, it was a rather bold decision because it analyzed the state law in terms of its

37. See John Andrew Martin, The Fifih Circuit and Jury Selection Cases: The Negro Defendant and His Peerless Jury, 4 HouSTON L. REV. 448 (1966).

38. Katherine K. Russell, The Racial Hoax as Crime: The Law as Affirmation, 71 IND. L.J. 593, 598 (1996).

39. In Norris, for example, the local officials testified that no people of color were qualified to serve on juries; the NAACP produced black men who were obviously well-qualified, and the Supreme Court refused to credit the officials" "sweeping characterization of the lack of qualifications." 294 U.S. at 599. Additionally, Norris's lawyers demonstrated to the Court that officials had tried to cover up their discrimination by adding black names to the rolls after the lawsuit was brought. See Schmidt, Juries, supra note 34, at 1479.

40. 238 U.S. 347 (1915); see also infra Section II.E.1 (discussing Guinn). See generally Benno C. Schmidt, Jr., Principle and Prejudice: The Supreme Court and Race in the Progressive Era, Part 3: Black Disenfranchisement from the $K K K$ to the Grandfather Clause, 82 Colum. L. REV. 835 (1982) [hereinafter Schmidt, Principle and Prejudice].

41. Guinn, 238 U.S. at 362. 
practical application. The decision was only "rather" bold, because Oklahoma's scheme was more transparent than that followed in any other state, because the Court approved the use of literacy tests generally, and because even Oklahoma evaded the Court's mandate with a new grandfather clause for two decades..$^{42}$ Guinn did not assure that people of color would be able to vote in the South. There were as many subterfuges as there were voters of color.

Deterred by Guinn from directly barring people of color from voting in general elections, several southern states barred them from participating in the Democratic Party primary, where electoral decisions were effectively made. The NAACP challenged the Texas statute instantiating a whites-only primary. Although the Supreme Court had ruled that primaries were not "elections" that Congress could regulate under Article I, section 4 and had suggested that voting practices might be political questions, Storey urged the Court to recognize the Texas statute as a "flagrant, unjust discrimination against a citizen solely on account of race and color." ${ }^{, 43}$ Following Guinn and essentially ignoring the earlier precedents, the Supreme Court ruled in Nixon v. Herndon $^{44}$ that the Fourteenth Amendment prevented Texas from excluding blacks in primary elections. Texas responded by ceding authority over primaries to the State Democratic Convention of Texas, which maintained that it was not a state actor accountable under the Fourteenth and Fifteenth Amendments. The NAACP challenged this scheme as an unconstitutional subterfuge, ${ }^{45}$ but the Supreme Court permitted the practice in $1935 .{ }^{46}$

The NAACP got a second shot at the issue after the reconstituted New Deal Court ruled in United States v. Classic ${ }^{47}$ that interference with the right to vote in a primary involves a right "secured or protected by the Constitution and laws of the United States." Arguing

42. See Lane v. Wilson, 307 U.S. 268 (1939) (invalidating Oklahoma's next voting law, which gave people of color eleven days in May 1916 to register or suffer permanent loss of their franchise).

43. Brief for Plaintiff-in-Error at 31, Nixon v. Herndon, 273 U.S. 536 (1927) (1926 Term, No. 117) (distinguishing Newberry v. United States, 256 U.S. 232 (1921), stating that Congress's power to prescribe the manner for holding "Elections" for its members does not include authority over primaries); Reply Brief for Plaintiff-in-Error at 19-23, Nixon (1926 Term, No. 117) (distinguishing Giles v. Harris, 189 U.S. 475 (1903) and refusing to entertain claim for injunction in voting rights case).

44. 273 U.S. 536 (1927); see also infra Sections II.C.1 and II.E.1 (discussing Nixon).

45. Brief on the Merits [for the Petitioner] at 12-19, Grovey v. Townsend, 295 U.S. 45 (1935) (1934 Term, No. 563).

46. The Supreme Court initially declined to accept the state's claim that the Democratic Party rather than the state was responsible for the exclusion, Nixon v. Condon, 286 U.S. 73 (1932), but once that matter was clarified the Court ruled that the state was no longer responsible. Grovey v. Townsend, 295 U.S. 45 (1935).

47. 313 U.S. 299 (1941). 
that the Texas white primary set-up was a patent effort to disenfranchise people of color and that Classic required the state to be held responsible, the NAACP, joined now by the ACLU, persuaded the Court to overrule the earlier precedent in Smith v. Allwright. ${ }^{48}$ This decision, handed down in 1943, had more tangible consequences than the Court's earlier decisions. Only three percent of southern blacks were registered to vote in 1940 , but twenty percent were registered by 1952 - in part due to the NAACP's post-Allwright litigation campaign against white primaries and the willingness of judges to enforce Allwright broadly. ${ }^{49}$ The voting cases, even more than the mob pressure and the jury cases, pressed the Court to look beneath the formally neutral rules and find the underlying exclusionary project for which the state bore responsibility.

By the time the NAACP was founded, apartheid was wellestablished in the South, and it probably would have been futile to challenge it in the period before World War II, especially given the Association's limited resources. But the NAACP was alert to local efforts expanding the reach of legal segregation of the races. It was not until 1910 that a major city (Baltimore) legally restricted black people to residing in designated ghettoes. ${ }^{50}$ The Baltimore branch of the NAACP thrice challenged the 1910 ordinance and its two successors as a violation of the Due Process Clause. Twice the Maryland Court of Appeals invalidated the ordinance; it held the third appeal pending the NAACP's challenge to a similar Louisville ordinance before the Supreme Court. ${ }^{51}$ Moorfield Storey's brief in the Louisville case maintained that the ordinance invaded vested property rights in violation of the due process, equal protection, and privileges and immunities clauses of the Fourteenth Amendment. He distinguished Plessy and the public school cases, where:

it is possible to say that no harm is suffered through the separation of the races, if the facilities enjoyed by either race are the same as those enjoyed by the other. In the case at bar, no such argument can be made, because every parcel of land has qualities peculiar to itself .... One of the

48. 321 U.S. 649 (1943) (overruling the Court's unanimous opinion in Grovey). The Court followed and extended Allwright in Terry v. Adams, 345 U.S. 461 (1953) (the Jaybird case, where the Court invalidated yet another elaborate subterfuge to disenfranchise black voters). See also Section II.E.3 (discussing Terry).

49. See, e.g., Mitchell v. Wright, 154 F.2d 924 (5th Cir. 1946); Dean v. Thomas, 93 F. Supp. 129 (E.D. La. 1950); Adams v. Whittaker, 195 S.W.2d 634 (Ark. 1946). See generally J. Morgan Kousser, COLORblind INJUSTICE: MinORITY Voting RIGHTS AND THE UNDOING OF THE SECOND RECONSTRUCTION (1999).

50. See Garrett Power, Apartheid Baltimore Style: The Residential Segregation Ordinances of 1910-1913, 42 MD. L. REV. 289 (1983); R.L. Rice, Residential Segregation by Law, 1910-1917, 34 J. SO. HIST. 179 (1968).

51. See Kellogg, supra note 20, at 184; George C. Wright, The NAACP and Residential Segregation in Louisville, Kentucky, 1914-1917, 78 REG. KY. HIST. SOC. 39 (1980). 
first essentials of a free government is the right of every citizen to establish his residence where he sees fit and to move from place to place at pleasure. Such an ordinance as that now in question does not affect simply the convenience and comfort of those citizens to whom it applies, but strikes at their right to live at all. ${ }^{52}$

Storey closed his brief with a bold echo of Justice Harlan's dissenting opinion in Plessy, charging that the innovative ordinance would "provoke conflict between the races and [could] reduce negro citizens to a position of inferiority." cus brief filed by Wells $H$. Blodgett and Frederick Lehmann, American Bar Association moguls who insisted "strenuously ... upon a single and undivided American citizenship - no hyphens." ${ }^{54}$ Innovations such as the Louisville ordinance would generate a spiral of race animosity, for " $[\mathrm{t}]$ he prejudice of race grows by what it feeds upon. Its appetite is insatiable." 55

Deciding Buchanan v. Warley, ${ }^{56}$ the Supreme Court agreed, refusing to extend Plessy to permit legally required residential segregation. Because the ordinance destroyed the right of the individual to acquire, enjoy, and dispose of his property, it violated the Due Process Clause. Justice Day's opinion for the Court did not follow the radical rhetoric of the NAACP briefs, nor did it actually protect people of color against housing discrimination. After Buchanan, segregationists relied on discriminatory zoning ordinances and racially restrictive covenants in leases to preserve racially segregated housing patterns. Defending a white homeowner wanting to sell to a black purchaser in the District of Columbia, the NAACP challenged racially restrictive covenants as inconsistent with Buchanan. The District's court of appeals upheld an injunction against the sale. The Supreme Court dismissed the appeal in Corrigan v. Buckley, ${ }^{57}$ with a written opinion ruling that the Equal Protection Clause is applicable to public but not private discrimination; hence, the discriminatory terms of the owner's lease were not constitutionally reviewable. The Court did not address the NAACP's argument that a judicial decree enforcing the racially restrictive cove-

52. Brief for Plaintiff in Error at 35-36, Buchanan v. Warley, 245 U.S. 60 (1917) (1915 Term, No. 33).

53. Id. at 44 .

54. Brief of Amici Curiae Wells H. Blodgett and Frederick W. Lehmann at 7, Buchanan v. Warley, 245 U.S. 60 (1917) (1915 Term, No. 33).

55. $I d$, at 8 .

56. 245 U.S. 60 (1917); see also infra Section II.C.1 (discussing Buchanan).

57. 271 U.S. 323 (1926). Even after Corrigan, the Court continued to apply Buchanan's rule against ordinances requiring housing segregation. E.g., Harmon v. Tyler, 273 U.S. 668 (1927) (affirming lower court decision invalidating ordinance requiring consent of a majority of community homeowners before a black person could establish a home there); Richmond v. Deans, 281 U.S. 704 (1930) (similar). 
nant was state action, on the ground that the issue was not properly presented on appeal. Although the Supreme Court would later revisit the constitutional status of racially restrictive covenants, state and federal courts read Corrigan as placing racially restrictive covenants beyond the scope of the Fourteenth Amendment. ${ }^{58}$ Such covenants were widely deployed, and residential segregation was the practical result almost everywhere in the United States.

From the NAACP's point of view, the greatest price of Plessy was segregated education. The Association believed that opportunities for black people could not be realized without education and literacy. Most of its early efforts focused on publicizing the poor quality of education for blacks in the South and lobbying for funds to remedy that, ${ }^{59}$ but in the early 1930 s the NAACP challenged the inadequate resources through constitutional litigation. Between 1933 and 1950, the Association brought or supported litigation to desegregate graduate and professional schools and to equalize the salaries and facilities in white and black primary and secondary schools..$^{60}$ As to the latter, litigation was most successful when a strong attorney was in charge of the cases and had the support of a well-organized black community and a potentially receptive community of white moderates. The classic success story was Thurgood Marshall's work with the community in Maryland, a moderate state in racial politics. ${ }^{61}$ As to the former, the NAACP maintained that states offering black citizens no graduate school opportunities - not even meaningful separate ones - was open discrimination that even Plessy did not justify. ${ }^{62}$ Charles Houston litigated a number of these cases, and won a significant victory in Missouri ex rel. Gaines $v$. Canada. ${ }^{63}$ The NAACP's brief objected to the state's complete exclusion of blacks from its professional schools and documented their under-representation as a systematic problem in the South. The Supreme Court agreed. After this victory, the NAACP established a separate NAACP Legal Defense and Educa-

58. See Clement E. Vose, Caucasians Only: The Supreme Court, the NaACP, AND THE RESTRICTIVE COVENANT CASES 19 (1959); id. at 22-24 (Corrigan was consistent with the liberty of contract ideology of the era).

59. See KELLOGG, supra note 20, at 187-99.

60. Mark V. Tushnet, The NAACP's Legal Strategy Against Segregated EDUCATION, 1925-1950, at 34 (1987). Tushnet's account of the education litigation is a less triumphalist interpretation than that in what is still the main authority, KLUGER, supra note 17.

61. See TUSHNET, supra note 60 , at 34-69.

62. See McCabe v. Atchison, Topeka \& Santa Fe Ry., 235 U.S. 151 (1914) (invalidating an Oklahoma law excluding blacks from dining and sleeping cars, without providing comparable accommodations of any sort).

63. 305 U.S. 337 (1938); see TUSHNET, supra note 60, at 70-81 (providing an account of this litigation). 
tional Fund, Inc. ("Inc. Fund"), which pressed the Association to a new level of constitutional discourse.

\section{The Politics of Recognition and Some Remediation, 1940-72}

Although the NAACP's agenda in its early years was dominated by efforts to protect the lives, liberties, and property rights of African Americans against state-sanctioned violence and discrimination, the Association was also committed to "complete equality before the law" for people of color. ${ }^{64}$ This aspiration reflected a nascent, albeit littlefulfilled, politics of recognition. I view the 1930s as a transitional decade, during which that politics began to overtake the still-necessary politics of protection. The Texas primary cases, culminating in the triumph in Allwright, reflected this transition: the right to vote was important to assure that local politics would be even somewhat protective of black people's safety and needs, but was also symbolically important to both people of color and the judiciary. The full citizenship promised by the Reconstruction amendments was an empty promise without the franchise, and a democracy that formally excluded people because of their race looked more than a little like Nazi Germany.

The civil rights movement's shift from a politics of protection to a politics of recognition was formally made when the NAACP changed its constitutional stance toward apartheid. During the period described above, its lawyers pressed constitutional arguments from within the Plessy framework, whereby the state had no obligation to correct social prejudice or force unwilling whites to associate with blacks, but did have an obligation not to be a conduit through which prejudiced whites could deprive blacks of their lives (Moore, Powell), fundamental liberties (Norris), or property rights (Buchanan). Tangible even if limited gains accompanied and may have resulted in part from this litigation: new apartheid laws had been stopped in their tracks even as old ones remained in place; black literacy had soared to eighty percent and the black-white ratio of teachers' salaries had risen to sixty-five percent (the teacher salary cases); lynching and state execution of black people for crimes had fallen off significantly; blacks for the first time in the century were able to register and vote in primary and general elections. ${ }^{65}$ All of these gains were affected and generally accelerated by the nation's experiences in and around World War II. At this point, Plessy itself came under siege on all fronts.

64. Brief for Petitioner at 3, NAACP v. Alabama, 357 U.S. 449 (1958) (1957 Term, No.

91) (quoting the NAACP's articles of incorporation).

65. See TUSHNET, supra note 60, at 103 (teachers' salaries). 
In 1941, A. Philip Randolph and other prominent black leaders organized a March on Washington Movement ("MOWM") insisting that the federal government desegregate: if people of color were going to be asked to die for their country, their country was obliged to afford them equal dignity and respect. ${ }^{66}$ Gunnar Myrdal's An American Dilemma, published in 1944, rubbed America's public face in the hypocrisy of demonizing the Nazis as racist while practicing racial segregation at home. In the Japanese curfew and evacuation cases decided in 1943-44, the Supreme Court announced that race-based classifications were odious to a free people, even as the Justices upheld racebased liberty deprivations against Japanese-American citizens (to vigorous critique after the war). ${ }^{67}$ At the urging of the Solicitor General, the Supreme Court interpreted the Railway Labor Act to bar racebased employment discrimination by railroad unions. ${ }^{68}$

World War II cemented the case against racist policies. Not only did Asian as well as African Americans serve valorously during the war, but whites as well as people of color noticed the incongruity of their returning to an apartheid society after fighting a war against "the apostles of racism." This was the term the NAACP used in its brief successfully urging the Supreme Court to strike down a state law requiring race segregation in interstate bus trips. ${ }^{69}$ The war also accelerated the demographic shift of blacks from the rural south to urban areas in the north. The NAACP's membership soared tenfold ${ }^{70}$ giving its leaders greater political credibility in national politics. To Secure These Rights, the 1947 report of President Truman's Committee on Civil Rights, called for "the elimination of segregation... from American life." $"$ In 1948, Truman issued an executive order requiring

66. In response to the movement, President Roosevelt issued Executive Order 8802, which prohibited race-based discrimination in federal government employment (but not in the armed services) as well as in defense industries doing business with the government. After the order, which was tepidly carried out, the MOWM fizzled. See FAIRCLOUGH, supra note 17 , at $152-59$.

67. See Korematsu v. United States, 323 U.S. 214, 216 (1944); Hirabayashi v. United States, 320 U.S. 81, 100 (1943); see also infra Section II.C.1 (discussing Korematsu).

68. Steele v. Louisville \& Nashville R.R., 323 U.S. 192 (1944).

69. Brief for Appellant at 28, Morgan v. Virginia, 328 U.S. 373 (1946) (1945 Term, No. 704); see [ACLU's] Motion for Leave to File Brief as Amicus Curiae and Brief in Support Thereof at 14-15, Morgan (1945 Term, No. 704) (arguing that race-based categories are inherently stigmatic in our society). The Supreme Court struck down the state law in Morgan v. Virginia. 328 U.S. 373 (1946). See also Mitchell v. United States, 313 U.S. 80, 97 (1941) (holding that forcing a black customer with a first-class ticket to ride second-class violates the Interstate Commerce Act).

70. FAIRCLOUGH, supra note 17, at 182 (NAACP membership went from 50,000 in 1940 to 500,000 in 1946).

71. To Secure These Rights: The Report of the President's Commission on CIVIL RIGHTS 166 (1947) (urging the elimination of racial segregation from the armed forces, public transport, housing, health care, and education). 
desegregation in the armed forces. Public norms had changed; support for state-imposed segregation outside the South was waning. In the same year as Truman's order, the NAACP's Board of Directors officially endorsed Thurgood Marshall's position that the Association "not undertake any case or cooperate in any case which recognizes or purports to recognize the validity of segregation statutes or ordinances ....".72

During the 1947 Term, Marshall pressed the NAACP's new position in Sipuel v. Board of Regents, ${ }^{73}$ another graduate school case. The Inc. Fund, for the first time, urged the Court to re-examine the separate but equal doctrine and overrule Plessy. ${ }^{74}$ Although the Court invalidated the state's program on the narrower ground that it was grossly unequal, the Justices were moving toward a renunciation of apartheid, albeit sensitive that they not be perceived as moving too precipitously or writing their opinions provocatively. ${ }^{75}$ Both the NAACP and the Court got a push from private litigants that same Term, when Shelley v. Kraemer ${ }^{76}$ presented the Court with the constitutionality of judicial enforcement of racially restrictive covenants in property contracts. At the urging of the NAACP, the Solicitor General filed an amicus brief invoking the report of the President's Committee on Civil Rights to support forceful judicial antidiscrimination rules and to criticize the destructiveness of housing segregation in particular. ${ }^{77}$ Abrogating the broad reading of Corrigan by most lower courts, the Supreme Court unanimously held that judicial enforcement of the covenants was state action violating the Equal Protection Clause. ${ }^{78}$ That the Court was willing to fill the doctrinal loophole left open in Buchanan was cheering to civil rights lawyers, encouraging them to press ahead with an anti-apartheid campaign that

72. TUSHNET, supra note 60 , at 115 (quoting resolution).

73. 332 U.S. 631 (1948).

74. Brief for Petitioner at 18-51, Sipuel v. Bd. of Regents, 332 U.S. 631 (1948) (1947 Term, No. 369).

75. See Dennis J. Hutchinson, Unanimity and Desegregation: Decisionmaking in the Supreme Court, 1948-1958, 68 GEO. L.J. 1, 4-13 (1979) (discussing Sipuel and several other race cases of the 1947 Term).

76. 334 U.S. 1 (1948); see also Section II.E.1 (discussing Shelley). See generally VosE, supra note 58, at 158-96 (providing a detailed examination of NAACP's and amici's arguments in Shelley); Louis Henkin, Shelley v. Kraemer: Notes for a Revised Opinion, 110 U. PA. L. REV. 473 (1962).

77. Brief of Amicus Curiae United States at 1-25, Shelley v. Kraemer, 334 U.S. 1 (1948) (1947 Term, Nos. 72, 87, $290 \& 291$ ) (arguing that the interest of the United States is in preventing racial ghettoes and an international image of apartheid); see also id. at 92-103 (arguing that the enforcement of racially restrictive covenants is contrary to the public policy of the United States).

78. Shelley, 334 U.S. at 14-18 (state action); id. at 18-23 (equal protection violation). 
clearly had the support of both the Solicitor General's Office ${ }^{79}$ and a growing number of amici. Fifteen amicus briefs supported the Inc. Fund in Shelley - many more than had ever been filed in any civil rights case before $1948 .^{80}$ Virtually sealing the case against apartheid, the Court in 1948 struck down two state laws discriminating on the basis of Asian race or ethnicity. ${ }^{81}$

Within the Court, the Justices were struggling to find the right strategy and the best pace for leading the country away from the racebased policies of apartheid. ${ }^{82}$ During the 1949 Term, the Court heard three NAACP challenges to state segregation. In two graduate school cases, the NAACP and supporting amici urged the Court either to overrule Plessy or to hold its principle inapplicable to public education. ${ }^{83}$ The United States filed amicus briefs in both cases questioning Plessy and insisting that it not be extended to public graduate education. ${ }^{84}$ In the NAACP's third case of the Term, Henderson v. United States, ${ }^{85}$ Solicitor General Philip Perlman (representing the respondent) confessed error, and for the first time the United States directly urged the Court to overrule Plessy. "Segregation of Negroes, as prac-

79. See Philip Elman, The Solicitor General's Office, Justice Frankfurter, and Civil Rights Litigation, 1946-1960: An Oral History, 100 HARV. L. REV. 817 (1987) (reporting that the Solicitor General's Office informally cooperated with NAACP and with Justice Frankfurter within the Court during this period).

80. In addition to the United States, other supportive amici included the ACLU, the AFL, the CIO, the American Jewish Committee, and the National Bar Association. Shelley, 334 U.S. at 3-4. Three amici supported the restrictive covenants. Id. at 4.

81. See Oyama v. California, 332 U.S. 633 (1948) (invalidating law barring Japanese aliens from holding land through their minor children who were American citizens); Takahashi v. Fish \& Game Comm'n, 334 U.S. 410 (1948) (striking down law barring the issuance of fishing licenses to aliens ineligible for citizenship (a category limited to Asians)); see also Section II.C.1 (discussing Oyama). In both cases, Justice Murphy wrote pointed concurring opinions linking the challenged statutes to western prejudice against Japanese immigrants. Oyama, 332 U.S. at 650; Takahashi, 334 U.S. at 422-27.

82. Justices Murphy and Rutledge favored sharp anti-racism rhetoric and swift doctrinal action; Chief Justice Vinson and Justices Frankfurter, Reed, and Jackson favored a slow but sure approach; Justices Black, Douglas, and Burton were between these warring groups. See Hutchinson, supra note 75, at 8-13.

83. Brief for Petitioner at 44-52, McLaurin v. Oklahoma State Regents, 339 U.S. 637 (1950) (1949 Term, No. 34) (urging the Court to overrule Plessy); id. at 36 (differentiating public transportation in Plessy from public education in McLaurin); Brief for Appellant at 5, Sweat v. Painter, 339 U.S. 629 (1950) (1949 Term, No. 44) (similar); see also Brief for Amici Curiae [Committee of Law Teachers Against Segregation in Legal Education] in Support of Petition for Certiorari at 4, Sweat (1949 Term, No. 44) (arguing that Plessy is flatly inconsistent with the Equal Protection Clause and should be overruled). There was significant support within the Court for the NAACP's point. See Hutchinson, supra note 75, at 15-17, 19-21.

84. Memorandum of Amicus Curiae United States at 14, McLaurin (1949 Term, No. 34); Memorandum of Amicus Curiae United States at 4-5, Sweat (1949 Term, No. 44).

85. 339 U.S. 816 (1950).

86. Brief for the United States at 40, Henderson v. United States, 339 U.S. 816 (1950) (1949 Term, No. 25) ("[T]he legal and factual assumptions" of Plessy "have been under- 
ticed in this country, is universally understood as imposing on them a badge of inferiority.... Forbidding this group of American citizens 'to associate with other citizens in the ordinary course of daily living creates inequality by imposing a caste status on the minority group.' "\$87 The government's argument in Henderson stirred up discussion within the Court as to how broadly to decide the graduate school cases. According to Dennis Hutchinson's careful reconstruction, the Justices were almost unanimous in their determination to overrule segregation in all three cases but were fearful that a broad rationale might trigger a firestorm of protest in the South ${ }^{88}$ Under these circumstances, the Court found equal protection violations in the graduate school cases, based upon intangible differences marking the black graduate school as insufficient.$^{89}$ In Henderson, the Court did not reach the constitutional issue and simply ruled that the Interstate Commerce Act barred racial discrimination in railroad dining cars..$^{90}$ Although Plessy had survived, its days were numbered - a prospect that filled the Justices with anxiety.

Marshall and the Inc. Fund persuaded the Court to take five public school cases in 1952 that, they hoped, would repudiate Plessy. Brown v. Board of Education and its associated cases were both the Austerlitz and the Waterloo of the NAACP's strategy of deploying constitutional law to advance the status and condition of black people. ${ }^{91}$ On the one hand, the school segregation cases represented the apotheosis of blacks' politics of recognition. Supported by the Solicitor General, the ACLU, and four other hefty amici, the NAACP carefully developed the constitutional case for full and unequivocal equality.

The Inc. Fund's briefs in the cases made three kinds of arguments for overruling Plessy, at least insofar as public education was concerned. First, they maintained that the purpose of the Fourteenth

mined and refuted" and the " 'separate but equal' doctrine should now be overruled and discarded.").

87. Id. at 27-28. Attorney General J. Howard McGrath argued the case along the same lines: "Segregation signifies and is intended to signify that a member of the colored race is not equal to a member of the white race."

88. See Hutchinson, supra note 75 , at $19-30$ (providing a detailed account of the Justices' deliberations in the 1949 Term Cases).

89. Sweatt v. Painter, 339 U.S. 629 (1950); McLaurin v. Oklahoma State Regents, 339 U.S. 637 (1950).

90. 339 U.S. at 826 .

91. On the Austerlitz (triumphal) part, see KLUGER, supra note 17; TUSHNET, supra note 60 (less triumphalist). On the Waterloo part, see JACQUELINE IRVINE, BLACK STUDENTS AND SCHOOL FAILURE: POLICIES, PRACTICES, AND PRESCRIPTIONS (1990); Gerald Rosenberg, The Hollow Hope: CAN COURTS Bring ABOUT SOCIAL CHANGE? (1991) (no); Sonia Jarvis, Brown and the Afrocentric Curriculum, 101 YALE L.J. 1285 (1992). For something of both, see DERRICK BELL, JR., RACE, RACISM, AND AMERICAN LAW (3d ed. 1992). 
Amendment was "to eliminate race distinctions from American law," specifically including race-based segregation of public schools. ${ }^{92}$ The early cases had enforced this understanding, but later cases like Plessy confused the Equal Protection Clause's reasonable distinction approach, applicable to the general run of statutes, with its intended "prohibition of color differentiation." argued that the more recent cases had returned to the Fourteenth Amendment's original goal and its intended bar to race-based classifications. Justice Holmes' opinion in Herndon had it right when he found it "too clear for extended argument that color cannot be made the basis of a statutory classification affecting the right set up in this case." 94 The brief carefully laid out for the Court the steps it had already taken to limit and trim back Plessy and argued that it was only a short step to overruling the precedent altogether. ${ }^{95}$

Third, and most important for my purposes, the Inc. Fund briefs emphasized normative arguments for the moral, social, and political evils of apartheid. This was most explicit in the appendix to its opening brief, "The Effects of Segregation and the Consequences of Desegregation: A Social Science Statement." 96 The central point of the statement was the pervasive and harmful psychological effects of lawendorsed segregation on its objects, namely, people of color, especially schoolchildren. Such laws signal their inferiority because of race and

92. See Brief for Appellants at 79-120, Brown v. Bd. of Educ., 347 U.S. 483 (1954) (1953 Term, Nos. 1, 2, 4, 5, 10) (general purpose); $i d$. at 120-89 (specific intent of Congress and ratifying states to bar racially segregated schools). These materials were developed in response to the Court's order for reargument of the cases.

93. Id. at $45-46$.

94. Id. at 46 (quoting Nixon v. Herndon, 273 U.S. 536, 541 (1927)). It is odd that the NAACP did not emphasize dicta in the Japanese war cases, where the Court said that racebased classifications of all sorts were presumptively unconstitutional. See supra note 67 and accompanying text. That the Court in both cases upheld race-based directives in time of war perhaps made these authorities particularly unsavory for the NAACP, which had not participated in them. In any event, other briefs in the case did rely on those earlier precedents to argue that race-based discrimination is all but prohibited by the Equal Protection Clause. See Brief of Amici Curiae American Veterans Comm. at 4-5, 12-13, Brown (1953 Term, No. $8)$.

95. Brief for Appellants at 47-50, Brown (1953 Term, Nos. 1, 2, 4, 5, 10). The Inc. Fund argued that Buchanan refused to extend Plessy to property and housing segregation, a refusal dramatically extended in Shelley. Even in the arena of transportation, subsequent cases - McCabe, Henderson - trimmed back Plessy's ambit, and Morgan v. Virginia overruled its application to interstate transportation. In the education arena, the Court had never thoroughly considered the application of Plessy, and the intangible benefits rationale of the graduate school cases - Gaines, Sipuel, Sweatt, McLaurin - provided a sound reason to reject Plessy in elementary and secondary schools as well.

96. The Statement was appended to the first set of Appellants' Briefs, Brown (1953 Term, Nos. 8, 101, 191) [hereinafter Social Science Statement]. It was signed by thirty-two eminent scientists, including Gordon Allport, Kenneth and Mamie Clark, Robert Merton, and Samuel Stouffer. 
undermine their ability to see "their own dignity as human beings." Racial segregation also contributes to rigid and authoritarian personalities among white schoolchildren and gives them a "distorted sense of social reality," perpetuates absurd stereotypes and "leads to a blockage in the communications and interaction between the two groups," of the statement supported the NAACP's longstanding position that segregation denied black people the respect they deserved as human beings and the full rights of citizenship guaranteed by the Fourteenth Amendment. In this stance, the Inc. Fund was powerfully backed up by the amicus brief for the United States, which asserted that apartheid was profoundly undemocratic. ${ }^{100}$ The latter half of the NAACP's supplemental statement maintained that racial variation is benign from a scientific point of view. ${ }^{101}$ From a policy perspective, not only does segregation contribute to psychological and social turmoil, but " $[u]$ nder certain circumstances desegregation not only proceeds without major difficulties, but has been observed to lead to the emergence of more favorable attitudes and friendlier relations between races." 102

Most of the Justices accepted the NAACP's normative arguments, but several were uncertain that they were decisive as to the constitutional issues, and all were fearful of the political turmoil they believed would follow any decision requiring desegregation of public schools. ${ }^{103}$ After reargument, and much soul-searching, a surprisingly unanimous Court in Brown v. Board of Education ("Brown I") ${ }^{104}$ accepted the Inc. Fund's invitation to declare that race-based segregation in public schools violated the Equal Protection Clause. In Bolling v. Sharpe ${ }^{105}$ the Court reached the same result for schools in the District of Columbia, under the Due Process Clause of the Fifth Amendment. Chief Justice Warren's Brown opinion invoked the importance of edu-

97. Ia. at 4 .

98. Id. at 6-7.

99. Id. at 8 .

100. Brief of Amicus Curiae United States at 2-8, Brown (1952 Term, Nos. 8, 101, 191, $412,448)$.

101. Social Science Statement, supra note 96 , at 12.

102. Id. at 15 .

103. The Court's internal deliberations, including several conferences, two rearguments, and the deft work of Chief Justice Warren (who joined the Court between the first argument (1952 Term) and the second (1953 Term)), are comprehensively set forth in KLUGER, supra note 17, at 543-747; Hutchinson, supra note 75, at 34-44; Mark Tushnet \& Katya Lezin, What Really Happened in Brown v. Board of Education, 91 CoLuM. L. REV. 1867 (1991).

104. 347 U.S. 483 (1954); see infra Sections II.C.1 and III.A. (discussing Brown I).

105. 347 U.S. 497 (1954). 
cation to citizenship, the demonstrated harms that segregated education visited on minority schoolchildren, and the intangible as well as tangible ways that a segregated school system could not deliver equal education. ${ }^{106}$ The opinion did not exactly overrule Plessy and only disavowed its reasoning to the extent inconsistent with its own rationale. ${ }^{107}$ Nonetheless, lower courts immediately agreed with the NAACP that Brown's disapproval of racial segregation extended beyond education. In a series of per curiam opinions, the Supreme Court silently affirmed those decisions. ${ }^{108}$ Brown $I$ was a great victory for the NAACP.

One year later, the Court decided Brown v. Board of Education ("Brown II"), ${ }^{109}$ where the Court announced its remedy for the violations found in Brown $I$. This was not a victory for the NAACP. The Inc. Fund argued for "immediate" relief once the Court invalidated apartheid and for decrees requiring desegregation "as quickly as prerequisite administrative and mechanical procedures can be completed." $" 10$ The Eisenhower Administration argued for remands to the various local courts where the cases originated, "with directions to carry out this Court's decision as rapidly as the particular circumstances permit[.]"111 Most of the states of the South submitted amicus briefs to the Court arguing for "a gradual adjustment" away from segregated schools, so as to accommodate the needs of school administrators and of those people unwilling to send their children to integrated public schools. ${ }^{112}$ The Supreme Court took the middle road, following the Eisenhower Administration and not the NAACP. Brown II remanded the cases to their originating courts to fashion injunctive relief

106. Brown I, 347 U.S. at 493-94.

107. Id. at 495 .

108. See New Orleans City Park Improvement Ass'n v. Detiege, 358 U.S. 54 (1958) (per curiam) (invalidating segregation in municipal parks and golf course); Gayle v. Browder, 352 U.S. 903 (1956) (per curiam) (city buses); Mayor \& City Council of Baltimore City v. Dawson, 350 U.S. 877 (1955) (per curiam) (public bathhouses and beaches); Holmes v. Atlanta, 350 U.S. 879 (1955) (per curiam) (municipal golf course).

109. Brown v. Board of Educ., 349 U.S. 294 (1955).

110. Brief for Appellants in Nos. 1, 2, and 3 and for Respondents in No. 5 on Further Reargument at 10-24, Brown v. Board of Educ., 349 U.S. 294 (1955) (1954 Term, No. 1).

111. Brief for the United States on the Further Argument of the Questions of Relief at 27-29, Brown II (1954 Term, No. 1).

112. See, e.g., Brief of Amicus Curiae John Ben Shepperd Attorney General of Texas at 3-4, Brown (1954 Term, Nos. 1, 2, 3, 4); Brief of Amicus Curiae Harry McMullan Attorney General of North Carolina at 13-18, Brown II (1954 Term, Nos. 1, 2, 3, 4); Brief of Amicus Curiae Attorney General of Florida Richard W. Ervin at 3-56, Brown II (1954 Term, Nos. 1, $2,3,5$ ) (justifying the "gradual adjustment" criterion by reference to an empirical survey by the state); Brief of Amicus Curiae Attorney General of Arkansas Tom Gentry at 13-21, Brown II (1954 Term, Nos. 1, 2, 3, 5), (arguing that the remedy in the case should be left to Congress, legislating pursuant to its authority under $\$ 5$ of the Fourteenth Amendment). 
through "such orders and decrees ... as are necessary and proper to admit to public schools on a racially nondiscriminatory basis and with all deliberate speed the parties to these cases." 113 What I am calling a politics of remediation got off to an exceedingly slow start with Brown II. As discussed below, the NAACP's petition that the Equal Protection Clause required an integrated restructuring of American public education had a very uneven reception by judges in the half century since Brown.

At the same time the NAACP was closing in on its ambiguous victory in Brown, other grass-roots groups of African Americans were pursuing other kinds of campaigns against apartheid. The most famous were boycotts and sit-ins seeking to pressure private as well as public institutions to desegregate. The Montgomery bus boycott of 1955-56 was a grass-roots movement of black citizens who organized themselves to overturn racially segregated bus service. The boycott campaign not only revealed the power of grass-roots organizing (a fact well-appreciated by the NAACP as key features of its equal pay/facilities and desegregation litigations), but brought regional and then national publicity to the struggle of African Americans and to their leaders, Dr. Martin Luther King, Jr. and the new Southern Christian Leadership Conference ("SCLC"). ${ }^{114}$ The civil rights movement became a truly mass social movement. Although the SCLC and NAACP enjoyed a rivalrous relationship, they were both dedicated to a politics of recognition similar to that articulated in the NAACP's constitutional briefs. The Inc. Fund's victory in Brown I not only gave people of color tangible hope and inspiration that their normative vision was both right and achievable, but also gave them valuable white allies in their specific activities. ${ }^{115}$ For example, the boycotters in Montgomery were able to snatch victory from the jaws of defeat when the Supreme Court affirmed a lower court order declaring segregated municipal bus service unconstitutional under Brown $I_{.}{ }^{116}$

Triumph in Brown I and Montgomery not only fueled a mass social movement of African Americans and their allies, but also triggered a politically intense "states rights" countermovement of whites

113. Brown II, 349 U.S. at 301.

114. See generally TAYlor BRANCH, PARTING THE WATERS: AMERICA IN THE KING YEARS 1954-63 (1988); GARROW, BEARING THE CROSS, supra note 17; ALDON D. MORRIS, THE ORIGINS OF THE CIVIL RIGHTS MOVEMENT: BLACK COMMUNITIES ORGANIZING FOR CHANGE (1984).

115. See David J. Garrow, Hopelessly Hollow History: Revisionist Devaluing of Brown v. Board of Education, 80 VA. L. REV. 151, 152-57 (1994) (responding to Michael J. Klarman, Brown, Racial Change, and the Civil Rights Movement, 80 VA. L. REV. 7 (1994), and ROSENBERG, supra note 91). at 63 .

116. See Gayle v. Browder, 352 U.S. 903 (1956) (per curiam); MORRIS, supra note 114, 
opposed to racial integration. ${ }^{117}$ The negative political reaction anticipated by the NAACP and the Supreme Court slowly but inexorably grew into a regional revolt. Southern whites not only denounced Brown I with increasing fervor, but many of them openly argued for nullifying it, and not a few resorted to violence. ${ }^{118}$ The result was a series of confrontations between black people's politics of recognition and southern white people's politics of preservation. The confrontations took the form of official defiance or refusal to desegregate public schools, state laws barring or harassing the NAACP and other groups, and (in the early 1960s) mass arrests of peaceful black protesters by sometimes violent white police. ${ }^{119}$

The most apparent manifestation of southern resistance was the almost complete refusal of southern school districts to desegregate in compliance with Brown I and Brown II. Most of this resistance was passive, whereby school districts ignored Brown II or made minimal gestures toward token compliance, but much resistance was open and aggressive. ${ }^{120}$ For a famous example of the latter, the governor and legislature of Arkansas directed the Little Rock school district to defy Brown, but the federal appeals court rejected this as a basis for delaying desegregation. In Cooper $v$. Aaron, ${ }^{121}$ the Supreme Court not only held the district to the terms of the lawful court decree, as the NAACP and Solicitor General urged, but went beyond the briefs to say that state officials had an obligation to obey the Constitution as it was construed by the Court. ${ }^{122}$ The Eisenhower Administration reluctantly supported the Court in Little Rock, and Congress in 1957 gave the Court further support by authorizing, in the first civil rights legislation since 1875 , the Department of Justice to initiate litigation to support voting and other civil rights against recalcitrant localities. In Griffin v. County School Board, ${ }^{123}$ the Court held that Prince Edward

117. See generally Numan V. BARTLEY, THE RISE of MASSIVE RESISTANCE (1969); Benjamin Muse, Virginia's Massive ResistanCE (1961); Francis M. Wilhoit, The POLITICS OF MASSIVE RESISTANCE (1973).

118. NeIl R. MCMILlen, The Citizens' Council: ORganized Resistance to the SECOND RECONSTRUCTION, 1954-64 (1971).

119. For detailed accounts of these and other means of segregationist resistance, see BARTLEY, supra note 117; ROSENBERG, supra note 91, at 107-56.

120. J. HARVIE Wilkinson III, From BROWN to BAKKE: THE Supreme CourT AND SCHOOL INTEGRATION, 1954-1978, at 79-102 (1979); $c f$. Mary Dudziak, The Limits of Good Faith: Desegregation in Topeka, Kansas: 1950-1956, 5 LAW \& HIST. REV. 351 (1987) (noting that there was little integration even in Topeka).

121. 358 U.S. 1 (1958) (signed by all nine Justices); see also Daniel A. Farber, The Supreme Court and the Rule of Law: Cooper v. Aaron Revisited, 1982 U. ILL. L. REV. 387; Section II.E.1 (discussing Cooper).

122. Cooper, 358 U.S. at 18-19.

123. 377 U.S. 218 (1964). 
County could not close down its public schools in an effort to evade Brown's mandate.

Southern states also lashed out at the persons and groups supporting civil rights for people of color. A number of states adopted laws aimed at the NAACP. ${ }^{124}$ For example, Alabama adopted a law requiring the NAACP to register and reveal its membership lists, and then prosecuted and fined the Association for failing to comply. The NAACP challenged the state action as inconsistent with the "free speech and free association" rights guaranteed by the First Amendment. ${ }^{125}$ This freedom, the NAACP maintained, was essential to the peaceful political "[s]olution of the American race problem." The Supreme Court unanimously agreed in $N A A C P$ v. Alabama, ${ }^{127}$ holding that the state could not interfere with the NAACP's politics of recognition. Crippled by local penalties, the NAACP was able to survive in the South only because of these constitutional protections. ${ }^{128}$

Starting in 1960 , civil rights activism took the form of peaceful sitins at segregated lunch counters and protest marches objecting to apartheid. Although the protesters were uniformly peaceful, they were often arrested for violating ordinances prohibiting breaches of the peace, disorderly conduct, obstruction of sidewalks, or parading without licenses. One after another, convictions of civil rights protesters rolled through southern state courts - only to be reversed by the U.S. Supreme Court. ${ }^{129}$ The constitutional policy animating the reversals was that local authorities were treating civil rights dissenters differently than they would have treated any other group. Doctrinally, the reversals depended upon the facts of the different cases. Some went off on the due process ground that there was not sufficient evidence to

124. See Walter Murphy, The South Counterattacks: The Anti-NAACP Laws, 12 W. POL. Q. 371 (1959).

125. See Brief for Petitioner at 21-25, NAACP v. Alabama, 357 U.S. 449 (1958) (1957 Term, No. 91).

126. Id. at 21 .

127. 357 U.S. 449 (1958).

128. The NAACP successfully relied on the Alabama precedent to challenge other indirect harassments in Bates v. Little Rock, 361 U.S. 516 (1960), NAACP v. Button, 371 U.S. 415 (1963), and Gibson v. Florida Legislative Investigation Committee, 372 U.S. 539 (1963). See also Section II.F.1 (discussing these precedents).

129. See William J. Brennan Papers, Library of Congress, Container I: 77 , Folder 6 [hereinafter Brennan Papers]. About two dozen appeals or petitions for certiorari by sit-in defendants, convicted by courts in seven southern states, came to the Court during the 1962 Term. In a series of memoranda to the Conference, the Chief Justice summarized each of the cases and presented a preliminary constitutional analysis. The Court reversed six convictions in opinions issued on May 23, 1963, and the remainder were subsequently reversed, for the most part summarily. 
meet the statutory criteria for punishment, ${ }^{130}$ others on the equal protection ground that protesters were discriminated against because of their race, ${ }^{131}$ and a good many on the First Amendment ground that the state was unreasonably regulating expressive activity. ${ }^{132}$

Even without constitutional protections, the protests and marches of the early 1960s would have transformed America, for the international news coverage displayed images of idealistic black bodies pommeled by bigoted white clubs and firehoses. ${ }^{133}$ Dr. King's pivotal Birmingham campaign energized the civil rights movement. ${ }^{134}$ Within ten weeks of the city's capitulation to the SCLC's demands in May 1963 , as many as 758 demonstrations occurred in 186 cities throughout the South. ${ }^{135}$ Within six months, the movement had triumphed in its bold March on Washington, where Dr. King's "I Have a Dream" speech (a classic articulation of the politics of recognition) inspired a generation. ${ }^{136}$ Less than a year after the march, President Johnson signed the Civil Rights Act of 1964 , which provided federal enforcement mechanisms, including the withholding of funds from discriminatory programs, as a means for finally making actual progress against public segregation and further established rules against discrimination by private employers and accommodations as well. ${ }^{137} \mathrm{~A}$ year after that, Johnson signed the Voting Rights Act of 1965, which gave teeth to the NAACP's arguments in Guinn and Allwright by establishing strong

130. E.g., Garner v. Louisiana, 368 U.S. 157 (1961) (relying on the principle of Thompson v. City of Louisville, 362 U.S. 199 (1960)).

131. E.g., Peterson v. City of Greenville, 373 U.S. 244 (1963); see also Section II.E.3 (discussing Peterson).

132. E.g., Shuttlesworth v. Birmingham, 394 U.S. 147 (1969); Cox v. Louisiana, 379 U.S. 559 (1965); Edwards v. South Carolina, 372 U.S. 229 (1963). But see Walker v. City of Birmingham, 388 U.S. 307 (1969) (upholding conviction of protesters for violating state court injunction, even though based upon ordinance invalidated in Shuttlesworth). See also Section II.F.1 (discussing Shuttlesworth, Cox, and Edwards).

133. See Michael J. Klarman, Civil Rights Law: Who Made It and How Much Did It Matter?, 83 GEO. L.J. 433 (1994) (arguing that Brown I contributed indirectly to public rejection of apartheid, by galvanizing a series of confrontations between heroic blacks and idiotic whites which provoked international shock) [hereinafter Klarman, Civil Rights Law].

134. See GlenN ESKEw, BUt fOR BIRMinghaM: THE LOCAL and NATIONAL MOVEMENTS IN THE CIVIL RightS STRUGGLE (1997).

135. Thomas R. BRooks, Walls COME Tumbling Down: A History of THE CiviL RIGHTS MOVEMENT 1940-1970 at 210 (1974).

136. See TAylor Branch, Pillar of Fire: America In THE King Years, 1963-65 (1998); GARROW, BEARING THE CROSS, supra note 17, at 277-86.

137. 42 U.S.C. $\$ 2000 \mathrm{a}-\mathrm{h}(2000)$. On the background of the CRA and the critical importance of civil rights activism, see HUGH Davis GraHAM, THE CIVIL RIGHTS ERA: ORIGINS AND DEVELOPMENT OF NATIONAL POLICY, 1960-1972 (1990). 
direct as well as prophylactic protections against efforts to deny people of color their right to vote. ${ }^{138}$

The political energy released by these developments pressed the civil rights agenda in many different directions. One was the completion of the NAACP's politics of recognition: invalidation of laws barring or criminalizing different-race marriages and cohabitation. The Supreme Court had ducked the issue in the $1950 \mathrm{~s},{ }^{139}$ presumably because white hysteria about interracial sexuality would have explosively mobilized further hostility to Brown $I .^{140}$ The NAACP renewed its objections in 1964, when it challenged the Court to strike down a Florida law criminalizing different-race cohabitation. Invoking the Japanese curfew and evacuation cases as well as Brown I, the Inc. Fund maintained that the statute was per se invidious; race must henceforth be "irrelevant" to statutory policies. ${ }^{141}$ The civil rights lawyers also directly challenged the normative coherence of the state's "racial purity" justification for the policy: scientists have debunked the idea of pure races and have shown that there are no relevant differences among the races, except perhaps for some superficial physical features; racial variation is not only benign, but Florida's treatment of it as a matter of consequence is a legacy of slavery that the Reconstruction amendments were centrally aimed at eradicating. ${ }^{142} \mathrm{~A}$ unanimous Court agreed with the NAACP in McLaughlin $v$. Florida ${ }^{143}$ and at the Inc. Fund's further petition the Court declared unconstitutional laws barring different-race marriages in Loving $v$. Virginia. ${ }^{144}$ Part I of Chief Justice Warren's opinion for the unanimous

138. 42 U.S.C. $\$ 1973 a-p(2000)$. On the background of the VRA and the critical importance of civil rights activism, see DAVID J. GARROW, PROTEST AT SELMA: MARTIN LUTHER KING, JR. AND THE VOTING RIGHTS ACT OF 1965 (1978). The best compilation of primary source material appears in 1 RACE, VOTING, REDISTRICTING AND THE CONSTITUTION: SOURCES AND EXPLORATIONS ON THE FIFTEENTH AMENDMENT 73-248 (Marsha J. Tyson Darling ed., 2001).

139. Naim v. Naim, 350 U.S. 985 (mem) (1956) (declining to review the Virginia Supreme Court decision, 87 S.E.2d 749 (Va. 1955), which upheld Virginia's racist antimiscegenation law).

140. Alexander M. Bickel, The least Dangerous Branch: The Supreme COURT AT THE BAR OF POLITICS 174 (1962) [hereinafter BICKEL, LEAST DANGEROUS BRANCH]; cf. Herbert Hovenkamp, Social Science and Segregation Before Brown, 1985 DUKE L.J. 624 (arguing that hysteria about interracial sexuality was at the heart of southern devotion to racial segregation generally).

141. Brief for Appellants at 12-13, McLaughlin v. Florida, 379 U.S. 184 (1964) (1964 Term, No. 11).

142. See id. at 20-26.

143. 379 U.S. 184 (1964) (overruling Pace v. Alabama, 106 U.S. 583 (1883)); see also Anderson v. Martin, 375 U.S. 399 (1964) (striking down Louisiana law requiring that election ballots signify race of candidates).

144. 388 U.S. 1 (1967); see Brief for Appellants, Loving v. Virginia, 388 U.S. 1 (1967) (1966 Term, No. 395) (making same arguments as the Inc. Fund's brief in McLaughlin). 
Loving Court reasoned that racial classifications resting upon policies of white purity or, even worse, white supremacy were per se invalid under the Equal Protection Clause. ${ }^{145}$

A second consequence of the new political support for civil rights was that there was finally progress toward the post-Brown politics of remediation for public school segregation. After enactment of the Civil Rights Act, the nation seemed publicly committed to the norm of desegregation, and the financial and legal resources of the federal government provided critical pressure on school districts to desegregate with more speed than deliberateness. ${ }^{146}$ The new political climate emboldened the Inc. Fund to argue more insistently for transitions from dual systems of black and white schools to unitary systems of fully integrated schools. Judge John Minor Wisdom of the Fifth Circuit accepted the NAACP's understanding of Brown in a series of decisions culminating in United States v. Jefferson County Board of Education. ${ }^{147}$ " [T] he only adequate redress for a previously overt system-wide policy of segregation directed against Negroes as a collective entity is a system-wide policy of integration." ${ }^{148}$ Systemic injury required a systemic remedy. Wisdom directed that a strong remedial decree be entered, setting forth in detail how the school districts were to proceed in order to make the transition to a unitary system. ${ }^{149}$

The Inc. Fund and the Johnson Administration's Solicitor General Erwin Griswold pressed Jefferson and the idea of immediate systemic remediation onto the Supreme Court in Green v. County School Board. ${ }^{150}$ After leaving district courts with virtually no guidance as to what steps Brown II required segregated school districts to take, the Court interpreted Brown II to impose an "affirmative duty to take whatever steps might be necessary to convert to a unitary system in

145. Loving, 388 U.S. at 9-12; see also Section II.C.1 (discussing Loving).

146. Frank Read, Judicial Evolution and the Law of School Integration Since Brown v. Board of Education, 39 LAW \& CONTEMP. PROBS. 7 (Winter 1975). The Act authorized the Justice Department to bring school desegregation lawsuits, which relieved the Inc. Fund of the full burden of litigating the cases. Pub. L. No. 88-352, $\S 407$ (a), codified at 42 U.S.C. $\S$ $2000 \mathrm{c}-6(\mathrm{a})$. The same law also barred federal monies from going to programs discriminating on the basis of race, under which HEW in 1965-66 promulgated tough guidelines requiring segregated school districts to improve their numbers if they wanted to receive federal funds. Id.; see also James Dunn, Title VI, the Guidelines and School Desegregation in the South, 53 VA. L. REV. 42 (1967).

147. 372 F.2d. 836 (5th Cir. 1966).

148. Id. at 869 .

149. Id. at $897-900$.

150. 391 U.S. 430 (1968) (striking down a freedom-of-choice plan). See Brief for Petitioners at 28, Green v. County School Bd., 391 U.S. 430 (1968) (1967 Term, No. 695); Memorandum of Amicus Curiae United States at 4-5, Green (1967 Term, No. 695). 
which racial discrimination would be eliminated root and branch."151 The duty of root and branch reform would, the Court suggested, be measured by results: if most black students were left in segregated schools by a plan, that was probably not a unitary system.

A third feature of the invigorated civil rights agenda was a more ambitious version of the old politics of protection that included some lessons from the newer politics of remediation. The NAACP and a growing array of allied groups continued to challenge state efforts to deprive people of color of their liberties, especially their electoral and criminal procedural rights. ${ }^{152} \mathrm{But}$ the Association and its allies (like the ACLU) now conceptualized their objections more broadly and posed structural solutions to repeated rights violations. Thus, various civil rights groups pressed for elimination of poll taxes and other facially race-neutral means of black disenfranchisement. ${ }^{153}$ They worked with the Department of Justice to craft the Voting Rights Act, which not only protected against discrimination, but also established tough prophylactic measures to assure federal monitoring of southern voting practices and rules. Lawsuits challenged a whole array of structures that assertedly undermined equal service of blacks on juries, and in 1964 the NAACP persuaded the Supreme Court to allow weak judicial monitoring of prosecutors' use of peremptory challenges that excluded blacks from juries. ${ }^{154}$ In 1963 , the NAACP initiated a campaign against the death penalty, which had long been applied in a racially discriminatory manner. (Section II.D discusses this campaign in some detail.)

\section{The Politics of Remediation and the New Politics of Preservation, 1972-Present}

Before World War II, most white opposition to desegregation or racial equality was driven by open commitments to a natural law philosophy in which racial differences were viewed as profound and ma-

151. Green, 391 U.S. at $437-38$. This was a burden on the school board "to come forward with a plan that promises realistically to work, and promises realistically to work now." Id. at 439.

152. See, e.g., United States v. Mississippi, 380 U.S. 128 (1965) (striking down literacy tests applied in a racially discriminatory manner); Gomillion v. Lightfoot, 364 U.S. 339 (1960) (invalidating a gerrymander designed to minimize black voting); see infra Section II.E.1 (discussing Gomillion).

153. See U.S. ConST, amend. XXIV, $\& 1$ (barring poll taxes); Carter v. Jury Comm'n, 396 U.S. 320 (1970) (challenging a structure for jury selection that yielded discriminatory patterns).

154. See Swain v. Alabama, 380 U.S. 202 (1965). 
lignant and the white race's purity was threatened by racial mixing. ${ }^{155}$ Such natural law attitudes were the primary engine for southern white "massive resistance" to Brown $I$ and any form of racial integration in the 1950 s. ${ }^{156}$ As the civil rights movement gained political support outside the South, a more moderate oppositionist stance developed: denying that they viewed racial differences as malignant and sometimes conceding that change must come to the South, moderates opposed legal or constitutional requirements on pragmatic grounds - they were not needed, they would not work, they would be counterproductive, and so forth. ${ }^{157}$ Whereas natural law conservatives sought to preserve as much of an enclave for racial segregation as they could, pragmatic conservatives did not publicly claim segregation as a goal, but instead argued against remedial responses that were "excessive" from the community's perspective.

Although driven by different substantive commitments and presentation, both natural law and pragmatic preservationists invoked the Constitution. For them, desegregation imposed by judges in Washington, D.C. was at war with (1) the federalist structure, where states were entitled to set local policy, without interference from the national government; (2) the constitutional separation of powers, whereby the popularly elected legislature is both the most legitimate and the most institutionally competent state organ to handle complex, polycentric issues of educational policy; and (3) the liberties of white people, such as their right not to associate with black people (and vice versa) and their right not to be subject to "reverse discrimination." 158

However expressed, the politics of preservation was a losing reactionary cause in the 1950 s and early 1960 s, when its "massive resistance" was dominated by natural law extremists who stubbornly insisted on formal apartheid. Once the civil rights agenda shifted in the

155. See Hovenkamp, supra note 140 , at $627-37$. This kind of thinking remained popular in the South after the war, See, e.g., DAN T. CARTER, THE POLITICS OF RAGE: GEORGE WALlace, THE ORIGINS OF THE NEW CONSERVATISM, AND THE TRANSFORMATION OF AMERICAN POLITICS (1995) [hereinafter CARTER, POlitics OF RAGE].

156. See BARTLEY, supra note 117 , at 237-39, 320-22, 326-32 (providing detailed reporting of stated opposition to integration grounded in natural law); MCMILLEN, supra note 118 , at 161-88 (giving a complicated description of the "scientific," religious, historical, and sociological strands of local oppositionists' natural law attitudes).

157. See BARTLEY, supra note 117, at 338-39 (documenting the decline of massive resistance and ascendance of pragmatic opposition); ROBERT A. CARO, THE YEARS OF LYNDON JOHNSON: MASTER OF THE SENATE 182-201 (2002) (contrasting old-style segregationists like Theodore Bilbo with pragmatic segregationist Richard Russell, but icily demonstrating that Russell was privately just as racist as Bilbo).

158. For examples of these constitutionalized arguments against integration "forced" by federal judges upon unwilling states, see CARTER, POLITICS OF RAGE, supra note 155, at 136-38, 157-58 (Governor George Wallace); WILKINSON, supra note 120, at 80-84 (southern state court judges, mainly hysterical opponents). 
late 1960 s, from the virtually completed recognition phase (Loving $v$. Virginia) to a serious process of remediation, the politics of preservation shifted its focus to pragmatic arguments and gained support from moderates and nonracists. Once people of color could no longer claim that the state was openly disrespecting their equal citizenship, moderate whites were less impressed with the urgency of their claims. And when their constitutional demands shifted from formal equality to actual equality, preservationists could emphasize practical rather than dignitary arguments. The white audience was particularly receptive to pragmatic claims that black people's remedial demands would impose significant costs on the white community - not just the monetary costs of implementation, but more fundamentally (and speculatively) degradation in public schooling, reallocation of economic entitlements, and intrusions of federal bureaucrats and judges into local matters. ${ }^{159}$ Elected President in 1968, Richard Nixon appealed to the new centrist politics of preservation: his campaign reaffirmed the antiapartheid norm but aligned Nixon with southern and blue-collar whites by endorsing localism and equality of opportunity, shibboleths for the new opposition to civil rights. ${ }^{160}$ Nixon's four Supreme Court appointments (1969-71) echoed his civil rights pragmatism. Always reasserting formal equality for Americans of all races and ethnicities, the Burger Court between 1970 and 1978 set forth limits to the Warren Court's potentially expansive constitutional protections for people of color. ${ }^{161}$ A moderate politics of preservation won an even bigger victory when Ronald Reagan was elected president in 1980. Prodded by post-civil rights federalists, the Reagan Court has more vigorously protected the racial status quo against civil rights perturbation, under the same doctrinal flags (localism, institutional competence, and white people's rights), but more aggressively waved.

The dialectic between a civil rights politics of remediation and

159. See generally Jonathan Rieder, The Rise of the Silent Majority, in THE RISE AND FALL OF THE NEW DEAL ORDER, 1930-1980, at 243-66 (Steve Fraser \& Gary Gerstle eds., 1989). On the changing white opposition to the civil rights movement after the 1950s, see HOWARD SCHUMAN ET AL., RACIAL ATTITUDES IN AMERICA: TRENDS AND INTERPRETATIONS 99-170 (1997); ROBERT C. SMITH, RACISM IN THE POST-CIVIL RIGHTS ERA: Now You SEe IT, Now You DON'T (1995); DAVID T. WEllMaN, PORTRAITS OF WHITE RACISM 27-62, 223-47 (1993).

160. See CARTER, POLITICS OF RAGE, supra note 155 , at 326-31, 349-51, 386-99; DEAN J. KoTlOWSKI, NiXON'S CIVIL RIGHTS (2001); STEVEN F. LAWSON, IN PURSUIT OF POWER: SOUTHERN BLACKS AND ELECTORAL POLITICS, 1965-1982 at 121-57 (1985) (describing Nixon's "southern strategy" in 1968).

161. The relationship of the Burger Court to the Warren Court is complicated. The Burger Court expanded many Warren Court initiatives (criminal procedure, see Section II.A.1; the death penalty, see Section II.D), but on matters touching racial justice the Burger Court typically drew the line at issues settled by the Warren Court and refused to proceed further (see this Section, Section II.C, and Section II.E). 
preservationist objections played out most dramatically in the Brown II cases. As public schools were actually integrated, often through federal busing orders, white communities often accepted pragmatic arguments that the civil rights remedy was undermining public education and that their own children were being harmed. Because moderates were unwilling to retreat from Brown I, the open battleground was what Brown II and Green required. Similar debates resulted from the civil rights movement's demands that the state revisit allocational policies that were racially neutral on their face but had racially discriminatory effects and that governments engage in affirmative action to integrate state workforces and public works projects. Although the doctrinal playing out of the constitutional arguments differed, the school desegregation, discriminatory effects, and affirmative action cases all illustrated the normative debate between the civil rights vision of an actually integrated America and the preservationist vision of a formally colorblind America.

a. Busing and the School Desegregation Decrees. As suggested above, the NAACP's politics of remediation insisted on more than formal desegregation of public schools, and the Supreme Court seemed to accept that vision in Green. After Green, district judges developed detailed decrees for actual school integration, usually in consultation with education experts and the school districts. For rural districts such as the one in Green, remediation was fairly straightforward, as there were few schools and students could be shifted around without much physical difficulty. Larger urban districts presented harder remedial trade-offs, for segregated housing patterns meant that more ambitious changes would have to occur - and the plans yielding the most integration were those requiring busing of students away from their neighborhood schools. The most famous effort was that of Judge James McMillan, whose decree reconfigured the CharlotteMecklenburg (North Carolina) school system, pervasively reassigned teachers and students with an eye toward achieving racial balance, and required that thousands of students be bused to school every day. The Fourth Circuit reversed this ambitious decree as overenforcing Brown II. The Supreme Court reinstated Judge McMillan's decree in Swann v. Charlotte-Mecklenburg Board of Education. ${ }^{162}$

The briefs in the case reflected the shift in preservationist constitutionalism toward pragmatic arguments for going slowly, and away from abrasive claims of absolute entitlement. In Green, the state had argued that integration such as that pressed by the Inc. Fund was at war with the "fundamental right of parents to direct the education of

162. 402 U.S. 1 (1971). For a detailed account of the Justices' deliberation, see BERnaRd SCHWARTZ, SWANN'S WaY: THE SCHOOL BUSING CaSE AND THE SuPREME COURT (1986) [hereinafter SCHWARTZ, SWANN'S WAY]. 
their children" and with the deference courts should show to local educators. ${ }^{163}$ The briefs in Swann hardly neglected these themes, but the most sophisticated brief, authored by Richmond attorney Lewis Powell, emphasized pragmatic reasons why Judge McMillan should not have required massive busing. On the one hand, Powell emphasized the enormous costs of busing - the psychic harms to children removed from familiar environments and the loss of the huge advantages of neighborhood schools. ${ }^{164}$ On the other hand, he argued that the apparent advantage of busing - actual school integration - was unrealistic, because in the longer term busing would accelerate the flight of white parents and their children toward private schools or schools in areas without busing orders. ${ }^{165}$

Powell's argument appealed to Chief Justice Burger, who sought to impose federalism and cost-benefit limits on trial judges crafting Green remedial decrees. But Burger's colleagues insisted on revisions to his draft opinions that were so extensive that the final, unanimous opinion in Swann was a complete triumph for the Inc. Fund. ${ }^{166}$ Its central holding was that once a Brown I violation had been shown, the federal district court has broad equitable powers to remedy the violation. The opinion in Swann praised Judge McMillan and affirmed his decree, including his goal of achieving a 71/29 white/black balance in as many schools as possible. Although this remedy was explicitly racebased, the Court construed it as not imposing a rigid quota onto the school system and justified it as a flexible goal. ${ }^{167}$ As a warning to judges in other cases, the Court admonished that Brown violations warranted "a presumption against schools that are substantially disproportionate in their racial composition." ${ }^{168}$ Finally, the Court upheld the busing requirement, based upon the trial judge's finding that it was necessary to remedy the Brown violations and notwithstanding the

163. Brief for Respondents at 26, Green v. County School Bd., 391 U.S. 430 (1968) (1967 Term, No. 695). This brief, in turn, was much more moderate than the fervent appeal to states rights and freedom of association in Brief for the Board of Supervisors of Prince Edward County, Griffin v. County School Bd., 377 U.S. 218 (1964) (1963 Term, No. 592).

164. Brief of Amicus Curiae Commonwealth of Virginia at 22-25, Swann v. CharlotteMecklenburg Bd. of Educ., 402 U.S. 1 (1971) (1970 Term, Nos. 281, 349).

165. Id. at 16 .

166. Although Burger assigned the opinion for the Court to himself, Justices Brennan and Stewart engineered a palace coup that essentially took over the opinion-drafting process. See SCHWARTZ, SWANN'S WAY, supra note 162, at 100-84.

167. Swann, 402 U.S. at $22-25$.

168. Id. at 26. 
cost-benefit, federalism, and separation of powers objections raised by the various briefs. ${ }^{169}$

As had earlier cases, Swann came from a southern or border state, but segregated schools were a national phenomenon. Keyes v. School District No. $1^{170}$ was the first post-Brown Supreme Court desegregation case outside the South. Part of the Denver school system had been manipulated to achieve racially segregated schools in violation of Brown I, and the issue presented was whether that justified a city-wide remedy under Green. The Court was narrowly divided but inclined to follow Justice Brennan's proposal of a remand with instructions to consider city-wide busing. There was a complication. Lewis Powell, the pragmatic advocate in $S w a n n$ but a Justice in Keyes, proposed that the Court extend Green's broad remedial obligations beyond districts that had been segregated de jure to those that were segregated de facto. Powell's biographer maintains that there was a Court majority for his position, but because Powell parted company with these colleagues on the busing issue he was unwilling to join forces with Brennan to write his de facto segregation views into law. ${ }^{171}$ Because the Court never revisited the issue, the de jure/de facto distinction serendipitously became a controlling principle of law in the school desegregation cases.

In Milliken v. Bradley, ${ }^{172}$ Justice Powell's pragmatic preservationism placed an important limit on the Green-Swann remedial juggernaut. The issue was whether a finding of de jure school segregation in one school district (Detroit) justified a remedial order extending to other districts (the suburbs) if the district court found that racial integration was not possible otherwise. The state objected that this broad a remedy not only violated the due process rights of the non-culpable districts, but was at war with the principle of local control of public education. ${ }^{173}$ The Nixon Justices, joined by Stewart, rested on a legal-

169. Id. at 29-31; $c f$. id. at 17-18 (noting that Title IV precluded the Justice Department from seeking busing as a remedy for school segregation but disclaiming that as a limitation on judicial orders).

170. 413 U.S. 189 (1973).

171. According to JOHN C. JEFFRIES, JR., JUSTICE LEWIS F. POWELL, JR. 302-05 (1994) [hereinafter JEFFRIES, JUSTICE POWELL], Brennan offered to redraft his opinion to discard the de facto-de jure distinction, but not at the cost of diluting Swann's approval of busing. Because he was so opposed to busing for pragmatic reasons, Keyes, 413 U.S. at 237-52 (Powell, J., concurring in part and dissenting in part), Powell went his own way, and his attack on the distinction, $i d$. at 223-36, drew the support only of Justice Douglas in the end. Id. at 21417 (Douglas, J.).

172. 418 U.S. 717 (1974).

173. See Brief for Petitioners at 82-85, Milliken v. Bradley, 418 U.S. 717 (1974) (No. 73 434) (citing Wright v. Council of the City of Emporia, 407 U.S. 451, 469 (1972), and San Antonio Indep. Sch. Dist. v. Rodriguez, 411 U.S. 1, 49-50, 54 (1973) (Powell, J.)); see also Section II.C (discussing Rodriguez). 
ism (the remedy should match the violation) but also endorsed Powell's pragmatic concerns with busing. "No single tradition in public education is more deeply rooted than local control over the operation of schools," wrote the Chief Justice; "local autonomy has long been thought essential both to the maintenance of community concern and support for public schools and to quality of the educational process."174 Although the Supreme Court, often over the dissents of Powell and Rehnquist, sometimes approved broad remedial orders sought by the Inc. Fund and other civil rights lawyers, ${ }^{175}$ the tide turned with Milliken: for reasons of both federalism and pragmatism, local control of schools was a value that had to be considered alongside the rights of black schoolchildren. ${ }^{176}$

Milliken can be viewed as a self-fulfilling prophecy: once white parents could count on the Supreme Court to respect district lines, they could predictably avoid integration by moving across those lines. And they did, in large numbers. ${ }^{17}$ The complex interaction between private choice and public policy that generated white flight posed a dilemma for both the civil rights movement and the Supreme Court. The former pressed for ever-expanding (and expensive) remedial orders, which federal judges often issued, and which the Court sometimes affirmed, but only after soul-searching as to whether the orders struck the right balance between the goal of integration and the costs accompanying movement away from neighborhood schools. ${ }^{178}$ Experience with this process has moved public debate beyond Brennan's faith in the efficacy of remedial injunctions (Green) and Powell's nostalgia for the neighborhood school (Milliken).

In the last decades of the millennium, the Inc. Fund maintained that white flight and ongoing school (re)segregation were in part a consequence of a multitude of public policies (especially housing) that

174. Milliken, 418 U.S. at $741-42$ (citing the same cases as the state).

175. See, e.g., Hills v. Gautreaux, 425 U.S. 284 (1976).

176. See, e.g., Dayton Bd. of Educ. v. Brinkman, 433 U.S. 406, 410 (1977); Pasadena Bd. of Educ. v. Spangler, 427 U.S. 424 (1976).

177. See James Coleman et al., Trends in School Segregation, 1968-73 (1975) (laying out and supporting white flight thesis); RAYMOND WOLTERS, THE BURDEN OF BROWN: THIRTY YEARS OF DESEGREGATION (1984) (documenting the effects of white flight to resegregate the school districts involved in the Brown litigation). But see GARY ORFIELD, THE GROWTH OF SEgREgation IN AMERICAN SCHOOls: ChangING PATTERNS OF SEPARATION AND POVERTY SINCE 1968, at 6 (1994) (disputing "white flight" thesis).

178. Divided Courts upheld broad and expensive remedial orders in Missouri v. Jenkins, 495 U.S. 33 (1990), and Milliken v. Bradley, 433 U.S. 267 (1977) ("Milliken II"), but even great expenditures of money toward magnet schools and other integrative measures have generated disappointing levels of actual integration. 
influenced private choices. ${ }^{179}$ Hence, civil rights attorneys defended not only extensive remedial decrees embodying attractive and comprehensive educational reform, but also housing desegregation, as people's preferences changed in response to new government programs. ${ }^{180}$ In the same period, neo-federalists opposing further judicial remediation of a resegregated status quo denied the relevance of such a complex chain of causation or the capacity of remedial decrees to break that chain. Moreover, they questioned whether school districts in the 1990s had any continuing accountability for segregationist policies that ended in the $1960 \mathrm{~s} .{ }^{181}$ They insisted that, because primary accountability for educational policy must rest with state and local governments, district courts must tailor their remedial orders so as to protect the "local autonomy" of the school district. ${ }^{182}$ Populated by Reagan-Bush Justices, the Supreme Court has cautiously moved in the neo-federalist direction. ${ }^{183}$ As Justice Kennedy put it, "[r]eturning schools to the control of local authorities at the earliest practicable date is essential to restore their true accountability in our governmental system." ${ }^{184}$ The Rehnquist Court's message is that once local governments resume full control of school systems, they will be responsive to their obligation to preserve a unitary school system. That remains to be seen.

b. The Disparate Impact Cases. Well before Loving, the NAACP recognized that, even as apartheid was dying as a formal matter, its legacy remained strong as a functional matter. Especially in the South, many policies that did not deploy race as a classification still had strong race-based effects, either because they were devised or en-

179. See "School Segregation and Residential Segregation: A Social Science Statement," appendix to Brief for Respondents at app. 1a-28a, Columbus Bd. of Educ. v. Penick, 443 U.S. 449 (1979) (No. 78-610).

180. See "School Desegregation: A Social Science Statement," appendix to Brief of Amici Curiae NAACP et al. in Support of Respondents, Freeman v. Pitts, 503 U.S. 467 (1992) (No. 89-1290) (signed by fifty-two eminent social scientists).

181. Brief for the United States as Amicus Curiae at 28-29, Board of Educ. v. Dowell, 498 U.S. 237 (1991) (No. 89-1080) [hereinafter U.S. Amicus Brief in Dowell] (signed by Bush Administration Solicitor General Kenneth Starr); accord Brief of the DeKalb County Board of Education as Amicus Curiae in Support of Petitioner at 24-28, Bd. of Educ. v. Dowell, 498 U.S. 237 (1991) (No. 89-1080) (signed by former Reagan Administration Solicitor General Rex Lee).

182. U.S. Amicus Brief in Dowell, supra note 181, at 21-24.

183. See Freeman v. Pitts, 503 U.S. 467 (1992) (holding that the district court has Swannbased discretion to order partial withdrawal of its jurisdiction once it finds local authorities have remedied the de jure violations, even though de facto segregation may persist); Board of Educ. v. Dowell, 498 U.S. 237, 238 (1991) (holding that the principle of local control requires dissolution of a Green remedial decree "after the local authorities have operated in compliance with it for a reasonable period [of time]").

184. Freeman, 503 U.S. at 490; see id. at 506-07 (Scalia, J., concurring) (ridiculing the notion that school districts have responsibility for continuing segregation). 
forced in a race-based way or because they impacted people of color disproportionately for some other reason, such as poverty or joblessness, that could be understood as a legacy of apartheid. ${ }^{185}$ In the early 1960s, the NAACP initiated constitutional litigation against the death penalty and the poll tax because they systematically disadvantaged people of color as a class. ${ }^{186}$ These campaigns were relatively successful because they spoke to important deprivations that were historically tied to the policy of white supremacy and because remediation was not considered costly.

In the late 1960s, the Inc. Fund and other groups turned their attention to state and local policies allocating resources to government services and social welfare. Allocative policies that were formally raceneutral often operated in racially discriminatory ways, and civil rights attorneys argued that state and local governments were constitutionally obliged to revamp their policies to erase or ameliorate the racebased effects. Note the parallel with Keyes' de jure/de facto distinction. As in the school desegregation cases, preservationists and their allies were able to refocus the debate. When the state was not deploying a race-based classification, it was harder to understand its action as a violation of Brown and easier to worry about the costs of remediation. Because any remedy would explicitly redistribute resources away from white people to people of color, the former were especially open to objections. Supported by a cost-conscious Nixon Administration, state and local governments strongly resisted civil rights challenges to their allocative policies. As with school desegregation cases, state and local governments invoked principles of federalism and their own superior competence to make allocational choices.

These arguments first showed up in constitutional challenges to policies by which states apportioned welfare benefits. ${ }^{187}$ In Dandridge v. Williams, ${ }^{188}$ the Supreme Court rejected an equal protection attack on Maryland's policy of capping family grants irregardless of the size of the family. Justice Stewart's opinion for the Court found the policy indistinguishable from other social and economic regulations routinely afforded lenient judicial scrutiny but recognized that welfare laws "infected with a racially discriminatory purpose or effect" would be "in-

185. See Charles Lawrence, III, The Id, the Ego, and Equal Protection: Reckoning with Unconscious Racism, 39 STAN. L. REV. 317 (1987).

186. Brief for Appellants at 19-22, Harper v. Virginia State Bd. of Elections, 383 U.S. 663 (1966) (1965 Term, No. 48) (poll tax); Section II.D (death penalty).

187. On the welfare rights movement, see MARTHA F. DAVIS, BRUTAL NEED: LAWYERS AND THE WELFARE RIGHTS MOVEMENT, 1960-1973 (1993).

188. 397 U.S. 471 (1970). 
herently suspect" and therefore subject to heightened scrutiny. ${ }^{189}$ This dictum triggered a challenge to Texas's welfare program, which included a computation procedure which funded recipients of Aid for Families with Dependent Children ("AFDC") benefits at $75 \%$ of their recognized need, whereas recipients of other, adult-only programs were funded at $95-100 \%$ of their recognized need. Professor Ed Sparer's brief for the challengers demonstrated in painful detail that the three advantaged programs had largely white beneficiaries, while the disadvantaged program (AFDC) was $85 \%$ minority $(45 \%$ black, $40 \%$ latino). ${ }^{190}$ The state claimed that governments could not reasonably be held liable for racially disparate consequences of their policies, unless there was evidence of discriminatory motives (none in the Texas case). Sparer responded that legislative motive was irrelevant: it was hard to prove, especially after Loving exposed any kind of racebased preference to lethal review; the reason for discrimination had little bearing on its effect on racial minorities deprived of needed state benefits and confronted with legislative indifference to their plight; if legislative motive were key, then the legislature could easily fix old discriminatory policies by reenacting them under a clean record. ${ }^{191}$

The four Nixon Justices were unreceptive to Sparer's arguments; they and Justice White lined up behind Chief Justice Burger's view that "Texas' allocation among the groups is beyond our reach absent invidious discrimination," namely, a showing of discriminatory intent. ${ }^{192}$ Justice Rehnquist's opinion for the Court in Jefferson $v$. Hackney ${ }^{193}$ ruled that, notwithstanding the significantly different racial impact, Texas's allocation scheme was legitimate under the Equal Protection Clause, so long as it was "lacking in racial motivation" and was otherwise rational. Rehnquist's reasoning was institutional: any allocative state program is going to affect different racial groups differently, and so heightened scrutiny for disparate racial impacts, as Sparer was arguing, would inject the Court into "intractable economic, social, and even philosophical problems presented by public

189. Id. at 485 n.17; see also Griggs v. Duke Power Co., 401 U.S. 424 (1971) (interpreting Title VII to regulate employment policies having racially disparate impacts unless they can be justified by business necessity).

190. Brief for Appellants at 29, Jefferson v. Hackney, 406 U.S. 535 (1972) (No. 70-5064).

191. Id. at 49-51 (elaborating on the Court's holding and reasoning in Palmer v. Thompson, 403 U.S. 217 (1971) (holding legislative intent irrelevant to show city closed down swimming pools rather than integrate them)).

192. Douglas Conference Notes for Jefferson v. Hackney (Feb. 25, 1972), in William O. Douglas Papers, Library of Congress, Container 1559 (O.T. 1971, Opinions, Misc. Mems. No. 70-5064) [hereinafter Douglas Papers].

193. 406 U.S. 535,548 (1972). 
welfare assistance programs [which] are not the business of this Court.' "194

Following immediately on the heels of Hackney was a challenge to Texas's system for financing public schools, San Antonio Independent School District v. Rodriguez. ${ }^{195}$ Plaintiffs' main argument was that the neediest districts were shortchanged by the Texas system because of their poverty, but they and their amici (including the Inc. Fund and the ACLU) more broadly argued that the Texas system was subject to heightened scrutiny because it was grounded upon wealth-based classifications or had strong race-based effects; the education deficit assured by the financing inequities fell mostly on latino and black schoolchildren. ${ }^{196}$ Justice Powell's opinion for the Court (the Nixon Justices plus Stewart) ignored the racial impact argument but, tellingly, responded to the wealth argument with the admonition, citing Hackney, that the challengers had failed to show that "the financing system is designed to operate to the peculiar disadvantage of the comparatively poor." ${ }^{197}$ At the same time the Court was embracing a restrictive view of judicial review of policies having race-based effects in Rodriguez, it was accepting the importance of the de jure/de facto distinction for school segregation in Keyes. The die was cast against vigilant judicial scrutiny of public policies with disproportionate effects on people of color by the end of 1973.

Before the Inc. Fund could engineer a better test case for its view that state policies bearing disproportionately on people of color should be subjected to heightened scrutiny, the Court seized upon a statutory case to settle the issue. Washington $v$. Davis ${ }^{198}$ involved claims that the District of Columbia's reading test for police officers excluded a disproportionate number of black applicants. Plaintiffs' original complaint alleged a constitutional violation, but the lower court granted relief under Title VII, which went into effect after the complaint had been filed. On appeal to the Supreme Court, the parties treated this as a Title VII case. Even after constant (almost comical)

194. Id. at 551 (quoting Dandridge v. Williams, 397 U.S. 471, 487). Three Justices dissented from this constitutional analysis. $I d$. at 551 (Douglas, Brennan, J.J. dissenting); id. at 558 (Marshall, Brennan, J.J., dissenting).

195. 411 U.S. 1 (1973)

196. This was an ancillary point in the Brief for Appellees at 16-17, San Antonio Independent School Dist. v. Rodriguez, 411 U.S. 1 (1973) (No. 71-1332), but was the lead argument in Brief [Amici Curiae] of ACLU [et al.] at 14-23, Rodriguez (No. 71-1332), and Brief of Amicus Curiae NAACP Legal Defense Fund and Educational Fund, Inc. at 3-9, Rodriguez (No. 71-1332).

197. Rodriguez, 411 U.S. at 26 (emphasis added); see also id. at $27 \mathrm{n} .62$ (citing Jefferson v. Hackney, 406 U.S. 535 547-49 (1972), and John Hart Ely, Legislative and Administrative Motivation in Constitutional Law, 79 YALE L.J. 1205, 1258-59 (1970)).

198. 426 U.S. 229 (1976). 
prompting from the Nixon Justices to take a harder line, both federal and D.C. respondents repeatedly conceded at oral argument that Title VII applied and that its disparate impact approach was the same as the equal protection approach. ${ }^{199}$ Undeterred by lack of support from the government, the Court ruled that it would not apply heightened scrutiny to a state policy having a racially discriminatory impact unless the policy was also racially motivated. ${ }^{200}$ The reasons were the same institutional process ones given in Hackney.

Although they did not litigate any of these cases (and participated only in Rodriguez, as an amicus), the Inc. Fund and its allies found its subsequent disparate impact challenges doomed by the difficulties in proving racial motivation. Precisely as Sparer had predicted in Hackney, racial motivation has been all but impossible to prove in most cases, because everyone now knows not to make public racist statements and most government decisions are complicated enough that they can be plausibly defended along non-racial lines. Accordingly, serious challenges, backed up by impressive statistics, have failed against racially disparate public housing policies, ${ }^{201}$ sentencing for drug crimes, ${ }^{202}$ and impositions of the death penalty. ${ }^{203}$ Moreover, neo-federalists have deployed Washington $v$. Davis to support their restrictive understanding of state responsibility for continuing school segregation: once the local government has taken steps to end de jure segregation, courts should not impose further responsibility on it unless there is evidence of discriminatory intent. ${ }^{204}$

c. The Affirmative Action Cases. Even under the regime of Washington v. Davis, public as well as private institutions had incentives to integrate and to do so in a non-token manner. ${ }^{205}$ These incen-

199. See Oral Argument in Washington v, Davis, 426 U.S. 229 (1976), in 88 LANDMARK BRIEFS AND ARGUMENTS OF THE SUPREME COURT OF THE UNITED STATES: Constitutional Law 355, 362, 366-67, 380-81 (Philip B. Kurland \& Gerhard Casper eds., 1977) [hereinafter LANDMARK BRIEFS]. After Mark Evans, representing the federal respondents, made this concession, id. at 369, Justice Rehnquist tossed Jefferson $v$. Hackney in his face - and Evans still backed away from the argument that won him the case! Id. at 37071.

200. Washington v. Davis, 426 U.S. at 239-45.

201. Village of Arlington Heights v. Metro. Hous. Dev. Co., 429 U.S. 252 (1977).

202. United States v. Armstrong, 517 U.S. 456 (1996). The equal protection issue is exhaustively discussed in RANDALL KENNEDY, RACE, CRIME, AND THE LAW 357-59, 364-86 (1997) [hereinafter KENNEDY, RACE, CRIME]; David Sklansky, Cocaine, Race, and Equal Protection, 47 STAN. L. REV. 1283 (1995).

203. McCleskey v. Kemp, 481 U.S. 279 (1987); see also KENNEDY, supra note 202, at 328-50 (exhaustively discussing McCleskey); Section II.D (discussing McCleskey).

204. See U.S. Amicus Brief in Dowell, supra note 181, at 19-20, $27-29$ (submitted by Bush Administration Solicitor General Kenneth Starr).

205. (1) Many of the institutions had a history of racial discrimination and so were vulnerable to challenges under Washington v. Davis. (2) After 1972, Title VII applied to federal, state, and local employers, which risked Griggs v. Duke Power Co., 401 U.S. 424 (1971), 
tives generated a variety of policies using race as a basis for preference or even a quota for allocating jobs, college spots, and government contracts. Although there was some diversity of opinion, most civil rights leaders favored affirmative state action as a swift, and perhaps necessary, mechanism to integrate state colleges, workforces, and public programs. Were these policies constitutional? The Court in Swann had approved remedial uses of race-based classifications by trial judges crafting Green decrees. ${ }^{206}$ But the "benign" use of race in allocating scarce benefits posed more intense political and constitutional issues. ${ }^{207}$ "Affirmative action" was an object of a civil rights politics of remediation - but "reverse discrimination" became an intense focus of a new post-apartheid politics of preservation, because it was an issue that infuriated extremists who hated the idea of integration, irked pragmatists who supported integration only so long as it was costless, and disturbed liberals who believed in the "colorblind constitution." 208

The multifaceted opposition to affirmative action showed up in the first major Supreme Court case, DeFunis v. Odegaard. ${ }^{209}$ Marco DeFunis, a Sephardic Jew, was denied admission to the University of Washington School of Law, while people of color with lower test scores were admitted under an affirmative action plan. DeFunis's lawyers argued that affirmative action violated the colorblindness requirement of Loving and created "special privileges" for blacks while it denied whites "fundamental" rights. ${ }^{210}$ Writing for amicus B'nai B'rith, Professors Alexander Bickel of Yale and Philip Kurland of Chicago took a broader oppositionist view. Linking quotas for blacks with the numerus clausus that has traditionally been deployed to ex-

lawsuits if their workforces were racially imbalanced. (3) Most important, social norms had changed in many locales: diversity within the institution was increasingly considered a positive goal, not just something the institution "had" to do.

206. Swann v. Charlotte-Mecklenburg Bd. of Educ., 402 U.S. 1, 16 (1971) (holding that it is allowable for school officials to aim at a racial balance in assigning students and teachers to various schools, "in order to prepare students to live in a pluralistic society[,]" and that trial judges have "broad power to fashion a remedy that will assure a unitary school system").

207. Note that the use of race in redistricting also raises identity politics as well as constitutional issues. The Supreme Court upheld state decisions challenged on race grounds, see United Jewish Orgs. v. Carey, 430 U.S. 144 (1977), until Shaw v. Reno, 509 U.S. 630 (1993), and its progeny. See also Section II.E.1 (discussing gerrymandering cases).

208. For intense opposition from legal liberals, see Lino A. Graglia, Special Admission of the "Culturally Deprived" to Law School, 119 U. PA. L. REv. 351 (1970); John Kaplan, Equal Justice in an Unequal World: Equality for the Negro - The Problem of Special Treatment, 61 Nw. U. L. REV. 363 (1966).

209. 416 U.S. 312 (1974).

210. Petitioners' Opening Brief at 12, 14, DeFunis v. Odegaard, 416 U.S. 312 (1974) (No. 73-235) (emphasis in original). 
clude Jews, they objected that affirmative action was inconsistent with the fundamental values of a liberal society: "For a quota is not merely a racial classification. It is an attribution of status - of caste - fixed by race. A quota necessarily legislates not equality, but a governmental rule of racial differences without regard to an individual's attributes or merits."211 The state's position was that affirmative action in service of racial integration was "benign" and therefore not unconstitutional under Loving; considering race was a means to undermine racism, not support it. Civil rights amici argued that race-based preferences were not "invidious" when they were deployed for remedial purposes, to implement long-overdue integration and overcome historical racial disadvantages. ${ }^{212}$ Bickel and Kurland responded that a "quota system is admittedly not 'benign' so far as the excluded [white] majority applicants are concerned" - nor was there any basis for denying that it is " 'invidious' and 'stigmatizing' for the category of applicant labeled by race as incapable of meeting the standards applied to others." 213 Quotas would tar all people of color, as a symbolic statement that " 'black people just don't have it' " and need special government help. ${ }^{214}$ In short, race-based preferences are unconstitutional for two interrelated reasons: preferring a black person because of her race deprives the white person of his right to be treated fairly and promotes rather than undermines racist stereotypes and prejudices.

Reflecting their collective uncertainty, the Court dismissed the appeal as moot. ${ }^{215}$ Only Justice Douglas reached the merits; he agreed with Bickel and Kurland that the race-based preference should be subjected to strict scrutiny and invalidated. ${ }^{216}$ The issue returned to the Court when Allan Bakke challenged the racial quota program for admission to the University of California (Davis) School of Medicine. By 1978 , people's views on affirmative action had hardened, and it had

211. Brief of Amicus Curiae Anti-Defamation League of B'nai B'rith at 19, DeFunis v. Odegaard, 416 U.S. 312 (1974) (No. 73-235) [hereinafter Brief of Anti-Defamation League in DeFunis].

212. Brief of The Lawyers' Committee for Civil Rights Under Law as Amicus Curiae in Support of the Decision Below at 9-20, DeFunis v. Odegaard, 416 U.S. 312 (1974) (No. 73235); accord Brief of NAACP Legal Defense and Educational Fund, Inc., as Amicus Curiae, DeFunis (No. 73-235); Motion of the EEOC for Leave to File a Memorandum as Amicus Curiae and Memorandum, DeFunis (No. 73-235).

213. Brief of Anti-Defamation League in DeFunis, supra note 211, at 24 (citing Lino A. Graglia, Special Admission of the "Culturally Deprived" to Law School, 119 U. PA. L. REV. 351, 353-59 (1970)).

214. Id. at 25 (quoting ThOMAS SOWELl, BLACK EDUCATION, MYTHS AND TRAGEDIES 292 (1972)).

215. DeFunis, 416 U.S. at 319-20; cf. id. at 348 (Brennan, J., dissenting) (finding, with three other Justices, the case not moot).

216. Id. at 333-44 (Douglas, J. dissenting). 
become a highly polarizing issue: liberals were for it, whatever misgivings they had previously; conservatives were against it, as a violation of white people's rights and as a promotion of race divisions; and ambivalent moderates searched for mediating solutions that accommodated different interests and did not exacerbate racial divisions.

Accordingly, Regents of the University of California v. Bakke $e^{217}$ attracted more amicus briefs than any previous civil rights case, and the briefs were more apocalyptic than in DeFunis. The state and the amicus briefs for the ABA, ACLU, the NAACP, and various college and university groups emphasized the discretion universities needed to admit racial minorities for either remedial or diversity purposes. In an ironic twist, the Inc. Fund emphasized that judicial activism against affirmative action was inconsistent with the original intent of the Fourteenth Amendment's framers. ${ }^{218}$ The challenger and his amici (including Professor Kurland's brief for B'nai B'rith) argued that the quota system violated white men's equality rights and promoted race divisions.

A highly polarized Court agonized all term over Bakke (Section II.C.3). Its Solomonic resolution was delivered by Justice Powell, who subjected the race-based quota to strict scrutiny and invalidated it but with a roadmap that the government could use to craft policies that would pass muster. ${ }^{219}$ Powell accepted the preservationist arguments for strict scrutiny, namely, that race-based quotas not only violated white people's rights, but also promoted race animosity ${ }^{220}$ But he also accepted the civil rights argument that remediation of past discrimination or the attainment of a diverse student body could justify race-based affirmative action, albeit (for Powell) only if the program were narrowly tailored. ${ }^{221}$ Although Powell's solo opinion did not for-

217. 438 U.S. 265 (1978); see also Section II.C.3 (discussing Bakke). The leading account is BERNARD SCHWARTZ, BEHIND BAKKE: AFFIRMATIVE ACTION AND THE SUPREME Court (1988). See also Howard Ball, The BAKKE CASE: RaCe, EduCation, AND AFFIRMATIVE ACTION (2000); JEFFRIES, JUSTICE POWELL, supra note 171, at 455-501.

218. Brief of Amicus Curiae NAACP Legal Defense and Educational Fund, Inc. at 10 53, Regents of Univ. of Cal. v. Bakke, 438 U.S. 265 (1978) (No. 76-811). This is ironic because the Inc. Fund believed in a dynamic Equal Protection Clause and because the Justices most interested in original intent (Burger and Rehnquist) were least open to the Inc. Fund's position.

219. Technically, Powell delivered the judgment of the Court, but he spoke only for himself on the constitutional issue. Four Justices (Burger, Stewart, Rehnquist, Stevens) believed the preference program violated Title VI of the 1964 Civil Rights Act; four other Justices (Brennan, White, Marshall, Blackmun) believed the program consistent with both Title $\mathrm{VI}$ and the Constitution.

220. Bakke, 438 U.S. at 294-95 n.34 (Powell, J.).

221. Id. at 307-10 (accepting the remediation goal); id. at 311-15 (accepting the diverse student body goal). But see id. at 315-19 (finding that this odd quota program was not narrowly tailored to the diversity goal in Bakke's case). Procedurally, Powell made a point not suggested by the parties, that it ought to make a difference which governmental body 
mally resolve the affirmative action issue, it held out that possibility. A divided Court more or less followed Powell's roadmap in Fullilove $v$. Klutznick, ${ }^{222}$ which upheld a set-aside program for federal contracts to racial minorities. The Chief Justice's plurality opinion found the racial quotas defensible because they were adopted by Congress after full debate and persuasive findings that the program was needed to remedy past discrimination against minority contractors. ${ }^{223}$

An emboldened politics of preservation in the 1980 s challenged Powell's pragmatic compromise. Although traditionalist and civil rights groups generated few new arguments beyond those already developed in DeFunis and Bakke, ${ }^{224}$ the former gained ground politically and, as a result, judicially. The Reagan Administration's Solicitor General Charles Fried powerfully supported the critics of affirmative action in Wygant v. Jackson Board of Education ${ }^{225}$ and City of Richmond v. J.A. Croson Co. ${ }^{226}$ The Wygant brief is a preservationist classic. It led with the idea that affirmative action is an unfortunate retreat from the NAACP's correct argument in Brown that the Constitution " "prohibits a state from making racial distinctions in the exercise of governmental power.' "227 The NAACP's Inc. Fund, of

adopted the affirmative action program. Thus, an unelected group of administrators is not the most legitimate body to decide this important issue; the considered judgment, with factual findings, of a state or (better yet) national legislature is entitled to greater constitutional leeway. Id. at 308-10.

222. 448 U.S. $448(1980)$.

223. Id. at 475-77 (Burger, C.J., joined by White \& Powell, JJ.) (holding that Congress has authority to adopt set-aside legislation and its findings support the remediation of past discrimination goal); id. at 480-92 (finding that set-aside law's means are reasonably related to the remediation goal); id. at 496-517 (Powell, J., concurring) (explaining why the congressional set-aside program met all the procedural findings by a legitimate policy organ and substantive remediation requirements of his Bakke roadmap); see also id. at 517-21 (Marshall, J., joined by Brennan \& Blackmun, JJ, concurring) (federal program satisfies the intermediate scrutiny standard followed by these Justices in Bakke).

224. The briefs for all sides in Wygant v. Jackson Board of Education, 476 U.S. 267 (1989), City of Richmond v. Croson, 488 U.S. 469 (1989), and Adarand Constructors, Inc. v. Pena, 515 U.S. 200 (1995), were more voluminous, less original, and more repetitious than the briefs in the earlier cases. By the 1990 s, there were a number of talented empiricists working on affirmative action issues, but their work cut in several different directions and conclusions were mired in controversy. See, e.g., Symposium: The Law and Economics of Racial Discrimination in Employment, 79 GEO. L.J. 1619 (1991) (providing an excellent survey of, and contributing to, the empirical literature).

225. 476 U.S. 267 (1986).

226. 488 U.S. 469 (1989).

227. Brief for Amicus Curiae United States in Support of Petitioners at 4, Wygant v. Jackson Bd. of Educ., 476 U.S. 267 (1986) (No. 84-1340) (quoting Brief for Appellants in Nos. 1, 2, and 4 and Respondent in No. 10 at 21, Brown v. Bd. of Educ., 347 U.S 483 (1954)) [hereinafter U.S. Wygant Brief]. To the same effect was Brief for the United States as Amicus Curiae Supporting Appellee, City of Richmond v. J.A. Croson Co., 488 U.S. 469 (1989) (No. 87-998). 
course, did not believe its argument in Brown supported the same level of scrutiny for remedial racial preferences, to which Fried responded that a neutral-as-to-beneficiary approach was required by the original intent of the Fourteenth Amendment's framers, by the Court's precedents (starting with Hirabayashi and including the Court's sex discrimination precedents), and by the nation's political experience, which revealed that racial minorities were no longer politically powerless. ${ }^{228}$ In closing, Fried set the prestige of the Department of Justice behind Bickel and Kurland's "promotion of racism" argument - remedial preferences just as easily reinforce stereotypes and deepen hostility as reduce the same. ${ }^{229}$ The punch line: the state cannot use race-based preferences.

The Court struck down the racial preference in Wygant, but again, as in Bakke and Fullilove, without a majority opinion. Once four Reagan Justices were in place (Rehnquist [elevated to Chief Justice, 1986], O'Connor [1981], Scalia [1986], and Kennedy [1988]), there was a Court. Croson ruled that any race-based classification - whatever its motivation - would be subject to strict scrutiny and that the state can justify some race-based preference with nothing less than a showing that the underrepresentation of minorities is a product of past discrimination. ${ }^{230}$ Writing for the Court, Justice O'Connor concluded that generalized assertions of past discrimination constitute no sufficient justification for a race-based preference, and quotas are generally not reasonable remedies even when there has been a showing of past discrimination. ${ }^{231}$

The politics of preservation scored a further triumph in Adarand Constructors, Inc. v. Pena. ${ }^{232}$ Not only did a majority - the four Reagan Justices and Bush appointee Clarence Thomas - announce the same strict scrutiny for federal race-based set-aside programs, overruling or narrowing Fullilove, ${ }^{233}$ but Justices Scalia and Thomas issued statements urging a completely colorblind Constitution. Scalia's

228. See U.S. Wygant Brief, supra note 227 , at 8-10 (arguing that precedent requires the same approach); id. at 11-15 (arguing that original intent requires the same approach); id. at 16-20 (arguing that political theory requires the same approach).

229. Id. at 20-21.

230. Croson, 488 U.S. at 493-98 (O'Connor, J., joined by Rehnquist, C.J., and White \& Kennedy, JJ.); see id. at 520-25 (Scalia, J., concurring) (endorsing strict scrutiny as well, but stricter than O'Connor).

231. Id. at 498-99 (O'Connor, J., for the Court).

232. 515 U.S. 200 (1995).

233. See id. at 213-27. Justice O'Connor spoke for the Court here, except insofar as her opinion was inconsistent with Justice Scalia's concurrence. See id. at 239 (Scalia, J., concurring). Justice O'Connor's opinion for the Court, $i d$. at 227, overruled in part Metro Broadcasting Inc. v. FCC, 497 U.S. 547 (1990), which held that intermediate scrutiny is the standard required for judicial review of federal "benign" racial preferences. 
statement, "[i]n the eyes of the government, we are just one race here. It is American[,]"234 is half schmaltz, half inspiration. Thomas's was a new voice of color, giving greater authenticity to the promotion of racism argument: "racial paternalism and its unintended consequences can be as poisonous and pernicious as any other form of discrimination .... Inevitably ... [benign discrimination] programs engender attitudes of superiority or, alternatively, provoke resentment among those who believe that they have been wronged by the government's use of race. ${ }^{235}$

\section{B. Women's Rights Movements}

White women were disadvantaged differently than African Americans at the end of the nineteenth century. They were of course the largest group in the population. Men did not fear and hate them in the same way they feared and hated people of color; women were differently situated by biology in a way black men were not, for they and they alone bore the promise and the costs of pregnancy. Violence against white women was within the intimate reserves of the family, including marital rape and unwanted pregnancies. Where people of color were subordinated by the white supremacy ideology, enforced through public segregation and anti-miscegenation laws, women were subordinated by the ideology of separate spheres, enforced through their legal exclusion from voting, jury service, military service, and public and private employment. Black women, of course, suffered under both kinds of discrimination: they were denigrated by both apartheid and by women's exclusions. ${ }^{236}$ Also unlike the cause of civil rights, which seemed all but crushed in the first decades of the new century, women's causes were flourishing: the women's temperance movement won ratification of the Eighteenth Amendment instantiating Prohibition, and the Nineteenth Amendment gave women the right to vote in $1920 .{ }^{237}$ Yet once they had won the franchise, feminist

234. Adarand, 515 U.S. at 239 (Scalia, J., concurring in part and in the judgment).

235. Id. at 240-41 (Thomas, J., concurring in part and in the judgment).

236. See generally ANGELA Y. DAVIS, WOMEN, RACE, AND ClASS (1981); GLENDA GILMORE, GENDER AND JiM CROW (1996); ROSALYN TERBORG-PENN, AFriCAN AMERICAN WOMEN IN THE STRUGGLE FOR THE VOTE, 1850-1920 (1998).

237. On these remarkable but different feminist campaigns, see JOSEPH GUSFIELD, SYMBOLIC CRUSADE: STATUS POLITICS AND THE AMERICAN TEMPERANCE MOVEMENT (1986) (discussing the Eighteenth Amendment); Reva B. Siegel, She the People: The Nineteenth Amendment, Sex Equality, Federalism, and the Family, 115 HARV. L. REV. 947, 9601022 (2001) [hereinafter Siegel, She the People] (discussing the Nineteenth Amendment). 
politics went into partial hibernation, at exactly the same time when blacks were becoming more politically and constitutionally active..$^{238}$

Notwithstanding these and other differences, women's movements shared a core similarity with civil rights ones: their politics, including their constitutional politics, was driven by the traits (race and sex) that set them apart from "the norm" (white males). Like blacks, women objected that the state not only failed to protect them against private violence, but was itself an instrument of violence against them. Just as the state tolerated violence, including lynching, against black men, so it tolerated rape, including marital rape, against women. And the state was a direct instrument of violence against women insofar as it criminalized medical technologies by which women could control the terms of their pregnancies, specifically, the promulgation of articles of contraception and the practice of abortion. Like increasing numbers of black people, increasing numbers of women objected that the law unfairly disrespected them as well as denied them tangible opportunities. If apartheid laws effectively excluded people of color from full citizenship because of their race, sex-exclusionary laws did the same for women. The disrespect and exclusion were normatively indefensible: just as people of color ought to have all the opportunities and duties as white people, so women ought to have the same opportunities and duties as men. Sex, like race, is a benign variation, largely irrelevant to state policy.

Inspired by the successes of the civil rights movement, women engaged in a similar politics of recognition, sweeping away most state discriminations on the basis of sex in Supreme Court opinions of the 1970 s - at the very same time the country was debating and ultimately rejecting the Equal Rights Amendment. Also like the civil rights movement, the women's rights movement focused on issues of affirmative state remediation as soon as it had significantly achieved its equality goals; many of women's remedial measures have been successfully blocked by traditionalists, however. The biggest differences between the constitutional experiences of blacks and women relate to abortion. Although initially conceived as a matter of protecting women against health dangers and economic depletion, the politics of abortion was reconceived as a matter of women's equal citizenship, followed by the view that the state has an affirmative duty to provide women with support for their family planning choices. Viewing the fetus as a human person, the politics of preservation saw matters exactly the other way: its members were protecting fetuses, seeking recogni-

238. See NANCY F. COTT, THE GROUNDING OF MODERN FEMINISM 96-97 (1987); ELEANOR FleXNER, CENTURY OF STRUGGLE: THE WOMAN's RIGHTS MOVEMENT IN THE UNITED STATES 222-345 (2d ed. 1975); AILEEN S. KRADITOR, THE IDEAS OF THE WOMAN SUFFRAGE MOVEMENT, 1890-1920, at 261-64 (1965). 
tion of the value of human life, and opposing any policy that promoted abortion as a method of family planning.

\section{The Politics of Protection: Women's Control of Their Own Bodies, 1916-72}

After ratification of the Nineteenth Amendment, various politics of protection dominated public discourse about women's rights for the next half-century. There were three kinds of politics that sought to protect women against harm; only one of these was to emerge as a vigorous feminist politics, however. To begin with, there was a modest sexual politics that sought better enforcement of existing rape laws and reform of the many loopholes that effectively immunized much sexual assault from legal prosecution. Although rape reform was a matter of feminist and legislative attention throughout the twentieth century, ${ }^{239}$ it was not notably successful in changing the law to protect women's interests until the $1970 \mathrm{~s}^{240}$

In contrast, a paternalist politics of protection was highly successful, albeit ambiguously feminist. Such politics created special rules for women's participation in the workplace, protecting them and their families against dangerous or excessive work. ${ }^{241}$ Progressives successfully defended these laws against charges that they violated the liberty of contract judges found in the Due Process Clause. Less than three years after Lochner struck down a state law setting maximum hours for bakery employees, Muller v. Oregon ${ }^{242}$ evaluated a state law setting maximum hours for female employees. A unanimous Supreme Court

239. See generally SUSAN ESTRICH, REAL RAPE (1992) (tracing the slow evolution of rape law in the twentieth century); Jill Elaine Hasday, Contest and Consent: $A$ Legal History of Marital Rape, 88 CAL. L. REV. 1373 (2000) (detailing women's resistance to the criminal law's exemption for marital rape, starting in the nineteenth century but not successfully nullifying or even modifying such exemptions until the late twentieth).

240. See, e.g., People v. Liberta, 474 N.E.2d 567 (N.Y. 1984) (invalidating marital rape exemption as constituting an invidious discrimination against women and resting upon "archaic notions" of the family). See generally William E. Nelson, Criminality and Sexual Morality in New York, 1920-1980, 5 YALE J.L. \& HUMAN. 265, 301-11, 318-32 (1993) (providing a detailed case study of sex laws and women's interests in New York).

241. The classic description is Elizabeth Brandeis, Labor Legislation, in 3 HISTORY OF LABOR IN THE UNITED STATES, 1896-1932, at 399, 457-66 (John Commons ed., 1935). For modern feminist analyses critical of such laws, see JUDITH BAER, THE CHAINS OF PROTECTION: THE JUDICIAL RESPONSE TO WOMEN'S LABOR LEGISLATION (1978), and ALICE KESSLER-HARRIS, OUT TO WORK: A HISTORY OF WAGE-EARNING WOMEN IN THE UNITED STATES (1982). Also, compare Brief of Amici Curiae ACLU et al., California Saving \& Loan Ass'n v. Guerra, 479 U.S. 272 (1987) (No. 85-494) (critical of women's "protective" legislation), with Brief of Amici Curiae Coalition for Reproductive Equality in the Workplace et al., Guerra (No. 85-494) (supporting protective legislation when it remedies women's disadvantages in the workplace).

242. 208 U.S. 412 (1908). 
upheld the Oregon law, based upon the data presented in an amicus brief drafted by Louis Brandeis. The original "Brandeis brief" demonstrated not only that such protective legislation was universal in western culture, but that its rationale was a happy wedding of modern science and traditional mores: "The reasons for the reduction of the working day to ten hours - (a) the physical organization of women, (b) her maternal functions, (c) the rearing and education of the children, (d) the maintenance of the home - are all so important and so far reaching that the need for such reduction need hardly be discussed." "243 Justice Brewer's opinion for the Court ruled that women, like minors, should be treated by the courts "as needing especial care." 244

Most feminists as well as progressives supported this kind of protective legislation, but the voices of women were underrepresented and often absent in legislative debates and legal briefs. They could more often be found in the printed records of the cases. In Radice $v$. New York, ${ }^{245}$ involving a liberty of contract challenge to a law barring nightwork by women in urban restaurants, working class women testified at trial that such work was both congenial and necessary for them. "It is easier to work in a restaurant than it is to do housework." 246 The Court nevertheless upheld the law. After World War II, during which women did virtually every kind of work men had done and under similar circumstances, women spoke for themselves and often objected to laws cutting off economic opportunities for them. Attorney Anne Davidow challenged a Michigan law barring women from acting as bartenders unless they were wives or daughters of male owners in Goesaert $v$. Cleary. ${ }^{247}$ Two dozen women testified at trial that they were barmaids who needed the job to support families and were with-

243. Id. at $420 \mathrm{n} .1$ (quoting from the Brandeis brief); see id. at 421 (" $[\mathrm{H}]$ istory discloses the fact that woman has always been dependent upon man.").

244. Id. at 421. The Court later upheld similar statutes. See Radice v. New York, 264 U.S. 292 (1924) (Brandeis filed a brief as a supplement to the state's brief by Carl Sherman in this case); Miller v. Wilson, 236 U.S. 373 (1915) (Brandeis filed a brief in support of the state); Bosley v. McLaughlin, 236 U.S. 385 (1915) (same); see also Quong Wing v. Kirkendall, 223 U.S. 59 (1912) (upholding law exempting laundries run by women from a tax). The Court eventually struck down this line of "protective" reasoning in Adkins $v$. Children's Hospital, 261 U.S. 525 (1923) (Felix Frankfurter, Brandeis's protégé, filed a brief in support of the restrictive statute).

245. 264 U.S. 292 (1924).

246. Record on Appeal at 39, Radice v. New York, 264 U.S. 292 (1924) (1923 Term, No. 176) (testimony of Anna Schmitt). On redirect examination, Schmitt was asked, "There was nothing in the work which you did ... which a man could not have done, was there?" Id. at 41.

247. 335 U.S. 464 (1948). 
out other skills. ${ }^{248}$ Notwithstanding the seriousness of these women's plight and of Davidow's arguments, the Supreme Court spent only a few minutes discussing the case at conference. ${ }^{249}$ Justice Frankfurter's opinion for the Court treated the challenge as a lark, playfully recalling "the alewife, sprightly and ribald, in Shakespeare" and dishing off the women's challenges in three pages of the United States Reports. ${ }^{250}$ Nonetheless, Goesaert reflects the social fact that many women no longer considered such legislation truly "protective" of their interests.

At the same time some women were turning against the kind of "protective" legislation illustrated by Muller and Goesaert, a large number were turning against morals laws that laid much more striking burdens on women. Between 1850 and 1880, most states adopted laws criminalizing abortion. ${ }^{251}$ The federal Comstock Act of 1873 made it an obscenity crime to sell or distribute articles of contraception or abortion; to send such articles in the federal mail system; or to import such articles from abroad. ${ }^{252}$ By 1885 , twenty-four states had enacted their own versions of the Comstock Act, many of which were more stringent than the federal law. ${ }^{253}$ These laws bore harshly on women, who assumed most burdens of unwanted pregnancies. Many of those women mobilized in a politics of pregnancy that was both feminist (unlike some of the labor protections) and successful (unlike rape reform). The most articulate voices for their concerns were those of Emma Goldman and her follower Margaret Sanger. Goldman's philosophy was that women should have life opportunities of their own

248. Record on Appeal at 18-39, Goesaert v. Cleary, 335 U.S. 464 (1948) (1948 Term, No. 49).

249. I make the observation in text based upon the perfunctory comments in the conference notes for both Justices Douglas (who took detailed notes) and Burton.

250. Goesaert, 335 U.S. at 465-67. Davidow did win the votes of three dissenting Justices. Id. at 467-68 (Rutledge, J., dissenting).

251. See Janet Farrell Brodie, Contraception and Abortion in NineteEnthCENTURY AMERICA (1994); JAMES C. MOHR, ABORTION IN AMERICA: THE ORIGINS AND EVOlution OF NATIONAL POLICY, 1800-1900 (1978); LESLIE REAGAN, WHEN ABORTION WAS A Crime: WoMEN, MEdicine, AND LAW IN THE UNITED STATES, 1967-1973 (1997). For nineteenth century documents, see 2 ABORTION LAW IN THE UNITED STATES (Jenni Parrish ed., 1995).

252. 17 Stat. 598 (1873), codified at 18 U.S.C. \& 1461 et seq.; 19 U.S.C. $\$ 1305$ et seq. ("An Act for the Suppression of Trade in, and Circulation of, obscene Literature and Articles of immoral Use"). See generally BRODIE, supra note 251, at 255-56, 263-66, 281-88; HEYwOOD BROUN \& MARGARET LEECH, ANTHONY COMSTOCK: ROUNDSMAN OF THE LORD (1927); ROBERT W. HANEY, COMSTOCKERY IN AMERICA: PATTERNS OF CENSORSHIP AND CONTROL (1960).

253. See BRODIE, supra note 251, at 257 (stating that fourteen states barred any speech providing information on contraception and abortion; eleven states criminalized possession of such information; seventeen states barred doctors from discussing contraception with their patients); see also C. ThOMAs DiEnES, LAw, POLITICS, AND BIRTH CONTROL 33-48 (1972). 
choosing - and not those dictated by their fathers, husbands, children, or the state. ${ }^{254}$

If Goldman was the theorist of a new women's politics of claiming control over their own bodies, Sanger was the organizer and implementer ${ }^{255}$ The government censored both women: Goldman was deported for her antiwar speech in 1917; Sanger left the country after she was arrested for violating the Comstock Act in August 1914. ${ }^{256}$ The trial of her husband William in September 1915 for distributing copies of Woman Rebel inflamed public opinion sufficiently to impel the U.S. Attorney to drop all charges against Margaret, who returned triumphantly in $1916 .{ }^{257}$ She then opened the nation's first birth control clinic, in Brooklyn, New York. The New York police arrested Sanger and her sister, Ethel Byrne, for violating a pre-Comstock state law prohibiting circulation of "articles of indecent or immoral use," including articles "for the prevention of conception." ${ }^{258}$ The sisters were both convicted in well-publicized trials and went to jail as martyrs for the new cause.

The New York Court of Appeals affirmed Sanger's conviction, ${ }^{259}$ and she appealed to the U.S. Supreme Court. Jonah Goldstein's brief, including a supplement (compiled by Sanger) on the medical and sociological "Case for Birth Control," is a landmark in the history of women's rights litigation. The brief's central normative point was a wedding of women's sexual politics of rape and their politics of pregnancy: "The State has no more right to compel 'motherhood' than the

254. Emma Goldman, Marriage and Love (1910), reprinted in WOMEN's RIGHTS IN THE UNITED STATES: A DOCUMENTARY HISTORY 207-08 (Winston E. Langley \& Vivian C. Fox eds., 1994) (criticizing marriage because it "makes a parasite of a woman, an absolute dependent"); see BRODIE, supra note 251, at 36 (stating that Goldman advocated contraception because it would free women to enjoy sex without worrying about pregnancy); Hasday, supra note 239, at 1413-33 (finding the roots of Goldman's arguments in nineteenth-century feminism).

255. There are many excellent pieces on Sanger and the birth control movement. See ELLEN CHESLER, WOMAN OF VALOR: MARGARET SANGER AND THE BIRTH CONTROL MOVEMENT IN AMERICA (1992); LINDA GORDON, WOMAN'S BODY, WOMAN'S RIGHT: A SOCIAL HISTORY OF BIRTH CONTROL IN AMERICA (1976); DAVID M. KENNEDY, BIRTH CONTROL IN AMERICA: THE CAREER OF MARGARET SANGER (1970); JAMES REED, THE BIRTH CONTROL MOVEMENT AND AMERICAN SOCIETY: From PRIVATE VICE TO PUBLIC VIRTUE (1984). There are outstanding sources on the legal and litigation features of the birth control movement as well. See CHESLER, supra; DAVID J. GARROW, LIBERTY AND SEXUAlity: THE RIGHT TO PRIVACY AND THE MAKING OF ROE V. WADE 1-269 (1994) [hereinafter GARROW, LIBERTY AND SEXUALITY].

256. See CHESLER, supra note 255, at 99. In 1913, the Post Office refused to mail The Call because of Sanger's feminist libertarian column but relented after Sanger went to court with a First Amendment claim. See id. at 65-66.

257. See id. at $127-29,138-40$.

258. N.Y. Penal Law $\S 1142$.

259. People v. Sanger, 118 N.E. 637 (N.Y. 1918). 
individual to compel [sexual] relations." 260 The state's suppression of contraceptive devices and information was a severe and unacceptable intrusion into a married woman's personal liberty protected by the Due Process Clause. ${ }^{261}$ "In this enlightened age, when we are accustomed to listen to the discussion of the rights of women to economic freedom and independence ... does it not appear most unreasonable that she be deprived of the freedom of her person?"262 The brief also powerfully argued that the breadth of the state's prohibition was often a deprivation of life as well as liberty, because pregnancy for many women was life-threatening. By barring even dissemination of information that could be life-saving to these women, the state was placing their lives at risk. ${ }^{263}$ Finally, Goldstein's brief maintained that the statute was irrational in its effect and, therefore, unconstitutional even if no fundamental interest were involved. That is, the state's bar served no legitimate state interest and, indeed, undermined many legitimate ones, such as the health and safety of women, families, and children. ${ }^{264}$

Goldstein's and Sanger's massively documented and normatively charged brief was met by one argument from the state: the social and economic aspects of the birth control issue are subject to reasonable debate which should either be left to the legislature or should be resolved in favor of regulation, as most states and the federal government had precisely the same kind of laws. ${ }^{265}$ This argument apparently prevailed with the Supreme Court, which dismissed Sanger's appeal as raising no substantial federal question. ${ }^{266}$ The Lochner-era Court was not receptive to an interpretation of due process protecting sexual as opposed to family liberty. ${ }^{267}$ On the constitutional front, Sanger $v$. New

260. Brief on Behalf of the Plaintiff-in-Error at 31, Sanger v. New York, 251 U.S. 537 (1919) (1919 Term, No. 75) (emphasis in original); see id. at 39 ("[A] married woman has the fundamental right to determine whether she shall or shall not conceive and when she shall not conceive."); id. at 43 (stating that men and women have a "natural right to say how many children they will bring into the world and when").

261. See id. at 43-48 (relying on Lochner v. New York, 198 U.S. 45 (1905), among other authorities).

262. Id. at 45 .

263. See id. at 50-57; cf. id. at 51-52 (this problem is not solved by the statutory allowance for physicians to prescribe articles for the "cure or prevention of disease"). The brief argued that a law barring abortions would still violate the Due Process Clause if it did not include an exception for situations where the mother's life was at stake. Id. at 54-55.

264. See id. at 33-34 (arguing that "too frequent pregnancies" injure women's health and decrease the "virility of the children"); $i d$. at 35-36 (positing that the statutory bar to useful information leads many women to resort to celibacy and abortion, harmful to both women and society) $i d$. at 36-38 (statute contributes to poverty, overcrowding, illegitimacy, high infant mortality, and increased numbers of "unwanted" and "feeble-minded" children).

265. See Brief for Defendant-in-Error at 9-12, Sanger (1919 Term, No. 75).

266. Sanger v. New York, 251 U.S. 537 (1919) (per curiam).

267. See Buck v. Bell, 274 U.S. 200 (1927) (upholding state sterilization law). 
York failed in the short term. But the constitutional failure begat a statutory success, for in Sanger the New York Court of Appeals construed its state law as authorizing physicians to prescribe contraceptives for their patients to treat "disease," which the court broadly defined to include any "alteration in the state of body... [which] caus[ed] or threaten[ed] pain and sickness." 268 As a practical matter, that decision opened up a strategy by which birth control clinics could operate in New York, and Sanger created a clinic run by doctors in New York City and in 1922 founded the American Birth Control League. Harassment by authorities, and a raid by the police in 1929 , only fueled public support for the birth control movement. By 1935 , local leagues existed in more than half the states, and there were as many as 300 clinics, typically run by doctors. ${ }^{269}$

Because birth control advocates were not able to bestir Congress to repeal the federal Comstock Act, ${ }^{270}$ that law remained a potential problem, which activists attacked in court as violating the then-anemic First Amendment. Mary Dennett was prosecuted under the Comstock Act for mailing sex education materials. Following Morris Ernst's brief for Dennett, Judge Augustus Hand of the Second Circuit refused to interpret the statute to apply to "serious instruction regarding sex matters unless the terms in which the information is conveyed are clearly indecent." 271 Judge Swan applied similar reasoning to rule, in a trademark case, that contraceptives could be legally imported into the United States, so long as they might be capable of legitimate use. ${ }^{272}$ The judicial evisceration of the Act was completed in United States $v$. One Package. ${ }^{273}$ Judge Hand's opinion reasoned that Congress did not intend to bar importation of diaphragms by Dr. Hannah Stone, who ran Sanger's clinic in New York City; a doctor's goal of promoting health and saving lives was surely not "immoral" within the legislative intendment. ${ }^{274}$ The experience of birth control advocates with the Comstock Act was echoed at the state level: they were able to gain

268. People v. Sanger, 118 N.E. 637, 638 (N.Y. 1918) (quoting Webster's Dictionary).

269. See CHESLER, supra note 255, at 231.

270. On birth control advocates' inability to move Congress to repeal the Comstock Act, see id. at 232-33 (detailing Dennett's 1923 effort), and id. at 341-48 (detailing Sanger's 1934 effort).

271. United States v. Dennett, 39 F.2d 564, 569 (2d Cir.1930); see Appellant's Brief at 11-13, 32-33, Dennett (No. 238).

272. Youngs Rubber Corp. v. C.I. Lee \& Co., 45 F.2d 103 (2d Cir. 1930); see also Davis v. United States, 62 F.2d 473 (6th Cir. 1933) (following Youngs Rubber).

273. 86 F.2d 737 (2d Cir. 1936).

274. Id. at 739-40; $c f$. id. at 740 (Learned Hand, J., concurring) (remarking on the highly dynamic reading of the statute by his cousin). Again, the court's judgment carefully tracked Morris Ernst's Brief for Claimant-Appellee at 7-11, 19-23, 38, One Package (No. 62). 
administrative and judicial acquiescence of advice and distribution of contraceptives under the auspices of doctors' prescriptions. By the beginning of World War II, thirty-six states had medically-supervised birth control clinics supported at least in part by public funds, and another ten allowed such clinics to operate privately because of statutory loopholes allowing contraceptives by prescription. ${ }^{275}$

Sanger and her allies were not satisfied with this progress, in part because the medical-exception strategy left many poor and working class women, as well as single women, without sufficient access to contraceptives. Also, this strategy failed in Roman Catholic Connecticut and Massachusetts, whose judiciaries refused to construe their anticontraceptive statutes to allow a broad medical-needs exception. ${ }^{276}$ These decisions closed down the flourishing birth control clinics in those states, and activists resorted to constitutional claims, just as they had in response to earlier setbacks. In 1941, Dr. Wilder Tileston sued to nullify Connecticut's anti-contraception law on the ground that it unconstitutionally barred him from prescribing contraceptives needed to protect the health and lives of his female patients. The state courts rejected his claims on the merits, and the U.S. Supreme Court dismissed the constitutional appeal in Tileston $v$. Ullman, ${ }^{277}$ on the ground that the doctor had no standing to raise the life and liberty deprivations of his patients.

Planned Parenthood (as Sanger's birth control organization was renamed in 1942) of Connecticut remained interested in challenges to Connecticut's law. Director Estelle Griswold worked with Professor Fowler Harper of the Yale Law School and lawyer Catherine Roraback to bring a new challenge on behalf of several patients (including a married couple) and a doctor in Poe v. Ullman. ${ }^{278}$ Planned Parenthood, the ACLU, and several dozen doctors argued that the married couple enjoyed a right of privacy protecting their intimate relations. ${ }^{279}$ A majority of the internally fragmented Court went along with a per curiam opinion dismissing the appeal. Justices Douglas and

275. See Brief of Appellants app. C at 30, Tileston v. Ullman, 318 U.S. 44 (1943) (1942 Term, No. 420) (map of "States Having Contraceptive Services Under Medical Supervision").

276. State v. Nelson, 11 A.2d 856 (Conn. 1940); Commonwealth v. Gardner, 15 N.E.2d 222 (Mass. 1938); see also GARROW, LIBERTY AND SEXUALITY, supra note 255, at 44-78 (providing a detailed account of the litigation and strategic context of these cases).

277. 318 U.S. 44 (1943) (per curiam); see also GARROw, LIBERTY AND SEXUALITY, supra note 255, at 94-106 (providing a detailed account of the Tileston litigation).

278. 367 U.S. 497 (1961) (dismissing appeal of Buxton v. Ullman, 156 A.2d 508 (Conn. 1959)); see also GARROW, LIBERTY AND SEXUALITY, supra note 255, at $152-95$ (providing detailed account of the Poe litigation). Wade).

279. See Section II.B (discussing the briefs in Poe, Griswold, Eisenstadt, and Roe v. 
Harlan wrote impassioned dissenting opinions, arguing that there was a justiciable case and that the statute was unconstitutional. ${ }^{280}$

Poe's odd disposition was a bit of a fluke, and the Yale professors and Planned Parenthood pressed one final challenge. In 1965, the Supreme Court finally struck down the Connecticut contraception law in Griswold v. Connecticut. ${ }^{281}$ Five Justices joined Douglas's opinion for the Court, which carved a "zone of privacy" for married couples out of the "penumbras" of various guarantees in the Bill of Rights; ${ }^{282}$ three of the majority Justices also relied on the Ninth Amendment to support the recognition of a nontextual right of privacy, ${ }^{283}$ two Justices concurred in the judgment on the ground that the law deprived plaintiffs of their liberty without due process; ${ }^{284}$ and two Justices dissented. ${ }^{285}$ Notwithstanding the doctrinal diversity, at least six Justices spoke clearly to this effect: married couples have a fundamental right to plan their families and enjoy consensual sexual intercourse without interference from the state.

In spite of its narrow and offbeat reasoning, Griswold was a sensational vindication of Margaret Sanger's politics of protection. ${ }^{286}$ Massachusetts amended its law to allow married couples (but not single persons) to obtain contraceptives with a doctor's prescription. A divided Supreme Court expanded Griswold to strike down that state's discrimination between married and unmarried couples in Eisenstadt v. Baird. ${ }^{287}$ Justice Brennan's majority opinion for a seven-Justice Court ruled that, "[i]f the right of privacy means anything, it is the right of the individual, married or single, to be free from unwarranted governmental intrusion into matters so fundamentally affecting a person as the decision whether to bear or begat a child." 288 Even more

280. Poe, 367 U.S. at 509 (Douglas, J., dissenting); id. at 522 (Harlan, J., dissenting).

281. 381 U.S. 479 (1965); see also GARROW, LIBERTY AND SEXUALITY, supra note 255, at 196-269 (providing a detailed account of the Griswold litigation).

282. Griswold, 381 U.S. at 484 (Douglas, J., for the Court).

283. Id. at 486-99 (Goldberg, J., joined by Warren, C.J., and Brennan, J., concurring).

284. Id. at 500-02 (Harlan, J., concurring in the judgment); id. at 502-07 (White, J., concurring in the judgment).

285. Id. at 507-27 (Black, J., dissenting); id. at 527-31 (Stewart, J., dissenting).

286. On the very positive reception of the Griswold result and its privacy right, see, e.g., GARROW, LIBERTY AND SEXUALITY, supra note 255, at 263-67; Lackland H. Bloom, Jr., The Legacy of Griswold, 16 OHIO N.U.L. REV. 511, 527 (1989); Symposium on the Griswold Case and the Right of Privacy, 64 MICH. L. REV. 197 (1965). Between 1963 and 1965, popular support for the proposition, "Should birth control information be available to anyone that wants it?," went up from $74 \%$ to $81 \%$ (from $53 \%$ to $78 \%$ among Catholics). GEORGE H. GaLluP, THE GALLUP POLL, 1935-1971, at 1823, 1915-16 (1972).

287. 405 U.S. 438 (1972).

288. Id. at 453. Brennan spoke for himself and Justices Douglas, Stewart, and Marshall. Justices White and Blackmun concurred in the result on narrow grounds, and Chief Justice Burger dissented. (Newly appointed Justices Rehnquist and Powell did not participate.) 
momentous was Griswold's effect on another dimension of women's maturing politics of protection: the right not only to prevent pregnancy, but also to terminate it.

Many early birth control advocates (including Goldman and Sanger) had personally favored a woman's freedom to choose abortion, but that issue was purposely downplayed in the campaign to liberalize contraception laws. ${ }^{289}$ During the 1950 s and 1960 s, there was growing interest in liberalizing nineteenth century abortion laws, and by the late 1960s large numbers of women and doctors were organized as a new "pro-choice" movement for repeal rather than just liberalization of laws prohibiting abortions. ${ }^{290}$ Unlike the birth control movement, the pro-choice movement achieved immediate successes in some state legislatures, in part because large numbers of women were allied with the medical establishment (whose members feared prosecution under the older laws). By 1970, four states - Hawaii, Alaska, New York, and Washington - had decriminalized abortion, and twelve others (including California) had liberalized their laws. Buoyed by Planned Parenthood's success in the courts, the pro-choice movement immediately sought to constitutionalize its members' claims. Courts all over the United States read Griswold to protect single women seeking to abort unwanted pregnancies. Abortion statutes - liberalized laws as well as archaic ones - fell right and left. ${ }^{291}$

The Supreme Court granted review in two of the cases, one involving Texas's nineteenth century law, which had no exception for the mother's health, and one involving Georgia's recent law, allowing abortions if approved by the mother's doctor and two others on a hospital panel. Sarah Weddington, the lawyer for "Jane Roe" in the Texas

289. See Brief on Behalf of the Plaintiff-in-Error at 35, Sanger v. New York, 251 U.S. 537 (1919) (1919 Term, No. 75) (arguing that anti-contraception laws lead to more "dangerous abortions"); Morris Ernst \& Harriet Pilpel, Release from the Comstock Era, BIRTH CONTROL REV., Dec. 1939 at 24 (sharply distinguishing abortion as "the antithesis of contraception").

290. There is a formidable literature on the evolving legislative and judicial campaigns of the early pro-choice movement. See GARROW, LIBERTY AND SEXUALITY, supra note 255, at 270-334 (providing an account of early voices, from 1933 to 1967); id. at 335-88 (providing an account from reform to repeal, 1967 to 1969); LAWRENCE LADER, ABORTION II: MAKING THE REVOLUTION (1973); KRISTIN LUKER, ABORTION AND THE POLITICS OF MOTHERHOOD (1984); ROSEMARY NOSSIFF, BEFORE ROE: ABORTION POLICY IN THE STATES 35-37, 65-68 (2001) (examining the different tactics of the ALI, NOW, and radical feminists); SuZANne STAGgENBORG, THE PRO-CHOICE MOVEMENT: ORGANIZATION AND ACTIVISM IN THE ABORTION CONFLICT (1991); REAGAN, supra note 251, at 216-34.

291. See Abele v. Markle, 369 F. Supp. 807 (D. Conn. 1973); Doe v. Scott, 321 F. Supp. 1385 (N.D. Ill. 1971); Roe v. Wade, 314 F. Supp. 1217 (N.D. Tex. 1970), affd, 410 U.S. 113 (1973); Doe v. Bolton, 319 F. Supp. 1048 (N.D. Ga. 1970), aff'd in part, 410 U.S. 179 (1973); People v. Belous, 458 P.2d 194 (Cal. 1969), cert. denied, 397 U.S. 915 (1970): see also United States v. Vuitch, 305 F. Supp. 1032 (D.D.C. 1969) (striking down D.C. abortion law as vague), rev'd, 402 U.S. 62 (1971) (upholding statute based upon liberal construction of allowance for abortion to protect mother's "health"). 
case, argued that "pregnancy to a woman is perhaps one of the most determinative aspects of her life. It disrupts her body. It disrupts her education. It disrupts her employment." Because of this impact, this is a "matter which is of such fundamental and basic concern to the woman... that she should be allowed to make the choice as to whether to continue or terminate her pregnancy." ${ }^{292}$ The state objected that the controversy was not justiciable and, if justiciable, that the rights of the human fetus trumped those of the mother. ${ }^{293}$ After reargument, the Supreme Court achieved a surprising consensus. Justice Blackmun's opinion for a seven-Justice Court ruled in Roe v. Wade ${ }^{294}$ that the Texas law unconstitutionally burdened a woman's due process liberty to control her body and choose an abortion in the first trimester. In Doe v. Bolton, ${ }^{295}$ Justice Blackmun's opinion focused on the decision of the mother made in consultation with her doctor and struck down most of the other procedural and substantive obstacles Georgia's recent law imposed on the mother. The Court's decisions in the abortion cases were an international sensation, but for my purposes they are the near-apotheosis of women's politics of protection as it concerned pregnancy: after 1973, the constitutional baseline was that a woman is, as a matter of constitutional law, the primary decisionmaker as to issues of conceiving and bearing a child.

\section{Feminists' Politics of Recognition, 1961-76}

Like people of color, but more successfully, women engaged in a vigorous politics of recognition during the late nineteenth century. ${ }^{296}$ Unlike people of color's, their politics won some notable victories early in the twentieth. The Nineteenth Amendment was adopted against traditionalist arguments that women's role should be limited to the domestic sphere, and it advanced the norm that women's abilities were on a par with men's. ${ }^{297}$ The early birth control movement was part of such a politics. Emma Goldman maintained that

292. Oral Argument, Roe v. Wade, 410 U.S. 113 (1973), in 75 LANDMARK BRIEFS, supra note 199, at 787; see Brief for Appellants at 99-115, Roe v. Wade, 410 U.S. 113 (1973) (No. 70-18); see also id. at $94-99$ (relying on a right to receive medical care for the protection of the mother's health as well).

293. Brief for Appellee at 9-20, Roe (No. 70-18) (arguing that the issue is nonjusticiable); $i d$. at 26-54 (arguing that the rights of the fetus trump those of the mother).

294. 410 U.S. 113 (1973); see also Sections II.A.3 \& II.B (discussing the Court's deliberations in Roe). See generally GARROW, LIBERTY AND SEXUALITY, supra note 255, at 389-599 (providing a detailed account of the Roe litigation and the Court's internal deliberations).

295. 410 U.S. 179 (1973).

296. See Ellen Carol Du Bois, Outgrowing the Compact of the Fathers: Equal Rights, Woman Suffrage, and the United States Constitution, 1820-1878, 74 J. AM. HIST. 836 (1987).

297. See Siegel, She the People, siupra note 237. 
[a woman's] development, her freedom, her independence, must come from and through herself. First, by asserting herself as a personality, and not as a sex commodity. Second, by refusing to bear children, unless she wants them, by refusing to be a servant to God, the State, society, the husband, the family etc., by making her life simpler, but deeper and richer. ${ }^{298}$

Potentially important for women's politics of recognition was the proposed Equal Rights Amendment ("ERA"), first introduced in Congress in 1923. Yet many feminists were appalled by Goldman's call for sexual liberation and opposed the ERA on the grounds that it would preempt labor-protective legislation ${ }^{299}$ or wrongfully denied women's genuine difference from men. ${ }^{300}$ These were among the reasons the feminist politics of recognition stalled or slowed down after the Nineteenth Amendment. ${ }^{301}$ It did not disappear, however. The ERA continued to be debated among feminists and within Congress in the $1940 \mathrm{~s}$ and $1950 \mathrm{~s} .^{302}$ Most states eased their exclusions of women from juries, either placing their service on a par with men's or allowing them to serve unless they opted out. Although masked for the most part during the $1930 \mathrm{~s}$, the birth control movement continued to be animated, in part, by an insistence that women have the freedom that Goldman had asserted.

Women's politics of recognition picked up speed after World War II, and the renewed interest showed up immediately in constitutional cases such as Goesaert. ${ }^{303}$ Women who had proved themselves fully equal to men during the war were often unwilling to re-assume their subordinate status after the war. In constitutional law, this attitude was displayed most clearly in the cases challenging women's exclusion or exemption from jury service. Women generally did not serve on ju-

298. Emma Goldman, Woman Sufferage, WOMAN REBEL, June 1914, at 4; see also CANDACE FALK, LOVE, ANARCHY, AND EMMA GOLDMAN (1985); EMMA GOLDMAN, The Tragedy of Woman's Emancipation, in ANARCHISM AND OTHER ESSAYS 219, 237 (1910).

299. The League of Women's Voters and the Women's Bureau opposed the ERA for this reason. GLADYS HARRISON, NATIONAL. LEAGUE OF WOMEN VOTERS, Against "EQUAL RIGHTS" BY CONSTITUTIONAL AMENDMENT 11-12 (1928); see RUTH ROSEN, THE WORLD SPLIT OPEN: HOW THE MODERN WOMEN'S MOVEMENT CHANGED AMERICA 27, 66 (2000) [hereinafter ROSEN, THE WORLD SPLIT OPEN].

300. See Josephine Donovan, Feminist Theory: The InTEllectual Traditions OF AMERICAN FEMINISM 75-76 (2001); Katherine M. Franke, The Central Mistake of Sex Discrimination Law: The Disaggregation of Sex From Gender, 144 U. PA. L. REV. 1, 16 (1995).

301. See generally Verta Taylor, Social Movement Continuity: The Women's Movement in Abeyance, 54 AM. Soc. REV. 761 (1989).

302. See Cynthia harrison, On Account of Sex: The Politics of Women's ISSUES, 1945-1968, at 3-38 (1988) [hereinafter HARRISON, ON ACCOUNT OF SEX].

303. Anne Davidow's brief in that case argued that the barmaid law was an "unfair discrimination against women owners of bars" and "women bartenders." Brief of Appellants at 6, Goesaert v. Cleary, 335 U.S. 464 (1948) (1947 Term, No. 49). 
ries before World War I. Once women gained the right to vote, some state courts construed their state jury service laws to include women because the laws tied jury venires to voting lists. Nonetheless, as the nation entered World War II, only thirteen states required the same jury service of women that they required of men; fifteen states allowed women to opt out of compulsory jury service; twenty states disqualified women as a class. ${ }^{304}$

After the war, the situation shifted rapidly, and the Supreme Court gave it a push in 1946. Relying on a federal statute; the Court overturned the conviction of Edna and Donald Ballard for promotion of a fraudulent religious program, because the federal judge excluded women from the jury venire in Ballard v. United States. ${ }^{305}$ In response to the government's argument that the admittedly erroneous discrimination was not prejudicial to defendants' jury trial rights, Justice Douglas responded that women and men are "not fungible; a community made up exclusively of one is different from a community composed of both." He then posed the question: "[I]f the shoe were on the other foot, who would claim that a jury was truly representative of the community if all men were intentionally and systematically excluded from the panel?" ${ }^{306}$ A Court majority declined to constitutionalize that principle in Fay v. New York ${ }^{307}$ but four dissenters in that case maintained that a "blue ribbon" jury substantially excluding women and working class people violated the Equal Protection Clause. ${ }^{308}$

After Ballard and Fay, the complete exclusion of women dropped away. By 1961, only three states retained complete exclusions. Of the forty-seven states where women were eligible, twenty-one states had no special gender-based rules, eight states allowed women to be excused if their service would create hardships for their families, fifteen states and the District of Columbia allowed women to opt out for any reason, and three states permitted women to serve only if they opted in. ${ }^{309}$ Gwendolyn Hoyt killed her husband in Florida, one of the states in the last group. A jury of twelve men found her guilty of murder, and

304. REPORT TO THE JUdiCIAL CONFERENCE OF THE COMMITTEE ON SELECTION OF JURORS 23 (1942), noted in Fay v. New York, 332 U.S. 261, 289 \& n.31 (1947).

305. 329 U.S. 187 (1946).

306. Id. at 193. The federal statute, 28 U.S.C. $\$ 411$, required that jurors in federal court should have the same qualifications as those of the state in which the court was sitting (California, which did allow women to serve on juries). The Court had construed the statute as reflecting a design to make the jury "a cross-section of the community" and representative of it. Glasser v. United States, 315 U.S. 60, 86 (1942).

307. 332 U.S. 261 (1947).

308. Id. at 296-300 (Murphy, J., joined by Black, Douglas \& Rutledge, JJ., dissenting).

309. See Hoyt v. Florida, 368 U.S. 57, $62-63$ (1961). For more background, see LINDA K. KeRBER, No CONSTITUTIONAL Right TO BE LADIES (1998). 
she appealed on the ground that the Equal Protection Clause prohibited the exclusion of women from the jury that convicted her. Her counsel on appeal argued that Ballard's federal statutory rule should be extended to the states as a matter of equal protection; the state's reason for continuing to excuse women - their families' need for them - was wholly inapplicable to the one-third of Florida women who worked outside the home..$^{310}$

Dorothy Kenyon persuaded the ACLU to befriend Hoyt on the appeal, the Union's first major feminist Supreme Court filing. ${ }^{311} \mathrm{Her}$ remarkable amicus brief argued that representation on juries is an important civil right, as illustrated by the experience of blacks, who did not achieve genuine citizenship until the Court required that they be invited to its burdens such as jury service. ${ }^{312}$ The same was true of women. They continued to be excluded, either by law or in practice, because "the thinking of older times, when women were no part of the body politic," suggested that jury service would detract from women's "primary duties" of housekeeping and childrearing. This rationale was decidedly anachronistic, as "a revolution has taken place in the lives and status of women." ${ }^{\text {"313 }}$ Not only was the discrimination against all women therefore unreasonable, but it was a discrimination that the "fully emancipated, fully enfranchised woman citizen" would no longer tolerate:

It is a belittlement of her accomplishment in overcoming that long time sex defect of hers to suggest, even by implication, that even in this day and age she is perhaps still not qualified or capable of performing this simple act of good citizenship on the same terms as men. It is a genuine humiliation and degradation of her spirit. ${ }^{314}$

Kenyon's brief epitomizes what I am calling women's politics of recognition: in demanding equal respect, women were demanding the same duties as well as benefits that men had and insisted on complete rather than token integration into the public as well as private institutions of the nation.

The Warren Court did not see matters this way. At conference, the Chief Justice presented a diluted version of Kenyon's arguments and 31).

310. Brief for Appellant at 10-19, Hoyt v. Florida, 368 U.S. 57 (1961) (1961 Term, No.

311. See Susan M. Hartmann, The Other feminists: Activists In the Liberal ESTABLISHMENT 53-71 (1998) (noting that Kenyon, an ACLU board member for forty years, was the only voice of feminism in the organization from 1930 until she was joined by Harriet Pilpel in 1962 and Pauli Murray in 1965).

312. Brief of Amici Curiae Florida Civil Liberties Union and American Civil Liberties Union at 8-12, Hoyt (1961 Term, No. 31).

313. Id. at 20.

314. Id. at 26. 
urged reversal on the ground that Florida's opt-in system generated juries that were ridiculously unbalanced under the Ballard criteria. ${ }^{315}$ Justices Black and Douglas immediately agreed, but the remainder of the Court went with Justices Frankfurter and Whittaker, who maintained that there was "no systematic exclusion" of women similar to that found in Ballard or the Norris line of cases. ${ }^{316}$ Frankfurter smartly assigned the case to Justice Harlan, the finest lawyer on the Court. His opinion in Hoyt $v$. Florida $a^{317}$ was a masterly treatment of the largely uncharted issue of how to handle sex-based classifications and of the much-litigated issue (in the race cases) of discriminatory application of a statutory standard. Even the dissenters in conference felt impelled to join part of Harlan's opinion. ${ }^{318}$ In this fashion, the Warren Court was unanimous in denying women's incipient politics of recognition in what turned out to be that Court's only important sex discrimination case.

Hoyt cast into bold relief the fact that the Supreme Court had never struck down a sex discrimination as unconstitutional. ${ }^{319}$ Ironically, the decision came just as the women's movement was taking flight again. Responding to mounting feminist demands, President Kennedy in 1961 established the President's Commission on the Status of Women, which served as a consciousness-raising and idea-sharing forum for feminist lawyers and thinkers from all around the country. ${ }^{320}$ Pauli Murray, a civil rights lawyer working toward her J.S.D. at Yale Law School, drafted a remarkable memorandum for the Commission. The memorandum argued that the Equal Protection Clause could be interpreted to question sex-based discrimination for the same reasons the Court had deployed it against race-based discrimination: sex discrimination (like race discrimination) rested upon a natural law understanding of "inherent differences" that had been deployed to support disadvantages and social inferiority of women; the naturalized view of sex differences rested upon unproven stereotypes or myths about

315. See Douglas Conference Notes for Hoyt v. Florida (Oct. 20, 1961), in Douglas Papers, supra note 192, Container 1269.

316. See id. Justice Brennan was a "tentative" vote for affirmance along those grounds.

317. 368 U.S. 57 (1961).

318. See id. at 69 (Warren, C.J., and Black \& Douglas, JJ., concurring in part).

319. Contrast Ballard, 329 U.S. 187 (1946), where the Court struck down a total exclusion of women in a federal proceeding because it violated a federal statutory mandate, with Fay, 332 U.S. 261 (1947) (later in the 1946 Term), where the Court upheld against equal protection attack a substantial exclusion of women in a state proceeding, and Hoyt, 368 U.S. 57 (1961), where the Court continued to follow Fay even after most states had adopted inclusionary policies. But $c f$. White v. Crook, 251 F.Supp. 401 (M.D. Ala. 1966) (three-judge court) (striking down Alabama's exclusion of all women from juries; distinguishing Hoyt as involving unproven charges of de facto discrimination).

320. See HARRISON, ON ACCOUNT OF SEX, supra note 302, at 109-37. 
women that were usually an irrational basis for subordinating them; like blacks, women needed to mobilize against pervasive state discrimination through the formation of an organization like the NAACP. ${ }^{321}$

Murray's arguments not only persuaded the President's Commission that "[e]quality of rights under the law for all persons, male or female, is so basic to democracy and its commitment to the ultimate value of the individual that it must be reflected in the fundamental law of the land,"'322 but also helped persuade the ACLU to add sex equality to its civil rights agenda. ${ }^{323}$ Moreover, Murray's memorandum served to bridge the concerns of various civil rights activists: her Fourteenth Amendment strategy sought equality for women (desired by liberal ERA feminists), but without sacrificing laws genuinely remedying women's disadvantages in the workplace (desired by labor feminists and ERA opponents). For good measure, Murray, an African American who had been active in the civil rights movement, sought to unite blacks and women in a common campaign against prejudice and discrimination. ${ }^{324}$

Murray's arguments found their way into the congressional debates over the addition of "sex discrimination" to the jobs title of the Kennedy Administration's civil rights bill. Although the addition was propounded by anti-civil rights (but pro-ERA) Representative Howard Smith of Virginia, Murray and other feminists supported it and ensured that it was preserved in the final statute. ${ }^{325}$ The EEOC,

321. Pauli Murray, A Proposal to Reexamine the Applicability of the Fourteenth Amendment to State Laws and Practices Which Discriminate on the Basis of Sex Per Se (Dec. 1962), in President's Commission on the Status of Women Papers, Schlesinger Library [Radcliffe Inst.], Box 8, Folder 62, discussed in HARRISON, ON ACCOUNT OF SEX, supra note 302, at 126-34; Mary Becker, The Sixties Shift to Formal Equality and the Courts: An Argument for Pragmatism and Politics, 40 WM. \& MARY L. REV. 209, 222-31 (1998). (1963).

322. PRESIdent's COMMISSION ON THE Status OF WOMEN, AMERICAN WOMEN 44-45

323. Dorothy Kenyon in 1963 presented Murray's memo (whose arguments paralleled those she had pressed in Hoyt) to the ACLU board, which was supportive. HARTMANN, supra note 311, at 62-63. Murray joined the board in 1965, id. at 54, and she and Kenyon in 1966 urged the ACLU to go on record against legislation classifying on the basis of sex as "inherently discriminatory and unconstitutional." Id. at 72. Although they attracted allies within the ACLU (Norman Dorsen and Mel Wulf), they were not able to persuade the board to support constitutional equality for women until 1970 , from which followed the establishment of the Women's Rights Project. Id. at 80-83; see also Nadine Strossen, The American Civil Liberties Union and Women's Rights, 66 N.Y.U. L. REV. 1940, 1950-55 (1991) (describing the origins of the ACLU's role in women's rights litigation).

324. See Pauli Murray \& Mary O. Eastwood, Jane Crow and the Law: Sex Discrimination and Title VII, 34 GEO. WASH. L. REV. 232 (1965); Serena Mayeri, Note, "A Common Fate of Discrimination": Race-Gender Analogies in Legal and Historical Perspective, 110 YALE L.J. 1045 (2001).

325. See HARrison, ON ACCOUNT OF SEX, supra note 302, at 176-82; PAUli MURRAY, The Autobiography of a BlaCk ACTIVIST, FEMINIST, LAWYER, PRIEST, AND POET 
however, refused to make sex discrimination a priority in its enforcement of the new law, a stance that drew strong protests. When officials ignored their complaints at a 1966 conference on women's status, Murray, Betty Friedan, and other feminists stormed out in protest and founded the National Organization for Women ("NOW"). As Friedan later recalled, "it only took a few of us to get together to ignite the spark" that grassroots feminist consciousness raising had already created, "and it spread like a nuclear chain reaction." ${ }^{326}$ In its statement of purpose, NOW went beyond the ambivalent agenda of the President's Commission and demanded not just formal equality for women, but also a dismantling of the separate spheres ideology. Women should not only have all the (public) economic and social opportunities as men, but men should also share in the (private) responsibilities of home and childrearing. ${ }^{327}$ In 1967, NOW set out an ambitious national agenda, including serious enforcement of the Equal Pay Act and Title VII by the EEOC and the courts; adoption of the ERA; and repeal of abortion laws. ${ }^{328}$ As Cynthia Harrison has argued, NOW's agenda reflected the first coherent feminist philosophy of the century, one that combined an updated politics of protection with a new politics of recognition: childbearing should be separated from both sexual intimacy and from childrearing; both mothers and fathers are responsible for family as well as work. ${ }^{329}$

Like the NAACP, NOW established a Legal Defense and Education Fund to litigate issues of women's equality. In 1971, the ACLU established its Women's Rights Project, headed by Professor Ruth Bader Ginsburg. Representing a new generation of litigators, Ginsburg followed Kenyon and Murray in pressing the Court to rule that women have all the same legal rights and duties as men. ${ }^{330}$ These

354-58 (1987); Jo Freeman, How "Sex" Got into Title VII: Persistent Opportunism as a Maker of Public Policy, 9 LAW \& INEQUALITY 163, 163-84 (1991).

326. JUDITH HOLE \& ELLEN LEVINE, REBIRTH OF FEMINISM 81 (1971) (quoting Betty Friedan, N.O.W. - How It Began, WoMen SPEAKING, Apr. 1967, at 4). See generally Caroline Bird, Born Female: The High Cost of KeEPING Women Down 209 (rev. ed. 1970); Jo Ann Freeman, The Origins of the Women's Liberation Movement, 78 AM. J. SOC. 792 (1973).

327. NOW, Statement of Purpose, reprinted in UP FROM THE PEDESTAL: SELECTED WRITINGS IN THE HistORY OF AMERICAN FEMINISM 363-69 (Aileen S. Kraditor ed., 1968).

328. HARRISON, ON ACCOUNT OF SEX, supra note 302, at 201-05. At the same time NOW was pressing this national agenda, it was encouraging local "consciousness raising" groups among women and activism at the local level. See SARA EVANS, PERSONAL POLITICS: THE ROOTS OF WOMEN'S LIBERATION IN THE CIVIL RIGHTS MOVEMENT AND THE NEW LEFT (1979).

329. HARRISON, ON ACCOUNT OF SEX, supra note 302, at 217.

330. That their voice became the voice of women before the Court does not mean that all women agreed with their philosophy; both traditionalist and radical female perspectives were generally not heard by the Court until the 1980s. Compare F. CAROLYN Graglia, THE Housewife as PARIAH: CONTEMPORARY FEMINISM'S WAR ON THE FAMILY (1997) 
lawyers filed constitutional challenges to statutory sex discriminations, and state and federal judges found many of the challenged policies unconstitutional - notwithstanding Hoyt. The leading case was White $v$. Crook, where Dorothy Kenyon and Pauli Murray's ACLU brief helped persuade a three-judge federal court to hold invalid Alabama's exclusion of both people of color and women from criminal juries. ${ }^{331}$ For examples at the state level, the New Jersey and California Supreme Courts struck down state exclusions of women from bartending, essentially refusing to follow Goesaert. ${ }^{332}$ Several state courts overruled the common law presumption that only husbands could bring loss of consortium claims in tort, on the ground that this was a blatant sex discrimination. ${ }^{333}$ Federal judges struck down state laws excluding women from state universities, ${ }^{334}$ from living off campus at state colleges, ${ }^{335}$ and from juries, ${ }^{336}$ as well as state laws treating women differently from men for purposes of sentencing after conviction of a crime. ${ }^{337}$

The first case to reach the U.S. Supreme Court was an ACLU challenge to an Idaho statute which preferred male relatives over female ones for purposes of appointment to administer estates of intestate decedents. Sally Reed's counsel on appeal - Kenyon, Murray, Wulf, and Ginsburg - urged the Court to renounce the constitutional philosophy of Muller, Goesaert, and Hoyt. ${ }^{338}$ "[A] new appreciation of women's place has been generated in the United States." Feminists "of both sexes" had pressed for women's "full membership" in the benefits and duties of constitutional citizenship. "But the distance to equal opportunity for women - in the face of the pervasive social,

(discussing exclusion of traditionalist women from feminist thinking), with IMELDA WHELEHAN, MODERN FEMINIST THOUGHT $69-79$ (1995) (discussing exclusion of radical feminists from legal reformist efforts).

331. 251 F. Supp. 401 (M.D. Ala. 1966) (three-judge court) (not appealed).

332. Sail'er Inn, Inc. v. Kirby, 485 P.2d 529 (Cal. 1971); Paterson Tavern \& Grill Owners Ass'n v. Borough of Hawthorne, 270 A.2d 628 (N.J. 1970); Gallagher v. City of Bayonne, 245 A.2d 373 (N.J. 1968); see also Seidenberg v. McSorleys' Old Ale House, 317 F. Supp. 593 (S.D.N.Y. 1970) (exclusion of female patrons unconstitutional).

333. Deems v. Western Md. Ry. Co., 231 A.2d 514 (Md. 1967); Montgomery v. Stephen, 101 N.W.2d 227 (Mich. 1960); Millington v. Southeastern Elevator Co., 239 N.E.2d 897 (N.Y. 1968); Durham v. Gabriel, 241 N.E.2d 401 (Ohio 1968); Clem v. Brown, 207 N.E.2d 398 (Ohio 1965).

334. Kirstein v. Rector \& Visitors of the Univ. of Va., 309 F. Supp. 184 (E.D. Va. 1970) (three-judge court).

335. Mollere v. Southeastern La. College, 304 F. Supp. 826 (E.D. La. 1969).

336. Abbott v. Mines, 411 F.2d 353 (6th Cir. 1969); White v. Crook, 251 F.Supp. 401 (M.D. Ala. 1966) (three-judge court).

337. United States ex rel. Robinson v. York, 281 F. Supp. 8 (D. Conn. 1968); accord Liberti v. York, 246 A.2d 106 (Conn. 1968); Commonwealth v. Daniel, 243 A.2d 400 (Pa. 1969).

338. Brief for Appellant at 41-53, Reed v. Reed, 404 U.S. 71 (1971) (No. 70-4). 
cultural, and legal roots of sex-based discrimination - remains considerable. In the absence of a firm constitutional foundation for equal treatment of men and women by the law, women seeking to be judged on their individual merits will continue to encounter law-sanctioned obstacles." 339 Accordingly, the ACLU lawyers maintained that sex was a suspect classification for the same reasons race was: both were natural traits that the dominant culture has treated as a badge of inferiority and stigmatized legally, based upon inaccurate stereotypes about the group defined by the trait. ${ }^{340}$

At the urging of Professor Herma Hill Kay, the California Supreme Court had just accepted such an argument in Sail'er Inn, Inc. v. Kirby. ${ }^{341}$ But the U.S. Supreme Court was not prepared to go that far in 1971, nor did the case require it to do so. As Chief Justice Burger said in opening the short conference discussion, the statute was a "carry over from [an] ancient English statute" and "can't stand" because it was an unreasonable discrimination, as the ACLU had also argued ${ }^{342}$ Burger's opinion for a unanimous Court in Reed $v$. Reed ${ }^{343}$ rested upon the statute's arbitrariness and therefore left the ACLU's other arguments unaddressed. In Forbush $v$. Wallace, ${ }^{344}$ the Court suggested it was still applying ordinary review to sex-based classifications, as it summarily affirmed a lower court decision upholding state rules requiring women to adopt their husbands' surnames when they married.

Soon after Reed and Forbush, Congress voted for the proposed ERA and sent it to the states for ratification. This was an important normative moment, for not only did feminists unite behind the proposal, but huge bipartisan majorities in Congress agreed that "Equality of rights under the law shall not be denied or abridged by the United States or any State because of sex." 345 Meanwhile, Fourteenth

339. $I d$, at 10 .

340. Id. at 14-41; accord, Joint Brief of Amici Curiae American Veterans Comm., Inc., NOW Legal Defense \& Education Fund, Inc. at 10-12, Reed (No. 70-4); Brief of the City of New York at 8-17, Reed (No. 70-4).

341. 485 P.2d 529, 538-43 (Cal. 1971) (striking down statute barring women from being bartenders in licensed establishments, inconsistent with Equal Protection Clause (as well as title VII and state constitution)).

342. Douglas Conference Notes for Reed (Oct. 22, 1971), in Douglas Papers, supra note 192, Container 1525.

343. 404 U.S. 71 (1971). court).

344. 405 U.S. 970 (1971), affg mem:, 341 F. Supp. 217 (M.D. Ala. 1970) (three-judge

345. See generally MARY Frances BerRy, Why ERA FAILEd: Politics, WOMEN'S RIGHTS AND THE AMENDING PROCESS OF THE CONSTITUTION (1986); JANE J. MANSBRIDGE, Why We LOST THE ERA (1986); RIghtS OF PASSAGE: ThE PAST AND FUTURE OF THE ERA (Joan Hoff Wilson ed., 1986). 
Amendment litigation for sex equality continued apace. In 1973, the Supreme Court heard an appeal brought by the Southern Poverty Law Center in Fronteiro v.Richardson. ${ }^{346}$ The issue was whether the armed forces could deny female service personnel fringe benefits for their spouses absent a showing that the spouses were in fact "dependent" on them, a showing male service personnel did not have to make. Joseph Levin and Morris Dees' brief on appeal argued that the Court should apply strict scrutiny to the statutory sex discrimination; Ginsburg and Wulf filed an amicus brief making the same arguments for strict scrutiny they had made in Reed. ${ }^{347}$ Although Chief Justice Burger made an impassioned effort to dismiss this challenge as a "tempest in a teapot," the Brethren voted to reverse on the authority of Reed. . $^{348}$

Justice Brennan's initial draft opinion followed Reed but invited his colleagues to consider the question whether sex is a suspect classification, as the Frontieros and the ACLU were urging. ${ }^{349}$ Justices Douglas, White, and Marshall immediately urged him to do so, ${ }^{350}$ while the other Justices held off. Brennan circulated a new opinion which accepted the suspect classification argument along the lines suggested by the ACLU. The opinion argued that, given the nation's "long and unfortunate history of sex discrimination," the immutability of sex as a trait, and the wide normative agreement that sex is usually irrelevant to proper public policy, sex is enough like race to justify its being treated as a "suspect classification" triggering "strict judicial scrutiny." 351 Brennan's opinion only attracted the votes of four Justices, however. Chief Justice Burger and Justices Powell, Stewart, and Blackmun were reluctant to adopt the suspect classification approach so long as the ERA was pending, and they ended up concurring in the judgment, depriving Brennan of his needed fifth vote to make a Court. ${ }^{352}$

346. 411 U.S. 677 (1973).

347. Brief for the Appellants at 28-37, Frontiero (No. 71-1694); Brief of American Civil Liberties Union Amicus Curiae at 24-44, Frontiero (No. 71-1694). By 1971, it was wellestablished that equal protection guarantees of the Fourteenth Amendment were "reverseincorporated" into the Fifth Amendment's Due Process Clause.

348. Douglas Conference Notes for Frontiero, in Douglas Papers, supra note 192, Container 1577. Only the Chief Justice and Justice Rehnquist favored upholding the policy.

349. See William J. Brennan, Jr., Memorandum to the Conference, re No. 71-1694 Frontiero v. Laird (Feb. 14, 1973), in Brennan Papers, supra note 129, Box I: 299, Folder 11 (also including a draft of the opinion).

350. See id. (emended with a handwritten note from Justice Douglas saying that he preferred the new approach); Memorandum from Byron R. White to William J. Brennan, Jr. (Feb. 15, 1973), in Brennan Papers, supra note 129, Box I: 299, Folder 11.

351. Frontiero, 411 U.S. at $682-88$.

352. See id. at 697 (Powell, J., joined by Burger, C.J., and Blackmun, J., concurring in the judgment) (explicitly reserving the suspect classification question in light of the pending 
Nonetheless, Frontiero sent a powerful signal. Soon after losing the case, Solicitor General Erwin Griswold announced that the Equal Protection Clause "does not tolerate discrimination on the basis of sex." 353 As Professor Ginsburg read the case, "persons similarly situated, whether male or female, must be accorded even-handed treatment by the law." Legislative classifications, she concluded, "may not be premised on sex-role stereotypes or unalterable sex characteristics that bear no necessary relationship to an individual's need, ability or life situation." 354 Ginsburg's campaign, essentially, was to interpret the Equal Protection Clause to entrench a feminist understanding of the ERA, which was in the midst of fierce ratification battles in state legislatures that savvy observers felt was being lost. To accomplish this, she continued to bring cases to, or support cases before, the Supreme Court challenging sex discriminations that reflected archaic stereotypes. ${ }^{355}$

The Burger Court did not always agree with the ACLU. For example, the Justices upheld sex-based classifications when they appeared remedial, such as the Florida law allowing widows but not widowers a small property tax exemption, upheld in Kahn v. Shevin. ${ }^{356}$ (Recall that many feminists themselves, such as Kenyon and Murray, believed that genuinely remedial legislation ought to pass equal protection scrutiny.) As the ACLU advocated, the Court struck down classifications that appeared to hold women back because of archaic stereotypes, such as the law allowing a spouse to stop paying child support for daughters at an earlier age than for sons, invalidated in Stanton v. Stanton. ${ }^{357}$ In Taylor v. Lousiana ${ }^{358}$ the Court overruled

ERA); id. at 691 (Stewart, J., concurring in the judgment, without a statement of reasons). Justice Rehnquist dissented. Id. at 691.

353. Memorandum of Amicus Curiae United States at 8, Cohen v. Chesterfield County Sch. Bd., 411 U.S. 947 (1973) (No. 72-1129) and Cleveland Bd. of Educ. v. La Fleur, 414 U.S. 632 (1974) (No. 72-777).

354. Brief for Appellants at 11, Kahn v. Shevin, 416 U.S. 351 (1974) (No. 73-78) (Ginsburg et al. representing the appellant).

355. Interestingly, the plaintiffs she represented or befriended were Joseph as well as Sharron Frontiero, Mel Kahn, Stephen Charles Wiesenfeld, Will Webster, and William Herbert Orr - men harmed by sex discriminations. The strategy, controversial among feminists, was to show male judges that everybody - including people like them - was harmed by sex discrimination.

356. 416 U.S. 351 (1974) (Douglas, J.) (women are more likely to need the tax break); see also Califano v. Webster, 430 U.S. 313 (1977) (upholding gendered social security provision, which the Court read as advantaging female wage earners and their families, as a way of redressing society's longstanding disparate treatment of women); Schlesinger v. Ballard, 419 U.S. 498 (1975) (upholding a longer period for female officers to attain promotion for an "up or out" policy in the armed forces, because of greater difficulties women faced in compiling a record for promotion). In all three cases, the Court rejected the ACLU's arguments.

357. 421 U.S. 7 (1975); see also Weinberger v. Wiesenfeld, 420 U.S. 636 (1975) (Brennan, J.) (invalidating gendered social security provision, which the Court read as discrimi- 
Hoyt, on the ground that an opt-in system for women to serve on juries violates the Sixth Amendment and due process requirement that juries be cross-sections of the community.

The Women's Rights Project called on the Court to overrule Goesaert in Craig $v$. Boren. ${ }^{359}$ That case involved a state law barring the sale of two percent beer to eighteen-year-old males and twenty-one-year-old females, assertedly on the ground that the former were more likely to become inebriated and therefore a safety hazard than the latter. No longer making its pitch for strict scrutiny, the ACLU's amicus brief read the Supreme Court precedents for the stillstrong proposition that the judiciary should strike down statutes reflecting "traditional attitudes and prejudices about the expected behavior and roles of the two sexes in our society," for these are "part of the myriad signals and messages that daily underscore the notion of men as society's active members, women as men's quiescent companions, members of the 'other' second sex." 360 The Court was open to this statement of women's politics of recognition. Justice Brennan garnered six Justices to require that sex-based classifications "must serve important governmental objectives and must be substantially related to achievement of those objectives."361 Specifically, neither "administrative ... convenience" nor "overbroad and archaic generalizations" regarding men and women's different capacities or roles could justify sex-based classifications. ${ }^{362}$

Handed down in 1976, when it was likely the ERA would not be adopted, Craig seemed to satisfy liberal feminists' version of women's politics of recognition; the dissenting Justices certainly thought so. ${ }^{363}$ Notwithstanding the ambiguous level of scrutiny, the Craig formula-

nating against female wage earners), followed in Califano v. Westcott, 443 U.S. 76 (1979); Califano v. Goldfarb, 430 U.S. 199 (1977).

358. 419 U.S. 522 (1975), discussed in Section II.A.1.c.

359. 429 U.S. 190 (1976).

360. [ACLU] Brief Amicus Curiae at 22, Craig (No. 75-628) (citing SIMONE DE BEAUVOIR, SECOND SEX (1949)).

361. Craig, 429 U.S. at 197 (Brennan, J., for the Court, including Justices White, Marshall, Blackmun, Powell, and Stevens). Justice Stewart concurred only in the judgment, $i d$. at 214; Chief Justice Burger, $i d$. at 215, and Justice Rehnquist dissented, $i d$. at 217.

362. Id. at 198 (opinion of the Court) (quotation omitted).

363. See id. at 221 (Rehnquist, J., dissenting); Memorandum from Warren E. Burger (who also dissented) to William J. Brennan, Jr. (Nov. 15, 1976), in Brennan Papers, supra note 129, Box I: 411, Folder 2 (testily admonishing Brennan that he might have joined a Reed-like opinion, but that "you read into Reed $v$. Reed what is not there. Every gender distinction does not need the strict scrutiny test applicable to a criminal case."). Commentators agreed with the dissenters' assessment that "even if the ERA should fail to be ratified, before long the Court seems certain to reach the same conclusion under the equal protection clause." Kenneth L. Karst, The Supreme Court, 1976 Term - Foreword: Equal Citizenship Under the Fourteenth Amendment, 91 HARV. L. REV. 1, 54 (1977). 
tion - and its application in that case, where there was both a plausible safety justification and an arguable Twenty-First Amendment boost for state alcohol regulation - had teeth enough to clear out most sex discriminations from state codes. Even armed with Frontiero and Craig, however, liberal feminism's constitutionalized politics of recognition ran into a formidable doctrinal roadblock: the reluctance of the Justices to scrutinize classifications that strongly affected women but were not openly gendered. At the very same time that the Burger Court was subjecting sex-based classifications to heightened scrutiny, it was subjecting laws having disparate impact on race-based classes to ordinary scrutiny in Hackney, Rodriguez, and Washington v. Davis. There was no reason to expect the Justices to follow a different approach with regard to sex-based classes, with or without the ERA.

The most important issue for feminists was whether the state could discriminate on the basis of pregnancy. Representing women whose pregnancies were excluded from a state disability program in Geduldig v. Aiello, ${ }^{364}$ Wendy Webster Williams maintained that "the individual who receives a benefit or suffers a detriment because of a physical characteristic unique to one sex benefits or suffers because he or she belongs to one or the other sex" - which surely is sex discrimination, because men are treated differently. ${ }^{365}$ Moreover, men were treated more favorably than women, and for exactly the reasons rejected in Reed and Frontiero (and later in Craig): men were privileged and women were denigrated in the public and workplace sphere because of women's unique ability to bear children and the concomitant special responsibility for rearing them in the domestic sphere. ${ }^{366}$ Indeed, "[t]his last prejudice - that women are not serious and permanent members of the workforce and that lurking somewhere in each woman's life is a man fully able to support her - underlies and reinforces discrimination against women in all realms of their lives." ${ }^{.367}$ Williams' powerful presentation was supported by amicus briefs from the ACLU and the EEOC.

But the nine men on the Court were not persuaded. The discussion in conference revealed little comprehension of Williams' arguments. Most of the Justices agreed with their Chief's complaint that the preg-

364. 417 U.S. 484 (1974).

365. Brief for Appellees at 31, Geduldig (No. 73-640).

366. "Those who would make these unique physical differences a touchstone for unscrutinized differential treatment offer nothing other than the modern version of the historical rationales which were for so long the source of women's second class citizenship under the law." Id. at 36 .

367. Id. at $39-40$ (footnote numbers omitted); see id. at $42-45$ (relying on the similar interpretation of the ERA forwarded by Professor Thomas Emerson and his Yale law students in Barbara A. Brown et al., The Equal Rights Amendment: A Constitutional Basis for Equal Rights for Women, 80 YALE L.J. 871, 930 (1971)). 
nancy exclusion involves "a different kind of risk than illness covered by [the] Act. [P]rostate problem is covered - as is hysterectomy different from pregnancy." 368 Based upon this reasoning, the Court ruled that the pregnancy exclusion was not a sex-based classification ${ }^{369}$ and upheld the statutory scheme. During the same Term, the Court invalidated school board rules barring pregnant women from continuing their jobs as teachers, but the opinion by Justice Stewart (also the author of Geduldig) reasoned that the per se rule arbitrarily burdened the women's parenthood and family rights and so was unconstitutional under the Due Process Clause. ${ }^{370}$ In 1976, the Supreme Court followed Geduldig to interpret the sex discrimination bar in Title VII to be inapplicable to pregnancy-based discrimination. ${ }^{371}$ Wendy Williams again argued for the losing side - but it was her vision of sex discrimination that triumphed when she and Susan Deller Ross persuaded Congress to override the Court with the Pregnancy Discrimination Act of 1978 ("PDA"). ${ }^{372 ~ "[R] e a f f i r m[i n g] ~ t h a t ~ s e x ~ d i s-~}$ crimination includes discrimination based on pregnancy, and specifically defin[ing] standards which require that pregnant workers be treated the same as other employees on the basis of their ability or inability to work," ${ }^{773}$ the PDA provided a legal (even if not a constitutional) basis for liberal feminists' ongoing campaign to assure women conditions of employment that would allow them to have productive careers. ${ }^{374}$

368. Douglas Conference Notes for Geduldig (Mar. 29, 1974), in Douglas Papers, supra note 192, Container 1630 (O.T. 1973, Argued Cases, 73-640); see Brennan Conference Notes for Geduldig, in Brennan Papers, supra note 129, Box I: 311, Folder 4 (Burger argued that the "exclusion is not sex based but upon distinction between pregnancy and other ailments").

369. Geduldig, 417 U.S. at $496-97$ n.20.

370. Cleveland Bd. of Educ. v. LaFleur, 414 U.S. 632 (1974). The LaFleur conference presaged the Geduldig one, for Burger, Stewart, and Blackmun all went out of their way to emphasize that the "differentiation is not sex related," because it related only to pregnancy. Brennan Conference Notes for LaFleur, in Brennan Papers, supra note 129, Box I: 310 (No. 72-777) (quote is from Blackmun). Powell viewed the case in equal protection terms, but only required the board to show a rational basis. Id.

371. Gilbert v. Gen. Elec. Co., 429 U.S. 125 (1976).

372. 42 U.S.C. $\$ 2000 \mathrm{e}(\mathrm{k})(2000)$ (defining "because of sex" or "on the basis of sex" in Title VII to include pregnancy).

373. H. REP. NO. 95-948, at 3 (1978); see also SUZANNE UTTARO SAMUELS, FETAL RIGHTS, WOMEN'S RIGHTS: GENDER EQUALITY IN THE WORKPLACE (1995).

374. Chastened by Congress's immediate and angry override of Geduldig and Gilbert, the Supreme Court not only applied the PDA expansively to protect women's workplace rights, e.g., United Auto Workers v. Johnson Controls Inc., 499 U.S. 187, 211 (1991) (rejecting employer policy protecting potentially pregnant women against jobs posing hazards to fetuses), but also applied its preemptive force conservatively when confronted with state rules expanding women's workplace opportunities. California Fed. Sav. \& Loan Ass'n v. Guerra, 479 U.S. 272, 292 (1987) (holding that the PDA does not preempt a state law requiring employers to grant leaves for pregnant women). 
As the pregnancy cases reflect, feminists' politics of recognition insisted on heightened scrutiny of rules that had an inevitable impact on women. And, generally, the U.S. Supreme Court rejected their stance, just as it had rejected similar arguments made by people of color. The leading case was Personnel Administrator v. Feeney. ${ }^{375}$ Helen Feeney found it virtually impossible to advance in the civil service because of the operation of the state's strong preference for veterans. She challenged the preference for its significant adverse impact upon women's opportunities in a state where $98 \%$ of the veterans were men. Phyllis Segal's NOW amicus brief supporting her claim argued that the preference "inevitably discriminates deeply and pervasively against women as a result of a congeries of laws, regulations and practices which define as overwhelmingly male the class of individuals who qualify as veterans." 376 Invoking Washington $v$. Davis, the state responded that the classification itself (veterans) was benign and there was no evidence whatsoever of any intent to discriminate against women. ${ }^{377}$ With little internal dissent, the Supreme Court agreed. Justice Stewart's opinion for the Court was an important clarification of the burden of proving intent under Washington $v$. Davis: challengers to a state employment policy must show that the challenged policy was not only adopted in spite of its disparate impact on women (or racial minorities), but because of that impact. ${ }^{378}$

\section{The Politics of Remediation and the New Politics of Preservation, 1976-Present}

Traditionally, most opposition to equality for women was driven by open commitments to a natural law view in which sex and gender differences were viewed as profound and women's proper role was to bear and rear children and govern the domestic sphere. ${ }^{379}$ As women

375. 442 U.S. 256 (1979)

376. Brief of Amici Curiae National Organization for Women, NOW Legal Defense and Education Fund, Inc. et al. at 12-13, Feeney (No. 78-233).

377. Brief for Appellants at 30-57, Feeney (No. 78-233); accord 42 U.S.C. $\$ 2000 \mathrm{e}-11$ (veterans' preferences exempted from Title VII); Brief of Amicus Curiae United States, Feeney (No. 78-233) (agreeing with the state).

378. Feeney, 442 U.S. at 278-80. For an excellent analysis of Feeney as a different "intent" standard than that in Washington v. Davis and Arlington Heights, see Sheila Foster, Intent and Incoherence, 72 TUL. L. REV. 1065 (1998).

379. Examples of such natural law discourse include Goesaert v. Cleary, 335 U.S. 464 (1948) (allowing women to tend bar only if employed by their fathers or husbands); Muller v. Oregon, 208 U.S. 412 (1908) (upholding maximum hours law to protect only women); Bradwell v. Illinois, 83 U.S. 130 (1873) (Bradley, J., concurring in the judgment) (excluding women from the practice of law); PHYLlis SCHLAfLy, THE POWER OF THE POSITIVE WOMAN 54, 159-63 (1977) (normative book by the leading opponent of the ERA); Siegel, 
increasingly objected to their subordinate status and moved public opinion toward the idea that sex is a tolerable variation as far as most public policies were concerned, pragmatic arguments came to the fore. Although natural law continued to be the basis for supporting traditional gender roles and separate spheres, preservationist rhetoric gradually shifted to include or emphasize the bad consequences of "radical" change, including harms to the privacy of the marital relationship and the harmony of the family, the psychic costs to women as well as men if traditional mores were upset, and the possibilities of violence and disorder. ${ }^{380}$ As in the race cases, the shift in rhetoric was accelerated by the Supreme Court's sex discrimination jurisprudence. Because traditionalist arguments for the status quo came perilously close to the kinds of "archaic" notions about sex differences that were automatically lethal in cases like Craig and Frontiero, these precedents pressed preservationists strongly toward pragmatic rather than natural law arguments, at least in public. Like the politics of racial preservation, the politics of sex and gender role preservation in the 1970s and 1980s was dominated by this kind of cost-benefit moderation, with at least one important exception. Pragmatists as well as traditionalists paid attention to women's "real differences" from men, particularly those related to pregnancy and women's responsibilities to the unborn as well as the children they (still) reared. ${ }^{381}$ Indeed, feminists themselves split on the issue. A new generation of difference feminists urged the necessity of state rules empowering and compensating women for their traditionally undervalued caretaking roles. ${ }^{382}$

Like the liberal feminists they were opposing, both pragmatic and natural law preservationists invoked the Constitution. They maintained that sex-neutral and abortion-protective rules imposed by judges in Washington, D.C. were at war with (1) the values of local-

She the People, supra note 237 (discussing arguments against female suffrage and ratification of the Nineteenth Amendment).

380. See generally Reva B. Siegel, The Modernization of Marital Status Law: Adjudicating Wives' Rights to Earnings, 1860-1930, 82 GEO. L.J. 2127 (1994); Reva B. Siegel, "The Rule of Love": Wife Beating as Prerogative and Privacy, 105 YALE L.J. 2117, 2119-20 (1996) (arguing in two different contexts that when traditional male privileges came under fire, their justifications were "modernized" and thereby strengthened).

381. Thus, women (the supposed beneficiaries of the politics of recognition) have been well-represented in the pro-life and anti-ERA politics of preservation. Women opposing the liberal feminist agenda hold different views than the liberals regarding gender roles, sexuality, and parenting. Generally, they view women's greatest fulfillment in their roles as wives and mothers. See LUKER, supra note 290, at 158-91 (pro-life women); MANSBRIDGE, supra note 345, at 98-117 (1986) (anti-ERA women).

382. Although difference feminism is typically set "against" liberal feminism, that is simplistic. Both liberals like Wendy Williams and Ruth Ginsburg and difference feminists like Chris Littleton agreed with Pauli Murray and Celia Kenyon that neither the ERA nor the equal protection clause should be construed to invalidate legislation genuinely remedial to women's traditional disadvantages, especially in the workplace. 
ism, where the family and the state were the primary situs for rules relating to gender-normative roles in bearing and raising children, without interference from the national government; (2) the constitutional separation of powers, whereby the popularly elected legislature is both the most legitimate and the most institutionally competent state organ to handle complex, delicate moral and family issues; and (3) fundamental liberties, particularly the rights of fetuses and parents. These arguments were prominent in the campaign to defeat the ERA. Phyllis Schlafly and other opponents argued that the ERA was a bad idea because it would undermine the family and deprive states of their ability to legislate morality (including sexual abstinence and compulsory heterosexuality), would empower unaccountable federal judges to impose their own elite views on an unconsenting populace, and would deprive wives and parents of fundamental rights needed for the preservation of families. ${ }^{383}$

The arguments that sunk the ERA also instructed the Supreme Court regarding the extent to which it should apply the Equal Protection Clause to liberate women from archaic stereotypes. ${ }^{384}$ Among Mrs. Schlafly's most popular charges against the ERA were that it would empower the Supreme Court to subject women to the draft and military service, to invalidate gendered laws protecting women, and to require states to recognize same-sex marriages and other "homosexual rights." 385 Americans supported sex segregation in military service, many special protections for women, and marriage limited to different-sex couples. While the ERA lingered, the Supreme Court reaffirmed all of the foregoing sex discriminations, substantially following the constitutional logic of Mrs. Schlafly and her allies. Between 1972 and 1975, the Court brushed aside sex discrimination (and other) arguments for same-sex marriage and sodomy law nullification without even asking for briefs on the merits. ${ }^{386}$ The Court addressed

383. See Mansbridge, supra note 345; Donald G. Mathews \& Jane Sherron De HART, SEX, Gender, AND THE Politics of THE ERA: A STATE AND THE NATION (1990) (case study of the ERA's defeat in North Carolina); id. at 35-53 (arguments against ERA by Senator Ervin [D-N.C.] during its debate in Senate, 1971-72).

384. Recall that four concurring Justices declined to join Justice Brennan's opinion in Frontiero because these arguments were being seriously debated in connection with the ERA. See supra note 352.

385. See Phylis Schlafly, What's Wrong with "Equal Rights" for Women?, 5 PHYLlis SCHLAFLY REP. NO. 7, Feb. 1972, reprinted in WOMEN'S RIGHTS IN THE UNITED STATES: A DOCUMENTARY HISTORY 291 (Winston E. Langley \& Vivian C. Fox eds., 1994) (women would be subject to the draft and would lose custody of their children); Phyllis Schlafly, Memo on the Equal Rights Amendment 2000, at http://www.eagleforum.org/ era/ERA99.shtml (last visited Aug. 20, 2002) (federally funded abortions and rights for "homosexuals," including marriage).

386. See Doe v. Commonwealth's Attorney for Richmond, 425 U.S. 901 (1976) (summarily affirming state consensual sodomy law); Baker v. Nelson, 409 U.S. 810 (1972) (dismissing 
the other two issues in 1981, just before the period for ERA ratification expired for good (1982).

As Feeney and Frontiero illustrated, the United States armed forces operated under a cornucopia of sex-discriminatory rules, the centerpiece of which was the exclusion of women from combat roles. Women's marginal role in the military was, from the perspective of most feminists, a textbook example of the way in which sexist public law reinforced women's status as second-class citizens. ${ }^{387}$ Traditionalists viewed women's exclusion as necessary, lest the military be feminized and weakened. ${ }^{388}$ Such a justification was insufficient under Craig or even Reed. The modernized (pragmatic) justification for exclusions was that unit cohesion would break down if women joined in combat. ${ }^{389}$ For this and other reasons, the 1980 reactivation of the draft required only men to register. A three-judge court ruled that the sex discrimination violated the Craig standard. Although the ACLU was joined on appeal by NOW, the League of Women Voters, and a number of other feminist organizations, and a generation of the nation's finest constitutional lawyers (like Wendy Williams and Larry Tribe) defended the lower court judgment, their arguments fell on deaf (or deferential) judicial ears. Justice Rehnquist's opinion in Rostker $v$. Goldberg $^{390}$ emphasized that the Constitution commits military policy to the political branches, that the judiciary has very little competence to evaluate their policy choices, and that Congress had in this case engaged in careful factfinding and deliberation to which the Court must defer. Moreover, "the decision to exempt women from registration was not the " "accidental by-product of a traditional way of thinking about females." " "391 Instead, the decision was a corollary of the proposition that women were barred from combat roles, a bar not challenged by the plaintiffs. ${ }^{32}$ Writing for three dissenters, Justice

appeal of rejected challenge to state bar to same-sex marriages); see also supra Section I.C.2 (discussing Baker and Doe).

387. Kenneth L. Karst, The Pursuit of Manhood and the Desegregation of the Armed Forces, 38 UCLA L. REV. 499 (1991); see also Lori Kornblum, Women Warriors in a Men's World: The Combat Exclusion, 2 L. \& INEQUALITY 351 (1984); Wendy Webster Williams, The Equality Crisis: Some Reflections on Culture, Courts, and Feminism, 7 WOMEN's RIGHTS L. REP. 175, 182-85 (1982).

388. See BRIAN MitChell, WeAK Link: the FEMINIZATION OF tHE AMERICAN MiLITARY (1989).

389. See generally FEMALE SOLDIERS - COMBATANTS OR NONCOMBATANTS? HISTORICAL AND CONTEMPORARY PERSPECTIVES (Nancy Loring Goldman ed., 1982) [hereinafter FEMALE SOLDIERS]. Note especially Mady Weschler Segal, The Argument for Female Combatants, in FEMALE SOLDIERS, supra.

390. Rostker v. Goldberg, 453 U.S. 57, 64-74 (1981).

391. Id. at 74 (quoting Califano v. Webster, 430 U.S. 313, 320 (1977), in turn quoting Califano v. Goldfarb, 430 U.S. 199, 223 (1977)). 
Marshall found more at stake in the challenge because women were being excluded from "a fundamental civic obligation." 393

The Court was also tolerant of sex-based classifications protecting women against male predation. Although states in the 1970 s redrafted their penal codes to be largely sex-neutral, California continued to make it a felony for a male (of any age) to have sexual intercourse with a female under the age of eighteen. In Michael $M$. v. Superior Court, ${ }^{394}$ plaintiffs and their amici challenged the statute as a classic sex discrimination based upon traditional gender stereotypes, where the vulnerable girl needs to be protected against predatory boys and men, but boys can take care of themselves. ${ }^{395}$ California and the United States, which entered the case as an amicus, defended the statute as appropriately focusing regulatory attention on the main problem, the need to protect girls against predation and unwanted pregnancies. ${ }^{396}$ The statutory rape law was a prophylactic measure to protect minor women who were in fact vulnerable to sexual assault. Its sex discrimination was permissible, because women rarely assaulted boys; it was necessary to the operation of this policy, because girls would be reluctant to report violations if they themselves could be prosecuted. Five Justices accepted this justification. ${ }^{397}$ Dissenting Justices and feminist critics of the decision disputed both elements of the Court's logic: the historical policy of the gendered statute was rooted in archaic stereotypes of vulnerable girls and predatory boys, and a humane anti-predation policy that recognizes girls' as well as boys' sexual agency can criminalize sex between adults and underage persons of either sex. ${ }^{398}$

Although the Supreme Court proved receptive to preservationist arguments in the areas of greatest social anxiety about sex equality -

392. Because the goal of registration was to prepare for combat mobilization, it was a reasonable decision to register only those who could engage in combat, men. $I d$. at 76-83.

393. Id at at 86 (Marshall, J., dissenting). Marshall demonstrated that the Court attributed a more rational policy to Congress than could be supported from the record and that the experts to whom greatest deference was owed (the Joint Chiefs of Staff and the President) had supported the registration of women. Id. at 88-113.

394. 450 U.S. 464 (1981).

395. See Brief of Amici Curiae ACLU and the ACLU of Northern California, Michael M. (No. 79-1344).

396. Brief of Amicus Curiae United States at 13-24, Michael M. (No. 79-1344).

397. See Michael M., 450 U.S. at $470-76$ (Rehnquist, J., for a plurality); id. at $478-80$ (Stewart, J., concurring); $i d$. at 481-87 (Blackmun, J., concurring in the judgment).

398. See id. at 493-95 (Brennan, J., dissenting); Kristin Bumiller, Rape as a Legal Symbol: An Essay on Sexual Violence and Racism, 42 U. MIAMI L. REV. 75 (1987); Frances Olsen, Statutory Rape: A Feminist Critique of Rights Analysis, 63 TEXAs L. REV. 387 (1987); Williams, supra note 387, at 181-82; see also Catharine A. MacKinnon, Reflections on Sex Equality Under Law, 100 YALE L.J. 1281, 1305 (1991) (criticizing both majority and dissenting Justices). 
same-sex marriage, women in combat, and statutory rape - it did not retreat from Craig's baseline, even after the Court shifted toward the right after President Reagan's election in 1980. Indeed, Reagan's first Supreme Court appointee was Sandra Day O'Connor, the first woman to serve on the Court. ${ }^{399}$ In one of her earliest major opinions for the Court, Mississippi University for Women v. Hogan, ${ }^{400}$ Justice O'Connor struck down a state law allowing only women to enroll at the state nursing college. When a law adopts a sex-based classification, the state has a "burden of showing an "exceedingly persuasive justification' for the classification," a burden that cannot be met by post-hoc rationalizations by counsel or policies that ultimately rest upon gender stereotypes. ${ }^{401}$ With Craig, Hogan remains the leading statement of the Court's approach to statutory sex discriminations, and the Rehnquist Court - often over the objection of its Chief - has been just as vigorous as the Burger Court was in carrying out the liberal feminist politics of recognition under cover of the Equal Protection Clause. No longer can women be peremptorily struck from juries without explanation $^{402}$ or excluded from state paramilitary colleges, ${ }^{403}$ for prominent examples. In both cases, Justice O'Connor was in the majority, and the opinion for the Court quoted and applied Hogan. ${ }^{404}$

The foregoing sex discrimination cases reflect the Court's stance as the twentieth century came to a close: consistent with the feminist politics of recognition (and public opinion), most of the Justices have insisted on formal equality and respect for women's co-equal role in public as well as private life. ${ }^{405}$ On the other hand, and probably consistent with public opinion, the Justices backed away when women's equality was strongly inconsistent with third-party rights, the legitimacy and comparative competence of the judiciary (vis à vis the political branches), and the Constitution's preference for local decisionmaking as to matters of family life and public safety.

399. Although a reliable conservative on issues of federalism, separation of powers, and the individual rights of racial and sexual minorities, Justice O'Connor also proved attentive, in a way her Reagan Brethren were not, to feminist voices. E.g., Judith Olans Brown et al., The Rugged Feminism of Sandra Day O'Connor, 32 IND. L. REV. 1219 (1999); Sandra Day O'Connor, Portia's Progress, 66 NYU L. REv. 1546, 1553 (1991).

400. 458 U.S. 718 (1982), also discussed in Section II.C.3 infra. Because the decision was 5-4, the replacement of Justice Stewart (a conservative in sex discrimination cases) with Justice O'Connor very probably changed the outcome of the case.

401. Id. at 724 .

402. J.E.B. v. Alabama ex rel. T.B., 511 U.S. 127 (1994).

403. United States v. Virginia, 518 U.S. 515 (1996).

404. Id. at 523-24; J.E.B., 511 U.S. at 136.

405. See Rosen, THE WORLD SPLIT OPEN, supra note 299, at 338 (opinion polls have found large majorities of Americans supportive of a "strong women's movement to push for changes that benefit women"). 
Although the foregoing constitutional clashes between women's politics of recognition and traditionalists' politics of preservation were important and meaningful, the most intense post-1976 clashes involved the unique issue of abortion and issues of remediation. Abortion has been an intense question because it is so important for each group and their points of view are incommensurable: feminists understand choice as essential to their equal citizenship, while traditionalists understand life to be at stake. As with the civil rights movement, the other contentious issues relate to women's politics of remediation. The women's movement has sought and obtained statutes and administrative rules protecting against private workplace discrimination and sexual harassment; requiring integration of public accommodations; insisting that schools not only protect girls against sexual harassment, but also devote equal resources to girls' athletic as well as educational programs; modernizing rape laws and criminalizing hate speech; and providing tort causes of action for gender-based violence. Remedial measures such as these are costly and may cross fuzzy constitutional lines relating to federalism, separation of powers, and individual rights of free speech and association. Even as they were being routed as to matters of women's equal rights to serve on juries and attend paramilitary colleges, preservationists have made successful court challenges to feminist remedial measures suppressing misogynistic pornography, regulating pro-life protests and persuasive activities outside abortion clinics, and (most controversially) creating a federal cause of action for gender-based violence.

a. The Post-Roe Abortion Cases. Pro-life traditionalists mobilized as a normative social movement seeking to preserve not only human life, but also a traditionalist ethic of family values and women's domestic role. ${ }^{406}$ They maintained that Roe $v$. Wade was worse than the ERA because it took the most moral of issues away from family and state decisionmaking, represented the most arrogant example of judicial legislation, and blatantly ignored the fundamental right to life of the most vulnerable party to the matter, the unborn human child..$^{407}$ Through organs such as the National Right to Life Committee (1973), the movement sought to amend the Constitution to overrule Roe and, failing that, to adopt new state laws regulating abortion in a variety of ways. These laws, in turn, were challenged by pro-choice groups and defended by state attorneys general and their pro-life amici. Three kinds of abortion-regulatory laws illustrate how this ongoing culture

406. See Dallas A. Blanchard, The Anti-Abortion Movement and the Rise OF THE RELIGIOUS RIGHT: FroM POLITE TO FIREY PROTEST 22-36 (1994) (providing an institutional history of the pro-life movement); $i d$. at 44-46 (providing essential ideology of pro-lifers).

407. See id. at 37-50; Luker, supra note 290. 
clash played itself out in constitutional law: parental and spousal notification and consent requirements, bars to public funding or assistance for abortions, and informed consent rules seeking to persuade women to think twice before they chose abortions.

In Planned Parenthood v. Danforth, ${ }^{408}$ the first major post-Roe case, Missouri Attorney General John Danforth pressed a pro-life constitutional understanding in support of Missouri's law which required a minor to obtain her parents' consent and a wife to obtain her husband's consent before an abortion could be performed. He was supported by an amicus brief from the United States Catholic Conference. ${ }^{409}$ Both argued that "the [constitutional] rights of parents to the exercise of their authority is considered fundamental and only a compelling interest by the state can overcome it." ${ }^{410}$ Similarly, both invoked the right to marry cases, including Griswold, for the proposition that family decisions, including those relating to pregnancy, are joint decisions in which the husband has a legally protected interest, just as his wife does. ${ }^{411}$ These arguments had an audience on the Court: Justices White, Rehnquist, and Stevens were persuaded by the arguments for parental consent; White and Rehnquist went with spousal consent as well. ${ }^{412}$ But a majority of the Court insisted on the individualistic framework suggested by Roe and supported by Planned Parenthood's detailed argument that, in practice, the state's consent rules would give parents and husbands vetoes over a decision that was ultimately personal to the mother. ${ }^{413}$

The foregoing pro-life constitutional arguments were pressed more ardently in Bellotti v. Baird ${ }^{414}$ which evaluated a Massachusetts law requiring minors to notify their parents and obtain their consent before they could obtain abortions, with a judicial proceeding available if

408. 428 U.S. 52 (1976).

409. The National Catholic Bishops' Conference had in 1967 established a Committee on Family Life, which was the main speaker for the pro-life viewpoint before Roe. The Committee was the precursor to the National Right to Life Committee, formed in 1973. Blanchard, supra note 406, at 50-53.

410. Brief of Amicus Curiae the United States Catholic Conference at 24, Planned Parenthood v. Danforth, 428 U.S. 52 (1976) (No. 74-1151); see Brief for Appellees at 42-44, Danforth (No. 74-1151).

411. Brief of Amicus Curiae the United States Catholic Conference at 32-39, Danforth (No. 74-1151); Brief for Appellees at 38, Danforth (No. 74-1151).

412. See Danforth, 428 U.S. at 94 (Stevens, J., dissenting); Brennan Conference Notes for Danforth (Nos. 74-1151, 74-1419), in Brennan Papers, supra note 129, Box I: 368, Folder 6 .

413. Danforth, 428 U.S. at $68-72$ (parental consent), id. at $72-75$ (spousal consent); Brief for Appellants and Cross-Appellees Planned Parenthood of Central Missouri, et al., at 72-90, Danforth (Nos. 74-1151, 74-1419) (spousal consent), id. at 90-105 (parental consent).

414. 443 U.S. 627 (1979). 
either parent refused and the minor felt it was in her best interests. Several amici argued that the constitutional protection for family integrity not only justified the parental consent requirement, but also barred the state from overriding the parents' decision with the judicial bypass. ${ }^{415}$ Writing for a plurality of the Court, Justice Powell accepted the traditionalists' point that the state has much more leeway in regulating the sexual choices of minors because of "the peculiar vulnerability of children; their inability to make critical decisions in an informed, mature manner; and the importance of the parental role in child rearing." ${ }^{416}$ Powell also adopted the amici's localist stance that moral instruction and choice for minors lay first within the family, and "beyond the competence of impersonal political institutions." 417 On the other hand, he agreed with the challengers' claim that the statute was overbroad: it required notification even when there was no chance of productive dialogue and therefore was an "undue burden" on the minor's right to choose an abortion. ${ }^{418}$ In dictum, Justice Powell suggested that states could require both parents to consent to the procedure, so long as there was a judicial bypass available to the minor in lieu of parental dialogue. ${ }^{419}$ Because Powell spoke for four Justices and a fifth (White) believed the Massachusetts law was valid, Bellotti indicated that there was a Court that would uphold subsequent parental consent and notification laws - as indeed there was in subsequent cases, notwithstanding mounting evidence that even notification-with-bypass requirements imposed traumatic burdens on minor women. ${ }^{420}$

415. See Brief of Amici Curiae Catholic League for Religious and Civil Rights, et. al at 6-32, Bellotti v. Baird, 443 U.S. 627 (1979) (No. 78-329).

416. Bellotti, 443 U.S. at 634 (Powell, J., for a plurality joined by Burger, C.J., and Stewart \& Rehnquist, JJ.); id. at 637-39 (discussion relying on Pierce v. Society of Sisters, 268 U.S. 510, 535 (1925) and other cases emphasized by the state and its amici).

417. Id. at 638. "Thus, 'it is cardinal with us that the custody, care and nurture of the child reside first in the parents, whose primary function and freedom include prep for obligations the state can neither supply nor hinder." Id. (quoting Prince v. Massachusetts, 321 U.S. $158,166(1944))$.

418. Id. at 646-50.

419. Id. at 649 .

420. To trace the development of the doctrine, see H.L. v. Matheson, 450 U.S. 398 (1981) (upholding parental notification-whenever-possible requirement); Planned Parenthood Ass'n v. Ashcroft, 462 U.S. 476 (1983) (upholding parental-consent law, with judicial bypass as suggested in Bellotti); Hodgson v. Minnesota, 497 U.S. 417 (1990) (upholding a two-parent notification, with bypass, law against strong social science evidence and lower court findings of fact that notification did not contribute to healthy dialogue about the important moral choice and instead contributed to trauma for the minors); Planned Parenthood v. Casey, 505 U.S. 833 (1992) (joint opinion, delivering the judgment of the Court) (upholding one-parent consent requirement, with judicial bypass, but striking down spousal notification requirement). For an analysis of the social science evidence that the parentalconsent and notification requirements burden women and do not contribute to family com- 
The Supreme Court was also responsive to the arguments of pragmatic preservationists that even if choosing an abortion was a tolerable moral choice, such that the state could ordinarily not make it a crime, abortion was not a benign or good moral choice, such that the state must support or "promote" it. In Maher v. Roe, ${ }^{421}$ the Court ruled that it is not unconstitutional for state medicaid programs to exclude abortions even if they fund childbirths. Justice Powell's opinion for the Court interpreted Roe-Danforth-Bellotti as protecting women against "unduly burdensome interference with her freedom to decide whether to terminate her pregnancy" - a freedom from state "compulsion" that did not entitle women to have their abortions paid for by the state. ${ }^{422}$ "There is a basic difference between direct state interference with a protected activity and state encouragement of an alternative activity consonant with legislative policy." $" 423$ The state has wide latitude not to "promote abortion" by funding it, and Powell's opinion concluded with a statement that this is precisely the sort of policy issue best left to the democratically elected legislators. ${ }^{424}$

Maher encouraged pro-life activists to press for laws not only requiring that abortions be performed only after doctors obtain the written consent of their patients (a requirement upheld in Danforth), ${ }^{425}$ but also that the consent be "informed" by pro-life information the doctors were required to provide. Akron, Ohio, for example, required doctors to inform their patients about "the anatomical and physiological characteristics of the particular unborn child," many possible complications of abortion, and the "fact" that "the unborn child is a human life from the moment of conception." This was a powerful bit of lobbying by the state, and an intrusion into the doctor-patient relationship, but one that was defended by the Reagan Administration, which argued that Roe was not strongly implicated in regulations that did not "unduly burden" the woman's ability to obtain an abortion

munication, see William N. ESKridge, JR. \& NAN D. Hunter, SEXUALiTy, Gender, AND THE LAW 190-202 (1997) [hereinafter ESKRIDGE \& HUNTER, SEXUALITY].

421. 432 U.S. 464 (1977). See also Maher's companion cases, Beal v. Doe, 432 U.S. 438 (1977) (interpreting Social Security Act to allow states to participate in medicaid program without funding abortions), and Poelker v. Doe, 432 U.S. 519 (1977) (per curiam) (municipal hospital providing childbirth services was not constitutionally required to provide abortion services). The Court followed and applied Maher to uphold a federal bar to spending federal monies on abortions in Harris v. McRae, 448 U.S. 297 (1980).

422. Maher, 432 U.S. at 473-74 (citing Whalen v. Roe, 429 U.S. 589, 599-600 (1977)).

423. Id at 475 . Powell contrasted a law barring schools from teaching German, invalidated in Meyer v. Nebraska, 262 U.S. 390 (1923), with a policy of teaching Latin as the only foreign language in the public schools, which the Court would uphold. Maher, 432 U.S. at 476-77.

424. Id. at 479-80; see id. at 481-82 (Burger, C.J., concurring) (same).

425. Planned Parenthood v. Danforth, 428 U.S. 52, 67, 85 (1976). 
and that the Court should "accord heavy deference to the legislative judgment" in determining whether this and other requirements constituted an "undue burden" on the pregnant patient. ${ }^{426}$ The Inc. Fund, in an amicus brief, reminded the Court that deference to legislative judgments had been the last line of segregationist constitutionalism and that Brown and other race cases had decisively rejected this kind of argument. ${ }^{427}$ In any event, the required disclosures loaded up the informed consent process too much for Justice Powell, who wrote for the Court in striking down this ordinance in Akron v. Akron Center for Reproductive Health. ${ }^{428}$ "By insisting upon recitation of a lengthy and inflexible list of information, Akron unreasonably has placed 'obstacles in the path of the doctor upon whom [the woman is] entitled to rely for advice in connection with her decision." " 429

The Court followed Akron in Thornburgh v. American College of Obstetricians and Gynecologists, ${ }^{430}$ which struck down a similarly loaded informed consent statute. Justice Blackmun's opinion for the Court was more forceful than that in Akron, however. "The States are not free, under the guise of protecting maternal health or potential life," state interests recognized as valid in Roe, "to intimidate women into continuing pregnancies" or "to deter a woman from making a decision that, with her physician, is hers to make." ${ }^{431}$ Thornburgh is significant, for it represented an advance for the politics of preservation's campaign to overrule Roe. Solicitor General Charles Fried filed an amicus brief urging the Court to abandon Roe's "rigid" trimester framework and to apply Maher's "undue burden" approach to evaluate the informed consent provisions ${ }^{432}$ - and his brief drew general

426. Brief of Amicus Curiae the United States at 6-7, Akron v. Akron Ctr. for Reproductive Health, 462 U.S. 416 (1983) (No. 81-746) (undue burden as the constitutional standard); id. at 8-10 (deference to legislators); $c f . i d$. at 5 n.1 (reserving the question whether the government believed Roe was correctly decided).

427. Brief of Amicus Curiae NAACP Legal Defense and Educational Fund, Inc. at 5-12, Akron (No. 81-746).

428. 462 U.S. $416,442-49$ (1983).

429. Id. at 445 (quoting Whalen, 429 U.S. at 604 n.33). Powell rejected the argument, pressed in dissent by Justice O'Connor, that the unconstitutional advice could be severed from other information that Akron properly required doctors to make available. $I d$. at 445 46 n.37.

430. 476 U.S. 747 (1986).

431. Id. at 759 .

432. See Brief of Amicus Curiae the United States at 17-18, Thornburgh v. American College of Obstetricians and Gynecologists, 476 U.S. 747 (1986) (No. 84-495) (urging the Court to abandon the Roe framework for analysis). 
support from four Justices, including Chief Justice Burger (who had joined Roe and subsequent majority opinions). ${ }^{433}$

After President Reagan appointed Antonin Scalia and Anthony Kennedy to the Court, only three of the seven Roe Justices remained on the Court, and there was every reason to believe that Roe would be narrowed or overruled. ${ }^{434}$ The life/choice culture clash broke open in Webster v. Reproductive Health Services. ${ }^{435}$ Missouri required doctors to perform viability tests near the end of the second trimester, a requirement foreclosed by Roe as applied in Akron. ${ }^{436}$ The state asked the Court to reconsider and overrule Roe $v$. Wade - a petition joined by dozens of right-to-life amici and the Reagan Administration. ${ }^{437}$ The Solicitor General argued that Roe created a fundamental right that was not supported by constitutional text, intent, or tradition; denigrated the state's interest in potential human life without any legal or moral basis; created an arbitrary trimester framework for implementing its flawed premises; and, most important, engaged in this activism in the teeth of popular demands for regulation. ${ }^{438}$ "At the heart of the abortion controversy lies a divisive conflict between a woman's interest in procreative choice and the State's interest in protecting the life of an unborn child and promoting respect for life generally. This is not the kind of conflict that is amenable to judicial resolution." 439 Indeed, judicial activism tangibly interfered with the proper operation of the democratic process; by constitutionalizing the key issues, Roe deprived legislators of the room to bargain and moderate the views of the various groups. ${ }^{440}$

433. Thornburgh, 476 U.S. at $782-85$ (Burger, C.J., dissenting); id. at 785-814 (White, J., joined by Rehnquist, J., dissenting); id. at 814 (O'Connor, J., joined by Rehnquist, J., dissenting).

434. See Walter Dellinger \& Gene Sperling, Abortion and the Supreme Court: The Retreat from Roe v. Wade, 138 U. PA. L. REV. 83 (1989).

435. 492 U.S. 490 (1989).

436. Akron, 462 U.S. at 434-38.

437. Among the religious groups filing briefs to overrule Roe were the United States Catholic Conference; the Southern Baptist Convention; the National Association of Evangelicals; the Missouri Synod of the Lutheran Church; the Holy Orthodox Church. Other amici represented Feminists for Life of America; the National Association of Pro-Life Nurses; Women Exploited by Abortion; the Family Research Council; Right to Life Advocates.

438. Brief for Amicus Curiae the United States at 11-20, Webster v. Reprod. Health Servs., 492 U.S. 490 (1989) (No. 88-605).

439. Id. at 20 .

440. Id. at 20-24; see also MARY ANN GLENDON, ABORTION AND DivORCE IN WESTERN LAW: AMERICAN FAILURES, EuROPEAN CHALlEnges (1987) (most western countries have resolved these issues through legislation), discussed in Brief of Amicus $\mathrm{Cu}-$ riae the United States at 23-24, Webster (No. 88-605). 
We do not know exactly how the Justices received these arguments in conference, but ultimately the Court met the Reagan Administration more than halfway. Chief Justice Rehnquist's opinion for three Justices did not question Roe's holding that a woman's choice is a "liberty interest protected by the Due Process Clause" but seemed open to the Solicitor General's view that the liberty interest did not require strict scrutiny; following the administration, his opinion abandoned Roe's trimester framework, as it had been applied as recently as Thornburgh. ${ }^{441}$ Declining to follow the administration's lead so completely, Justice O'Connor concurred only in the result, applying Maher's "undue burden" analysis. ${ }^{442}$ Justice Scalia also concurred only in the result. In his own distinctive language, he advanced the Solicitor General's position: Roe should be completely overruled. ${ }^{443}$

Roe seemed doomed after two more of its majority (Brennan and Marshall) left the Court and were replaced by Justices Souter and Thomas. Both the Solicitor General and the Commonwealth of Pennsylvania, joined by dozens of amici, again urged the Court to overrule Roe in Planned Parenthood v. Casey. ${ }^{444}$ Planned Parenthood suggested that the state law could not be sustained without overruling Roe but urged that the Court not do so. ${ }^{445}$ A large majority of Americans believed that women do have liberty interests in their decisions whether to choose to abort an unplanned pregnancy, ${ }^{446}$ and a great deal of American law and family practice had evolved in reliance on the rights recognized for a generation under Roe. The conservative Court faced a dilemma, which its centrists - Justices O'Connor, Kennedy, and Souter - resolved in a Solomonic way. Their joint opinion, which also delivered the judgment of a fractured Court, reaffirmed Roe's holding that the Due Process Clause guarantees a "woman's [fundamental] right to terminate her pregnancy before

441. Webster, 492 U.S. at 517 (Rehnquist, C.J., joined by White \& Kennedy, JJ.).

442. Id. at 530 (O'Connor, J., concurring in the judgment). Contra Brief of Amicus Curiae the United States at 22, Webster (No. 88-605) (rejecting the "undue burden" approach as unmoored in the Constitution and therefore arbitrary); id. at $22 \mathrm{n} .16$ (if the Court adopts an undue burden approach, the focus should be the "burden on procreational choice" and not the "burden on abortion").

443. Webster, 492 U.S. at 537 (Scalia, J., concurring in the judgment).

444. 505 U.S. 833 (1992). For demands that the Court overrule Roe, see, for example, Brief of Amicus Curiae the United States Supporting Respondents at 8-9, Casey (No. 91744); Brief for Respondents at 104-17, Casey (No. 91-744).

445. See Brief for Petitioners and Cross-Respondents at 17-34, Casey (No. 91-744).

446. See, e.g., Elizabeth Adell Cook et Al., Between Two Absolutes: Public OPINION AND THE POLITICS OF ABORTION (1992); Noemie Emery, The Women Who Really Want This President, THE SPECTATOR, Jan. 31, 1998, at 12 (61\% of Americans support some right to abortion). 
viability," while at the same time jettisoning the trimester framework, "which we do not consider to be part of the essential holding of Roe." $" 47$

In place of the prior framework, the three controlling Justices ruled that the appropriate test should be whether a state regulation imposes an "undue burden" on the woman, namely, that it "has the purpose or effect of placing a substantial obstacle in the path of a woman seeking abortion of a nonviable fetus." ${ }^{448}$ The joint opinion applied this test to allow the state requirements of parental consent (with the Bellotti bypass) and the woman's written consent after she had been given state-required information about the fetus and the consequences of the abortion. ${ }^{449}$ Although the latter holding essentially overruled Akron and Thornburgh, the joint opinion justified it in feminist terms that tied women's politics of recognition to the state's right to promote its own conception of the good. ${ }^{450}$ Reaffirming Danforth, the joint opinion rejected the spousal notification requirement in terms of women's politics of recognition. No longer could the Court presume, as it wrongly did in Hoyt and Bradwell, that a woman's place is in the home, under the thumb of her husband and consigned to bearing and raising children. The spousal notification provision "embodies a view of marriage consonant with the commonlaw status of married women but repugnant to our present understanding of marriage and of the nature of the rights secured by the Constitution. Women do not lose their constitutionally protected liberty when they marry." 451

As Justices Blackmun and Stevens argued in partial dissent, the joint opinion was a conservative understanding of feminist politics, because it permitted a great deal of state regulation of women's choices that do not burden men's choices. ${ }^{452}$ But the joint opinion was also a far cry from the strict pro-life ideology, which received its classic judicial articulation in Justice Scalia's seething dissent, joined by four Justices. Echoing the view of the pro-life amici, Scalia denounced the Court for finding a "liberty" to destroy "a human life," without any

447. Casey, 505 U.S. at 846,873 (joint opinion).

448. Id. at 877. This was the test followed by Justice Powell in Maher, 432 U.S. at 473-74.

449. Casey, 505 U.S. at $882-83$ (written consent and information requirements); id. at 899-900 (parental consent).

450. "Regulations which do no more than create a structural mechanism by which the State, or the parent or guardian of a minor, may express profound respect for the life of the unborn are permitted, if they are not a substantial obstacle to the woman's exercise of the right to choose." Id. at 877.

451. Id. at 898 . in part).

452. Id. at 927-29 (Blackmun, J., dissenting in part); id. at 934-36 (Stevens, J., dissenting 
principled legal basis for justifying that move. ${ }^{453} \mathrm{He}$ insisted that this profoundly moral matter is the classic example of an issue best left to the democratically legitimate state legislative process, and that the elitist usurpation of decisionmaking by the Court was illegitimate..$^{454}$

Although most observers thought that Casey resolved the legal status of Roe $v$. Wade, the pro-life/pro-choice constitutional debate has continued and possibly escalated. The next wave of statutes reflecting traditionalist objections to Roe focused on certain mechanisms for late-term abortions, and these laws have produced emotional clashes in all levels of government. ${ }^{455}$ The Supreme Court ruled in Stenberg $v$. Carhart, ${ }^{456}$ that states could not ban all such mechanisms and could not ban any that did not have a broad exception giving physicians discretion to protect the health of the mother. Joined by four members of the Court, Justice Thomas's dissenting opinion described procedures allowed by the Court's decision in gruesome detail, analogizing them to "infanticide." ${ }^{457}$ Justice Scalia went further, describing the Court's authorization for "killing a human child" as a decision whose infamy would be equivalent to that of Dred Scott and Korematsu. ${ }^{458}$ Although Justice O'Connor provided a roadmap for states to enact partial birth abortion laws that would satisfy her (the critical fifth vote for the majority), ${ }^{459}$ there is little doubt that this new manifestation of the constitutional politics of abortion will occupy the country and the courts for some time to come.

b. The First Amendment Cases. The libertarian First Amendment, protective of women's interests in the family planning context, was a fulcrum for critique once feminists obtained state and federal legislation protecting their interests. Where feminists were most united and public opinion agreed with their agenda, the Court has applied the First Amendment cautiously. For example, many states and municipalities have barred "public accommodations" from discriminating on the basis of sex, and some have applied these laws to private clubs

453. Id. at 982 (Scalia, J., dissenting in part).

454. Id. at 996.

455. See Hope Clinic v. Ryan, 195 F.3d 857, 881 (7th Cir. 1999) (Posner, C.J., dissenting) (analyzing cynically the politics of partial birth abortion measures).

456. 530 U.S. 914 (2000), discussed in Section III.B.

457. Id. at 983-87 (Thomas, J., joined by Rehnquist, C.J., and Scalia \& Kennedy, JJ., dissenting) (noting that the procedure "so closely borders on infanticide that 30 States have attempted to ban it," a characterization repeated at 1020); id. at 983-87 (describing in detail the procedure, with the suggestion that this is surgical murder).

458. Id. at 953 (Scalia, J., dissenting). In a characteristically antic move, Scalia presented himself as a modern Cato, as he ended two consecutive paragraphs, and his dissenting opinion, with the refrain, "Casey must be overruled" (translatable as "Casey delenda est"). Id. at 955-56.

459. Id. at 947-51 (O'Connor, J., concurring). 
such as the Jaycees and the Rotary Club, which were all-male by national rule. ${ }^{460}$ In Roberts $v$. United States Jaycees, ${ }^{461}$ the Court recognized that the First Amendment protects the right of men to form "expressive" associations but failed to see how admitting women would undermine the expressive and associational interests of the Jaycees. ${ }^{462}$ Moreover, the Court ruled that whatever injury the law imposed on men's rights of association was justified by the important state antidiscrimination interest. ${ }^{463}$

In other areas, where feminists were themselves divided and the public less supportive, the Court has applied the First Amendment aggressively. The Court, for example, summarily affirmed Judge Frank Easterbrook's decision invalidating an Indianapolis law creating a tort cause of action for women injured by sexually explicit pornography that objectifies or degrades women. ${ }^{464}$ As Easterbrook's opinion emphasized, the ordinance regulated published materials that were not obscene (as the Court had defined the term) based on their content, the kind of regulation the First Amendment has traditionally rejected. Professor Catharine MacKinnon and other feminists had supported the ordinance as a measure needed for the protection of women against violence, and Indianapolis pressed their views on appeal. The ordinance regulated "speech" that is of the lowest value and results in great harm to women; under the Court's child pornography and indecent speech precedents, these demonstrated harms should have been sufficient to justify the ordinance, they maintained ${ }^{465}$ Even under strict scrutiny, the ordinance could be defended as needed to advance the compelling state interest in "eradicating sex discrimination," as in Roberts. ${ }^{466}$ The most powerful critics of these arguments have been

460. See, e.g., David E. Bernstein, Sex Discrimination Laws Versus Civil Liberties, 1999

U. CHI. LEGAL FoRUM 133.

461. 468 U.S. 609 (1984).

462. Id. at 627; accord Bd. of Dirs. of Rotary Int'l v. Rotary Club, 481 U.S. 537 (1987) (following Roberts). The Jaycees' brief probably did not help their cause much, as it was largely circular: the Jaycees defined themselves as a "young men's" association, and so their goals would axiomatically be impaired if "young women" were imposed upon them. See Brief of Appellee at 11-16, Roberts (No. 83-724). Their expressive association claim would have been stronger - but also probably less acceptable to their membership - if it had been that "our association stands for the idea that 'business is for guys." " $C f$. Brennan Conference Notes for Roberts, in Brennan Papers, supra note 129, Box I: 628, Folder 4 (Stevens: "Male chauvinists can't have protections unless they admit they are.").

463. Roberts, 468 U.S. at 623.

464. Hudnut v. Am. Booksellers Ass'n, Inc., 475 U.S. 1001 (1986), summarily aff'g 771 F.2d 323 (7th Cir. 1985).

465. Jurisdictional Statement at 11-15, Hudnut (No. 85-1090) (relying on New York v. Ferber, 458 U.S. 747 (1982) (child pornography)); Young v. Am. Mini-Theatres, 427 U.S. 50 (1976) (plurality opinion) (sexually explicit speech is low-value) as well as Catharine MacKinnon, Pornography, Civil Rights, and Speech, 20 HARV. C.R.-C.L. L. REV. 1 (1985)).

466. Jurisdictional Statement at 15-20, Hudnut (No. 85-1090). 
feminists, however. ${ }^{467}$ In the Indianapolis case, their only fans on the Supreme Court were its most traditionalist Justices. ${ }^{468}$

Hate speech codes have been even more controversial, because traditionalists as well as liberal feminists are skeptical of them. Defenders such as Professor Mari Matsuda maintain that such codes are constitutional because of their effect on third parties, especially people of color, women, and lesbigay people: hate speech literally disables them from participating in the political, social, and intellectual life of the community. ${ }^{469}$ Notwithstanding these powerful arguments, such codes are of dubious constitutionality after the Court's decision in R.A.V. v. City of St. Paul. ${ }^{470}$ The Court ruled that a hate crime law was overbroad because it penalized a lot of protected speech because of its expressive content, and indeed because of its viewpoint (denigration of racial or sexual minorities or women). Most judges - and many feminists - have understood this decision to be fatal to broadly written state hate speech laws.

Contrast the EEOC's Title VII guidelines regulating sexual harassment in the workplace. ${ }^{471}$ Like the anti-porn ordinance, these guidelines are drawn from the work of Professor MacKinnon and other early feminists. ${ }^{472}$ And their requirement that the employer not tolerate a "hostile work environment" has been interpreted to restrict speech as well as conduct that creates an environment hostile to women. Although libertarians have been consistently critical of these speech-restrictive rules, feminists and ordinary judges have disputed their tension with First Amendment values. ${ }^{43}$ Even Justice Scalia's opinion in R.A.V. was forced (by his colleagues no doubt) to concede that "sexually derogatory 'fighting words,' among other words, may produce a violation of Title VII's prohibition of sexual discrimination

467. See Lisa Duggan et al., False Promises: Feminist Anti-Pornography Legislation, 38 N.Y.L. SCH. L. REv. 133 (1993); Nicholas Wolfson, Eroticism, Obscenity, Pornography, and Free Speech, 60 BROOK. L. REV. 1037 (1994).

468. Within the Court, Burger, Rehnquist, and O'Connor - the most traditionalist Justices in 1986 - would have noted probable jurisdiction and heard arguments in the case. The other six Justices voted to affirm Easterbrook's opinion without briefing and argument. See Hudnut, 475 U.S. 1001.

469. Mari J. Matsuda, Public Response to Racist Speech: Considering the Victim's Story, 87 MICH. L. REV. 2320 (1989).

470. 505 U.S. 377 (1992).

471. EEOC Guidelines on Discrimination Because of Sex, 29 C.F.R. 1604.11(a); see Meritor Sav. Bank v. Vinson, 477 U.S. 57 (1986) (upholding these regulations).

472. Catharine A. MacKinnon, Sexual Harassment of Working Women: A CASE OF SEX DISCRIMINATION (1979).

473. Compare JefFrey Rosen, THe Unwanted Gaze (2001); Eugene Volokh, Freedom of Speech and Workplace Harassment, 39 UCLA L. REV. 1791 (1992), with Miranda Oshige McGowan, Certain Illusions About Speech: Why the Free Speech Critique of Hostile Work Environment Harassment Is Wrong, CoNST. COMM. (forthcoming 2002). 
in employment practices." ${ }^{474}$ This consensus has eroded: some feminists and judges are concerned that the breadth of the EEOC's guidelines or their too-aggressive implementation by employers are chilling sexual expression in the workplace. ${ }^{475}$

The most hotly contested area has involved pro-life activities. Frustrated by their mixed results from the legal system and the political process, pro-life activists formed more aggressive groups, the Pro-Life Action League (1980) and Operation Rescue (1986). These groups have engaged in an escalating campaign to picket abortion clinics and the homes of abortion doctors, to approach women entering clinics and persuade them not to proceed with abortions, and (in some instances) to assault abortion providers and damage the clinics. ${ }^{476}$ Prochoice activists objected that these activities intimidated both women seeking abortions and providers. ${ }^{477}$ In 1986, NOW sued the Pro-Life Action League for conspiring to interfere with its members' constitutional rights; Operation Rescue was added as a defendant in 1989. Abortion providers and their allies obtained injunctions all over the country; the orders typically enjoined protesters from blocking access to clinics, harassing women as they approached the clinics, and creating loud disturbances outside the clinics. ${ }^{478}$

Pro-life protesters objected that these injunctions violated their First Amendment rights. In Madsen v. Women's Health Center, ${ }^{479}$

474. R.A.V., 505 U.S, at 389 (emphasis added). Note Scalia's slip of the pen: "sexual" rather than "sex" discrimination. Id.

475. See, e.g., Saxe v. State College Area Sch. Dist., 240 F.3d 200 (3d Cir. 2001) (trimming back application of school district's sexual harassment guidelines in light of First Amendment values); Vicki Schultz, The Sanitized Workplace, 112 YALE L.J. (forthcoming 2002).

476. See Randall A. TERry, Operation Rescue (1988) (describing the philosophy of the organization's founder); Blanchard, supra note 406, at 51-60; Faye Ginsburg, Rescuing the Nation: Operation Rescue and the Rise of Anti-Abortion Militance, in ABORTION WARS: A HALF CENTURY OF STRUGGle, 1950-2000, at 227-50 (Rickie Solinger ed., 1998); Victoria Johnson, The Strategic Determinants of a Countermovement: The Emergence and Impact of Operation Rescue Blockades, in WAVES of Protest: SOCIAL MOVEMENTS SinCE THE SIXTIES 241, 245-65 (Jo Freeman \& Victoria Johnson eds., 1999).

477. See generally Abortion Clinic Violence: Oversight Hearings Before the Subcomm. on Civil \& Constitutional Rights of the House Comm. on the Judiciary, 99th Cong. (1985-86); Freedom of Access to Clinic Entrances Act of 1993: Hearings Before the Senate Comm. on Labor and Human Resources, 103d Cong. (1993).

478. See Brief of Amici Curiae NOW Legal Defense and Education Fund et al., Madsen v. Women's Health Ctr., 512 U.S. 753 (1994) (No. 93-880) (listing reported federal and state cases issuing or upholding such injunctions).

479. 512 U.S. 753 (1994), followed and applied in Schenck v. Pro-Choice Network of Western N.Y., 519 U.S. 357 (1997). An earlier case, Frisby v. Schultz, 487 U.S. 474 (1988), upheld an ordinance regulating residential picketing that had been aimed at pro-life protesters. Accord Bray v. Alexandria Women's Health Clinic, 506 U.S. 263 (1993) (holding that women have no $\$ 1985$ claim for relief against pro-life protesters conspiring to deny them access to abortion). 
Operation Rescue and counsel Jay Sekulow argued that the injunctions were prior restraints per se invalid under the First Amendment and, if not prior restraints, were substantive (and not time, place, or manner) restrictions on speech that were subject to strict scrutiny. ${ }^{480}$ Other amici associated Operation Rescue's protest activities with those of Susan B. Anthony, Martin Luther King, Jr., and early gay rights activists - a tradition of "civil disobedience" justifying judicial protection. ${ }^{481}$ Feminists and the clinic responded that the injunctions regulated conduct and likely violations of the law, not ideas, and therefore constituted ordinary time, place, and manner restrictions, traditionally subjected to rational basis inquiry. ${ }^{482}$

As it had in Casey, the Supreme Court chose a middle path to resolve the clash of norms. Chief Justice Rehnquist's opinion for the Court in Madsen ruled, with the clinic, that the injunction was neither a prior restraint nor a content-based regulation of the protesters but followed Operation Rescue in declining to characterize it as nothing more than a time, place, or manner restriction. Because injunctions "carry greater risks of censorship and discriminatory application" than statutes do, Rehnquist ruled that they require more exacting scrutiny than statutory time, place, and manner restrictions. "We must ask instead whether the challenged provisions of the injunction burden no more speech than is necessary to serve a significant government interest." 483 Applying the standard, the Chief Justice upheld the thirty-six-foot buffer zone in front of the clinic but invalidated other features of the injunction that were too broad. ${ }^{484}$

c. The National Campaign Against Sexual Harassment and Assault. Like civil rights activists, feminists have had strong incentives to nationalize their rights campaign: national laws and precedents offer the impressive enforcement resources of the federal government, can trump sexist policies still followed in the most traditionalist states (especially in the South), and present better possibilities for policies that actually redistribute power toward women. ${ }^{485}$ Nowhere has this been

\footnotetext{
480. See Brief of Amici Curiae Operation Rescue et al, at 4-15, Madsen (No. 93-880).

481. Brief of Amicus Curiae American Family Association at 4-11, Madsen (No. 93 -
} $880)$.

482. Brief for Respondents at 21-28, Madsen (No. 93-880).

483. Madsen, 512 U.S. at 764-65.

484. The Court followed and elaborated Madsen in Hill v. Colorado, 530 U.S. 703 (2000) (discussed in Section III.B) and Scheck v. Pro-Choice Network, 519 U.S. 357 (1997).

485. As to the last item, political scientists recognize that local governments are less likely to redistribute resources or rights, because they fear flight from traditionally empowered groups (especially rich people and corporations). At least in the 1960s, the flight problem was not so serious when regulation was national, and so redistributive legislation in the twentieth century tended to flourish at the national rather than local level. See PAUL Peterson, The Price of Federalism (1995). 
more important than in women's mobilization against gender-based violence. Recall the previous discussion of the EEOC's rules against sexual harassment in the workplace. Because of the civil rights movement's complete victory in legitimating Title VII as a proper exercise of congressional authority, this feminist effort did not encounter strong objection that it was an intrusion into areas best regulated by state and local governments. In contrast, feminist arguments that sexual harassment is illegal in educational institutions covered by Title IX, accepted by the Department of Education in 1998, have met with strong federalism-based resistance. Federalist critics concede that the federal government has broad discretion to set conditions on the funds it distributes to state educational institutions but argue that Title IX does not provide the states with adequate notice that their receipt of federal money carries with it potentially costly liability for sexual harassment lawsuits. ${ }^{486}$ As the new millennium opened, Title IX has been the subject of intense policy debates.

In contrast to sexual violence in the workplace, where national regulation is well-established, and in schools, where national regulation is justified by the receipt of federal funds, sexual violence in the bedroom has traditionally been the province of state and local governments. As scholars have shown, those governments have performed their functions poorly (and by some accounts scandalously). Even after states liberalized rape laws, women too often remain unprotected against sexual assault, either by strangers or (especially) boyfriends and spouses. ${ }^{487}$ Between 1990 and 1994, feminists and their allies developed a detailed record in a series of congressional hearings and reports, showing that women are pervasively subjected to violence because of their sex, that this pervasive violence not only affects women but also imposes enormous costs on the community and the economy, and that state law enforcement has been and remains inadequate to handle this level of gender-based violence. ${ }^{488}$ Based on this record, Congress enacted the Violence Against Women Act of 1994

486. Compare Davis v. Monroe County Bd. of Educ., 526 U.S. 629, 654 (1999) (Kennedy, J., dissenting) (making this argument as a basis for not rendering schools liable for hostile environment harassment), with id. at 632 (O'Connor, J., for the Court) (allowing a claim for relief, but defining it narrowly because of these federalism concerns).

487. There is an enormous literature on the prevalence of unremedied sexual assaults against women in America, including Diana E.H. Russell, SEXuAl ExPloitation: Rape, Child SeXual ABuse, AND WorkPlaCe Harassment (1984); Mary Koss et al., The Scope of Rape: Incidence and Prevalence of Sexual Aggression and Victimization in a National Sample of Higher Education Students, 55 J. CONSULTING \& CliniCAL PSYCHOL. 162 (1987). For a popular critique of these studies, see KATIE ROIPHE, THE MORNING AFTER: SEX, FEAR, AND FEMINISM ON CAMPUS (1993).

488. The congressional evidence is assembled, with references, in United States $v$. Morrison, 529 U.S. 598, 628-36 (2000) (Souter, J., dissenting). 
("VAWA"), which, inter alia, created a private claim for relief for "crimes of violence motivated by gender." 489

Although Congress justified its authority to enact VAWA upon the Commerce Clause and Fourteenth Amendment precedents that had sustained the Civil Rights Act ("CRA") and the Voting Rights Act ("VRA"), ${ }^{490}$ VAWA was different from the earlier laws. Unlike the VRA, which applied only to state and local governments, VAWA created a claim for relief against private violators; unlike the CRA, which applied to employers and public accommodations engaged in economic activities, VAWA reached defendants engaged in private noneconomic activity (sexual violence, usually in private places). To the extent the Court viewed the Commerce Clause as justifying federal regulation only of economic activity and the Fourteenth Amendment as justifying federal regulation only of state activity, VAWA was in constitutional trouble - and, not surprisingly, it reached the U.S. Supreme Court pretty quickly, as United States $v$. Morrison. ${ }^{491}$

In my view, the mountains of briefs in the case mechanically worked the precedents, which could have justified either result. ${ }^{492}$ In lawyerly fashion, VAWA defenders emphasized the desperate need for national enforcement of widely accepted norms against sexual assault, ${ }^{493}$ while critics argued that any theory supporting VAWA could be used to justify any exercise of congressional power, thereby eliminating federalism as a limit on Congress. ${ }^{494}$ An issue that received remarkably short shrift was the longstanding feminist charge that the ideas of traditional state sovereignty over domestic relations (relevant to the Commerce Clause power) and the state action doctrine (rele-

489. Violence Against Women Act, $\S 40302$, 108 Stat. 1941-42, codified at 42 U.S.C. $\S 13981$ (2002).

490. The precedents are discussed in Section II.E.2.

491. 529 U.S. 598 (2000), discussed in Section II.E.2.

492. That is, briefs supporting VAWA argued that the civil rights precedents supported federal lawmaking over any activity affecting commerce, Katzenbach v. McClung, 379 U.S. 294 (1965), or undermining equal access to state justice, United States v. Guest, 383 U.S. 745 (1966). Briefs attacking VAWA argued that newer federalism precedents did not allow Congress to regulate noneconomic activity under the Commerce Clause, United States v. Lopez, 514 U.S. 549, 559-60 (1995), or to regulate purely private activity under the Fourteenth Amendment, City of Boerne v. Flores, 521 U.S. 507 (1997) (reaffirming The Civil Rights Cases, 109 U.S. 3 (1883)).

493. See Brief of Petitioner at 6-18, 26-32, 42-45, Morrison v. United States, 529 U.S. 598 (2000) (Nos. 99-5, 99-29); Brief of Amici Curiae States of Arizona [and 35 other states and Puerto Rico] in Support of Petitioner's Brief on the Merits at 5-9, 15-21, Morrison (Nos. 99 5, 99-29); Brief of Amici Curiae Law Professors in Support of Petitioners at 7-12, 18-23, Morrison (Nos. 99-5, 99-29).

494. See Brief of Amicus Curiae Eagle Forum Education \& Legal Defense Fund in Support of Respondents, Morrison (Nos. 99-5, 99-29). 
vant to the Fourteenth Amendment power) mimicked the separate spheres construct that has long retarded women's equality. That is, the traditional relegation of women to the domestic sphere finds parallels in the presumption against national regulation of domestic relations or of private discriminations and violence. The spaces where women are most centrally located and most vulnerable are those least constitutionally susceptible to national regulation that is much more efficacious. In contrast, the public spheres of commerce and state action where men have been and remain dominant - are spaces where the Court has authorized Congress to act, partly in response to cases brought by the male-dominated civil rights movement.

Although one may doubt the Justices would have been receptive to this kind of theoretical argument, it does help us understand the consequences of the Court's 5-4 ruling striking down the law. Rejecting the feminist position taken by thirty-six states, Chief Justice Rehnquist's opinion for the Morrison Court strictly followed the arguments laid out in the briefs for the defendants and the amicus brief for Phyllis Schlafly's Eagle Forum. This was an important defeat for women's politics of recognition as well as remediation: not only will sexual assault laws continue to be greatly underenforced, but the separate spheres idea got an unexpected boost from the Court, which specifically targeted "family law" as an arena limited to state regulation. ${ }^{495}$ Conversely, Morrison is an important victory for the politics of preservation's effort to localize antidiscrimination law. A consequence is that feminist efforts to redistribute resources to protect women will continue to be thwarted by obstacles inherent to local governance.

\section{Gay Rights Movement}

Unlike the civil rights and women's rights movements, which had rich conceptual and political antecedents in the nineteenth century, the gay rights movement was entirely a creature of the twentieth century. Although states criminalized sodomy and municipalities made cross-dressing a minor crime before 1900, "homosexual sodomy" and "homosexuality" were not objects of state regulation until the early twentieth century. ${ }^{496}$ But once the state focused on "homosexuals and

495. Morrison, 529 U.S. at 615-16 (noting that a danger of accepting Congress's understanding of the Commerce Clause is that it could "be applied equally as well to family law and other areas of traditional state regulation").

496. For this regulatory shift, see ESKRIDGE, GAYLAW, supra note 14, at 17-56; LILLIAN FADERMAN, ODD GIRLS AND TWILIGHT LOVERS: A HISTORY OF LESBIAN LIFE IN TWENTIETH CENTURY AMERICA (1991); ANgus MClaren, ThE Trials OF MASCULINITY: POliCING SEXUAL BoundariES, 1870-1930 (1997); and Estelle Freedman, "Uncontrolled Desires": The Response to the Sexual Psychopath, 1920-1960, 74 J. AM. HIST. 83 (1987). 
sex perverts," it did so with a vengeance. At the height of America's anti-homosexual terror, the half-generation after World War II, the state not only hunted and jailed "homosexuals" for cross-dressing and having sex with one another, but kicked them out of the civil service, closed their bars and hangouts, seized novels and journals about their "perversion," censored movies that mentioned the crime that dared not speak its name, deported them, and locked them in hospitals where they were electroshocked, castrated, and otherwise tortured. ${ }^{497}$

Before the anti-homosexual Kulturkampf, there was little homophile politics of any sort - there were frightened individuals seeking to avoid disclosure, tiny subcultural communities concentrated in the larger cities, and isolated institutions such as bars and publishers who catered to a lesbigay clientele. State persecution stimulated a nascent politics of protection after 1945, as "homosexuals" and their subcultural institutions not only started to resist their persecution, but did so through organizations and lawyers that asserted their rights in court. Both the persecution and the resistance encouraged a larger number of gay people to "come out of the closet" in the 1960s, a process that spawned a tiny but influential politics of recognition, modeled on the civil rights experience and claiming that homosexuality is a benign variation, rather than the malignant one portrayed by the law. Because openly lesbigay people have been a minuscule (and later small) minority of the American population, and an intensely hated minority to this day, they have relied on lawyers to assert their interests more than women and perhaps even people of color have in the last generation. Unlike the civil rights and women's movements, moreover, the gay rights movement has been far from successful in its politics of recognition: not only do many state and even national laws and policies disadvantage lesbigays as a practical matter, many openly disrespect Americans because of their minority sexual orientation. ${ }^{498}$ On the other hand, in municipalities and an increasing number of gay-friendly states, a lesbigay politics of remediation has been successful in obtaining state protection for sexual and gender minorities.

The slow and to this day uncertain progress of a progay politics of recognition and remediation owes much to the average person's association of lesbigay people with sodomy and other sexual activities. Ac-

497. On the postwar anti-homosexual persecution, see ALLAN BÉRUBÉ, COMING OUT UNDER Fire: THE History OF GAY MEN AND WOMEN IN WORLD WAR TWO (1990); John D'Emilio, Sexual Politics, Sexual Communities: The Making OF A HOMOSEXUAL MINORITY IN THE UNITED STATES, 1940-1970 (1983); ESKRIDGE, GAYLAW, supra note 14, at 57-80; JONATHAN NED KATZ, GAY AMERICAN HISTORY (1976) (reproducing many primary documents); and George Chauncey, Jr., The Postwar Sex Crime Panic, in TRUE STORIES FROM THE AMERICAN PAST 160 (William Graebner ed., 1993).

498. Antigay laws and policies as of 1998 are collected (with references) in ESKRIDGE, GAYLAW, supra note 14, at 139-41, 362-71 (app. B3). 
cordingly, lesbigay people's political and constitutional struggles have tended to be more like the politics of abortion than the politics of equal rights for women and people of color. Like the (intimately related) pro-life countermovement, the traditional family values ("TFV") countermovement focuses on the asserted immorality of specific conduct (consensual sodomy) to deny individuals rights and, when this argument runs out, falls back on "no promotion" arguments: even if the state cannot criminalize consensual same-sex intimacy, it can adopt numerous measures to discourage or signal its disapproval of such controversial activities. Ongoing clashes between gay rights and family values form one of the cutting edges of American constitutional law at the dawn of the new millennium.

\section{The Politics of Protection, 1946-69}

"Homosexuals" and cross-dressers were legally defenseless but were mostly left alone by the law before World War II. The two phenomena were interrelated: so long as they were left alone, these Americans were not even an identity-based "minority group." This changed with the postwar anti-homosexual terror, for it landed many lesbigay people in prison, outed them and others, and triggered a moderate "homophile" politics seeking constitutional protection of private gay spaces. ${ }^{499}$ That politics relied on the libertarian features of the Due Process Clause and the First Amendment, at the very point when the civil rights and free press movements were giving these constitutional provisions real bite. For a dramatic example, the earliest public triumph of the Mattachine Society of Los Angeles, the first substantial homophile group, was a campaign against police entrapment of one of their members through aggressive sting operations. ${ }^{500}$ In this and other campaigns, the Mattachine Society, and its sister the Daughters of Bilitis, conceded gay people's condition as tragic but claimed basic civil liberties.

Unlike the early civil rights and women's movements, the homophile movement relied most successfully on the First Amendment. State censorship of "degenerate" or "perverted" books, plays, and movies was particularly common, because traditionalists were squeamish about any favorable or even neutral public discussion of "sexual deviation," while lesbigay people were thirsty for information about sexual variation and saw their despised status as one based on

499. On the early homophile politics, see D'EMILIO, supra note 497; STUART TIMMONS, The Trouble WITH HARRY HAY (1990). See also ERIC MARCUS, MAKING HISTORY: THE STRUGGLE FOR GAY AND LESBIAN EQUAL RIGHTS 32-36, 40-41, 50-53, 62-63, 111-13 (1992) (providing various first-person accounts by early homophile leaders).

500. See Dale Jennings, To Be Accused Is to Be Guilty, ONE, INC., Jan. 1953, at 11-12 (providing first-hand account). 
society's misinformation. ${ }^{501}$ State and lower federal courts had sometimes ruled against censorship of gay-friendly or gay-neutral materials before World War II. For example, New York's state courts overturned local censorship of Sholom Asch's lesbian-themed God of Vengeance, gay writer André Gide's autobiography, and Radclyffe Hall's lesbian classic, Well of Loneliness. ${ }^{502}$ In retrospect, these few protected works were pretty tame discussions of sexual variation; the authorities wished to censor them because they spoke of homosexuality as a natural rather than sinful phenomenon, a benign or at worst tolerable sexual variation. After the war, more provocative literary depictions of sexual variants tested the limits of the First Amendment. Most lesbigay-depicting novels either passed unnoticed by the censors or were suppressed without much fuss, but in the 1950s aggressive censors confronted more in-your-face gay works such as Allen Ginsburg's homoerotic poem "Howl" and Herman Womack's male physique magazines, both of which were suppressed by state authorities and then liberated by the courts. ${ }^{503}$

These legal questions first reached the Supreme Court in the most innocuous setting imaginable. The U.S. Post Office seized the October 1954 issue of One, Inc., the earliest homophile informational magazine..$^{504}$ The Post Office claimed that the magazine's brief, generalized depiction of a potential lesbian romance ("Sappho Remembered"), a dirty poem, and an advertisement for a German magazine were obscene; the Ninth Circuit agreed, on the ground that vulnerable minds could be corrupted by these materials. ${ }^{505}$ One appealed to the Supreme

501. For accounts of the battle by gay people to express themselves and society to shut them up in various fora, see Roger AUSTEN, Playing THE GAME: THE HOMOSEXUAL Novel IN AMERICA (1977); KAIER CuRTIN, "We CAN AlWAYS Call THEM Bulgarians": THE EMERgence of Lesbian and Gay Men on the AMERICAN Stage (1987); and RODGER STREITMATTER, UNSPEAKABLE: THE RISE OF A GAY AND LESBIAN PRESS IN AMERICA (1995). On the legal struggle, see ESKRIDGE, GAYLAW, supra note 14, at 32-34, 46-49, 76-78, 95-96, 116-23. See also id. at 80-82 (suggesting chilling parallels between Nazi suppression of homosexual expression and similar suppressive measures in America after the war against the Nazis).

502. For the stories of these works' censorship and state court action, see ESKRIDGE, GAYLAW, supra note 14, at 33, 47-48; Nancy J. Knauer, Homosexuality as Contagion: From The Well of Loneliness to the Boy Scouts, 29 HOFSTRA L. REV. 401, $430-54$ (2000) (offering detailed analytical account of Well's obscenity trials in both the U.S. and U.K.). Most gaythemed works either passed without censorial notice or, if discovered, were successfully censored before World War II, however. See ESKRIDGE, GAYLAW, supra note 14, at 46-49 (providing examples).

503. Womack's work is treated below; Ginsburg's in Section II.F.2.

504. For two slightly different accounts of this episode, compare STREITMATTER, supra note 501, at 32, with MARCUS, supra note 499, at 52-53 (providing first-person account years after the events).

505. One, Inc. v. Olesen, 241 F.2d 772 (9th Cir. 1957), rev'd, 355 U.S. 371 (1958) (per curiam). 
Court, on the ground that "[w]orks which attempt to elucidate, explain or grapple with thorny and fundamental human problems should be extended great latitude of expression, since they often, in the last analysis, serve humanity's ends." Apologetically, Eric Julber's brief submitted that the magazine never included lewd sexual references nor even any "advocacy of homosexuality as a way of life"; it just proffered discussion of the issues associated with "that particular neurosis, or complexion." 506

Right after Julber filed his brief, the Court decided Roth $v$. United States ${ }^{507}$ which held that the state could not censor a publication as "obscene" unless, considered as a whole, its predominant appeal is to the audience's prurient interest and its presentation exceeds customary limits. Was a lesbian romance inherently prurient in ways that straight ones were not? As one law clerk put it,

The [appeals] court seems to feel that homosexuality is disgusting and therefore allusions to homosexual practices are disgusting and obscene... I think One is no more descriptive of sexual practices than dozens of magazines. The fact that the practices differ from those of the "normal" person should not make the magazine obscene. ${ }^{508}$

We do not know exactly how the Justices viewed the case, but they voted with no recorded dissent to reverse the Ninth Circuit's decision and to direct that judgment be awarded to the homophile publication on the basis of Roth. ${ }^{509}$

The Post Office's campaign also included male physique magazines, which government psychiatrists believed had a prurient appeal to male homosexuals. In Manual Enterprises, Inc. v. Day, ${ }^{510}$ Herman Womack challenged the government's targeting several of his magazines (MANual, Grecian Guild Pictorial) under Roth. Stanley Dietz's

506. Petition for Writ of Certiorari at 8, One, Inc. v. Olesen, 355 U.S. 371 (1958) (1957 Term, No. 290).

507. 354 U.S. 476 (1957), discussed in Section II.F.2.

508. Law Clerks' Memoranda for One, Inc. (1957 Term), in Burton Papers, supra note 249, Container 298 (No. 290). Another law clerk professed himself "torn between the desire to cut down on this sort of administrative censorship and the revulsion the magazine gives me." However, he opined that "in the long run it is better to let the American people make the choice than a postmaster." Office Memos for One, Inc. (Aug. 26, 1957), in Douglas Papers, supra note 192, Container 1187.

509. One, Inc. v. Olesen, 355 U.S. 371 (1958) (per curiam) (reversing on the basis of Roth v. United States, 354 U.S. 476 (1957)). According to Justice Douglas' docket book, six Justices voted to take the case on January 3, 1958, with four Justices (Frankfurter, Douglas, Harlan, and Whittaker) reversing summarily, rather than remanding for the lower court to reconsider in light of Roth. (There is no notation for how three Justices voted.) A week later, Justice Clark, who voted against certiorari the week before, voted with the Frankfurter group to reverse outright. See Docket Book for One, Inc. (Jan. 13, 1958), in Douglas Papers, supra note 192, Container 1184.

510. 370 U.S. 478 (1962), described and analyzed by JOYCE MURDOCH \& DEB PRICE, Courting Justice: Gay Men and Lesbians v. The Supreme Court 65-88 (2001). 
brief for Womack charged the Post Office with "nothing more than an attempt to enforce the prejudices of the predominant social and economic majority over a minority group." If the state could censor images based on their prurient appeal alone, then the Post Office could seize suggestive pin-up photographs of Marilyn Monroe, Dietz argued. ${ }^{511}$ Solicitor General Archibald Cox's brief responded that the state could censor any kind of scantily-clad pin-ups and, in any event, that homophile pin-ups are more dangerous to society because "homosexuals are more easily stimulated to overt sexual activities than are normal persons with heterosexual outlooks. Finally, it seems scarcely open to question that society has a legitimate interest," expressed in state sodomy laws, "in preventing overt homosexual activities while refusing to condemn comparable activities when indulged in on a heterosexual basis." ${ }^{12}$ Dietz's oral argument in Manual Enterprises was the Justices' first face-to-face encounter with constitutional issues raised by sexual minorities. There is no evidence that anyone on the Court learned anything from the encounter. Justice Harlan's plurality opinion reversed the censorship because the pictures were not inherently "prurient" according to contemporary standards of decency ${ }^{513}$ but gratuitously described the magazines as "dismally unpleasant, uncouth, and tawdry" and their readers as "unfortunate persons." 514 Justice Clark's dissenting opinion lamented that the Post Office was now required to be "the world's largest disseminator of smut." ${ }^{515}$ The Supreme Court in the 1960s and 1970s repeatedly addressed state and local censorship of publications depicting homosexual intimacy more directly. The Court sometimes protected gay erotica against censorship, but often treated gay erotica more harshly than straight. ${ }^{516}$

Lesbigay people could invoke the speech and press protections of the First Amendment to protect discussion about homosexuality, in-

511. Brief for Appellant at 23 (quotation in text), 27-28, Manual Enterprises (1961 Term, No. 123).

512. Brief for the Respondent at 44-45, Manual Enterprises (1961 Term, No. 123); see id. at 27 (making similar argument that "pornographic material directed to sexual deviates is more likely to induce overt sexual activity than such material directed to the normal sexual impulses").

513. Manual Enterprises, 370 U.S. 478 (Harlan, J., joined by Stewart, J.). Four Justices concurred in the result. Id. at 495 (Black, J., concurring in the result); $i d$. at 495-519 (Brennan, J., joined by Warren, C.J., and Douglas, J., concurring in the judgment) (rejecting the Post Office's authority to censor).

514. Id. at 490 (opinion by Harlan, J.).

515. Id. at 519 (Clark, J., dissenting). "The magazines have no social, educational, or entertainment qualities but are designed solely as sex stimulants for homosexuals." Id. at 526.

516. See infra Section II.F.2. 
cluding autobiographical discussion. ${ }^{517}$ They could also invoke the assembly provision to protect their ability to gather together. Indeed, the NAACP's right of association cases made it unlikely that the state would directly prosecute homophile organizations. Most of the litigation arose in the context of state efforts to revoke liquor licenses from bars catering to lesbian or gay clientele. Unlike individual gay people, the bars had resources to resist such efforts, and sometimes state courts would intervene. The California Supreme Court in Stoumen v. Reilly ${ }^{518}$ ruled that regulators could not deny licenses to bars simply because of "patronage ... by homosexuals ... without proof of the commission of illegal or immoral acts on the premises." ${ }^{519}$ Because the constitutional basis for this ruling was unclear, the legislature adopted a law barring licenses to establishments that were reputed to be resorts for "sexual perverts." 520 In Vallerga $v$. Department of Alcoholic Beverage Control, ${ }^{521}$ the California Supreme Court invalidated this law as a violation of gay people's constitutional right to association, just as Mitchell and Juliet Lowenthal had argued in their amicus brief filed on behalf of the ACLU. As Vallerga suggests, ACLU-affiliated attorneys sometimes represented lesbigay defendants in the 1950s and early 1960 s, even though the national ACLU was on record in favor of sodomy laws.

The Due Process Clause had a lot less bite for the homophile politics of protection than it had for people of color, because almost all the "homosexuals" arrested by police dragnets and stings were either released immediately or plea bargained to a mild punishment without a constitutional peep. ${ }^{522}$ The biggest value of due process was prophylactic: homophile groups made gay people aware of their procedural rights, especially their right to remain silent and to retain counsel (later provided free by the state). ${ }^{523}$ Once an accused "homosexual"

517. See, e.g., People ex rel. Savery v. Gotham Book Mart, Inc., 285 N.Y.S 563 (NYC Magis. Ct. 1936) (protecting André Gide's autobiography against censorship).

518. 234 P.2d 969 (Cal. 1951).

519. Id. at 971; see William N. Eskridge, Jr., Privacy Jurisprudence and the Apartheid of the Closet, 1946-1961, 24 FLA. ST. U. L. REV. 703, 752-53 (1997) (discussing the California gay bar cases). 1997).

520. Law of 1955, CAL. BUS. \& PROF'L CODE ANN., § 24200(e) (repealed 1963) (West

521. 347 P.2d 909 (Cal. 1959).

522. See, e.g., Charles K. Robinson, The Raid, ONE, INC., July 1960, at 26 (state judge complaining that homosexual defendants pleaded guilty to charges even the prosecution was willing to drop). It must be noted that most of the lesbigay defendants rounded up by the police faced relatively mild punishments (a short time in jail), in contrast to the death sentences often meted out to men of color.

523. See Your Rights in Case of Arrest, ONE, INC., Jan. 1954, at 14 (publishing handy list of constitutional rights of criminal defendants, and advice to lesbigays harassed or arrested by the police). 
lawyered up, he or she could usually escape jail time and even any kind of conviction. When defendants were brave enough to contest charges of consensual sodomy or solicitation in court, there were often winning due process defenses: the police entrapped the defendant or obtained evidence illegally; there was not sufficient evidence to sustain a conviction; or the substantive statute was too vague to provide adequate notice to defendants that their conduct was criminal. ${ }^{524}$ The vagueness argument, of course, could inure to the benefit of all gay people, and not just the defendant in the particular case. State courts were particularly hard on cross-dressing and, to a lesser extent, vagrancy and solicitation laws. ${ }^{525}$ Several courts invalidated or narrowly construed their crime against nature laws. ${ }^{526}$

Unlike the First Amendment, the Due Process Clause offered no protection for gay people in the U.S. Supreme Court, however. The Court's first struggle with such issues involved the immigration law's exclusion of aliens "afflicted with psychopathic personality." The administering agencies interpreted that language to exclude all "homosexuals and sex perverts," and sought to deport George Fleuti, a sodomite. His counsel introduced psychiatric evidence that sexual variation was not sufficient to justify a diagnosis of "psychopathy." Demonstrating that the term did not even have an accepted meaning among psychiatrists, the Ninth Circuit in Fleuti v. Rosenberg ${ }^{527}$ ruled that the statutory language was too imprecise to justify exclusion or deportation of gay people as a group. On appeal, the Supreme Court was deeply split, with four Justices finding the statute unconstitutionally vague, but five unpersuaded. The decisive vote in conference came from newly appointed Justice Arthur Goldberg, who believed that Fleuti's arrests for sex in public places rendered him "a psychopath in the conventional sense. ${ }^{.528}$ Goldberg was assigned the opinion for the Court, but on further deliberation changed his mind. He proposed that the Ninth Circuit's refusal of deportation be affirmed on a narrow statutory ground; the four Justices formerly in the minority joined his opinion, with one important change of language. ${ }^{529}$ So Fleuti

524. See ESKRIDGE, GAYLAW supra note 14, at 84-90 (discussing these challenges).

525. See id. at 109-11 (surveying state court opinions striking down these laws).

526. See Harris v. State, 457 P.2d 638 (Alaska 1969); Franklin v. State, 257 So.2d 21 (Fla. 1971); Commonwealth v. Balthazar, 318 N.E.2d 478 (Mass. 1974).

527. 302 F.2d 652, 657-58 (9th Cir. 1962), aff'd on other grounds, 374 U.S. 449 (1963), also discussed in Section II.A.3. See generally MURDOCH \& PRICE, supra note 510, at 85-101 (giving more background on Fleuti).

528. Conference Notes for Fleuti v. Rosenberg (Apr. 17, 1962), in Douglas Papers, supra note 192, Container 1281.

529. Fleuti v. Rosenberg, 374 U.S. 449 (1963). At the urging of Justice Brennan, Justice Goldberg changed this sentence, "Congress unquestionably has the power to exclude homosexuals and other undesirables from this country," to omit "homosexuals and other." See 
was able to stay in the United States, but the immigration authorities continued their campaign against others.

Responding to the Ninth Circuit opinion, Congress amended the law to exclude people "afflicted with ... sexual deviation" as well. When the "psychopathic personality" issue returned to the Supreme Court in Boutilier v. INS ${ }^{530}$ the Justices were less divided: even though the bisexual Canadian was deported under the old psychopathic personality exclusion (before the new amendment took effect), at least two of the Justices gave up on their vagueness objection in light of Congress's subsequent clarification. ${ }^{531}$ The majority opinion, by Justice Clark (the solo dissenter in Manual), lumped all homosexuals and the apparently bisexual Boutilier into the statutory category of "psychopaths." The most sympathy lesbigay people could find from the Court was Justice Douglas's lament, in his draft dissent, that "homosexuals" are "just as much the victims of their constitutions as we are of ours, and we can only step in when their conduct becomes subversive of society, or when they request help so as to enable them to reach a more mature level." 532

The Court was also unreceptive to vagueness challenges to laws criminalizing "lewd conduct" 533 or the "crime against nature." Although the crime against nature might mean almost anything (or nothing), the Court ultimately ruled, in a perfunctory per curiam opinion, that the term had acquired sufficient clarity through longstanding judicial construction and popular understanding to pass the vagueness test. ${ }^{534} \mathrm{~A}$ potentially stronger challenge to such laws lay in the right of privacy recognized in Griswold and Roe. The American Law Institute ("ALI") in 1955 had taken the position that sodomy be-

Letter from William J. Brennan, Jr., to Justice Goldberg re: Fleuti (June 6, 1963), in Brennan Papers, supra note 129, Box I: 91, Folder 5. Said Brennan: "[I] think it may be, at least medically, a matter of doubt whether homosexuals also necessarily fall into the category of undesirable aliens." Id.

530. 387 U.S. 118 (1967); see William N. Eskridge, Jr., Gadamer/Statutory Interpretation, 90 COLUM. L. REV. 609 (1990) (putting forth a detailed examination of the statutory interpretation arguments in Boutilier).

531. According to Justice Douglas' notes, Justice Black, who had found the psychopathic personality term too vague in Fleuti, found it clear enough the next time around to say that "psychopathic personality means sexual deviate," the term added in 1965. Douglas Conference Notes for Boutilier (Mar. 17, 1967), in Douglas Papers, supra note 192, Container 1391. Chief Justice Warren continued to believe that "a homo immigrant might not be psychotic," $i d$., but he ultimately joined the majority opinion upholding Boutilier's deportation.

532. Draft Dissenting Opinion for Boutilier at 2 (Mar. 17, 1967), in Douglas Papers, supra note 192, Container 1391. The language quoted in text was deleted in the published dissent.

533. See Talley v. California, 390 U.S. 1031 (1968) (denying certiorari to gay couples' challenge to a "lewd conduct" arrest for kissing one another in the Black Cat Bar).

534. Wainwright v. Stone, 414 U.S. 21 (1973) (per curiam), followed in Rose v. Locke, 423 U.S. 48 (1975). 
tween consenting adults should be decriminalized as a matter of private liberty rather than public concern. ${ }^{535}$ After Griswold, the ACLU took the position that the right of privacy required states to follow the ALI. After Roe, the ACLU brought a class action challenging Virginia's sodomy law as a violation of the right of privacy and the First Amendment rights of association, thought, and expression. ${ }^{536}$ The Supreme Court in 1976 summarily (without full briefing and oral argument) affirmed the lower court decision upholding the law. ${ }^{537}$

Not only could the state constitutionally imprison someone for engaging in oral or anal sex with a consenting adult, but for the most part the courts allowed the state to exclude lesbigay people from civil service employment. For a dramatic example, the Civil Service Commission ("CSC") dismissed Dr. Franklin Kameny, a Harvardtrained astronomer, for failing to report that he had been arrested in 1956 for allegedly soliciting sex from an undercover police officer. ${ }^{538}$ That Kameny lost his job over a minor incident suggesting his homosexuality was nothing new in the period after World War II ${ }^{539}$ What was unusual was Kameny's response: he sued the federal government to get his job back. His attorney, Byron Scott, maintained that the government's action was arbitrary and therefore a violation of the Due Process Clause. The federal courts summarily dismissed this complaint. Kameny filed a pro se petition for writ of certiorari with the U.S. Supreme Court on January 27, 1961. Like his attorney in the courts below, Kameny made standard due process arguments: the government's decision to fire him and bar him from further employment was not sufficiently supported by the facts of his case, did not follow the proper procedures, and operated under a substantively unsupportable rule barring federal employment of people who commit "immoral conduct." ${ }^{540}$ Not only was the "immoral conduct" bar vague,

535. See Model Penal Code $\$ 207.5$ comments (Tent. Draft No. 4, 1955).

536. See Jurisdictional Statement at 7-11, Brief of American Civil Liberties Union, Doe v. Commonwealth's Attorney, 425 U.S. 901 (1976) (No. 75-896) (asserting Supreme Court's jurisdiction to review three-judge court's refusal to invalidate sodomy law).

537. Doe v. Commonwealth's Attorney, 425 U.S. 901 (1976) (per curiam), aff'g mem., 403 F. Supp. 1199 (E.D. Va. 1975) (three-judge court); see Consolidated Petition for Rehearing, Doe (No. 75-896) and Enslin v. North Carolina, 425 U.S. 985 (1976) (No. 75-897).

538. In return for a guilty plea to a charge of lewd conduct, the court sentenced Kameny to probation. After he completed the probation, the court granted his motion to withdraw the guilty plea and substitute a note of dismissal. Kameny therefore felt justified in not disclosing the expunged arrest. See Petition for a Writ of Certiorari at 6-9, Kameny v. Brucker, 365 U.S. 843 (1961) (1960 Term, No. 676); Brief for the Respondents in Opposition at 3-4 \& n.4, Kameny (1960 Term, No. 676).

539. See Note, Government-Created Employment Disabilities of the Homosexual, 82 HARV. L. REV. 1738 (1969).

540. See Brief for Petititoner at 24-26, Kameny (1960 Term, No. 676) (quoting 5 C.F.R. $\S$ $2.106(\mathrm{a})(3)$ (CSC regulation)). 
but it imposed an "odious conformity" upon federal employees, inconsistent with the First Amendment. ${ }^{541}$ This petition was the first time the Supreme Court had seen a challenge to state exclusions of gay people from the civil service. The Court denied the petition, without either internal or written dissent. ${ }^{542}$

\section{The Birth of a Politics of Recognition, 1961-81}

Futile as it was, Kameny's petition to the Supreme Court was a landmark in the politics as well as constitutional discourse of gay people. Kameny also argued that the federal government's broad exclusion from employment "makes of the homosexual a second-rate citizen, by discriminating against him without reasonable cause." ${ }^{543}$ There was, for example, no scientific basis for the belief that "homosexuals" were psychopathic. "The average homosexual is as well-adjusted in personality as the average heterosexual." 544 Because such persons are capable of excellent government service, excluding them is presumptively irrational. The federal government should be doing precisely the opposite: "One role of government is to stimulate changes in attitude.' In fields of anti-Negro, Anti-Semitic, anti-Catholic, and other prejudice, the government has indeed recognized, and is playing fully and admirably its role as a leader of changes in attitude." ${ }^{45}$ The CSC's exclusion, Kameny argued, "constitute[s] a discrimination no less illegal and no less odious than discrimination based upon religious or racial grounds ...."546

The ideas in Kameny's brief were revolutionary and important. The brief was an announcement that the objects of the postwar antihomosexual Kulturkampf were insisting on equal citizenship and not just an easing of persecution. It was the beginning of a serious politics of recognition and even remediation for lesbigay people, and this rapidly eclipsed the apologetic homophile politics of protection of the

541. Id. at 27; see id. at 28-29. For an updated version of Kameny's argument, see David Cole \& William N. Eskridge, Jr., From Hand-Holding to Sodomy: First Amendment Protection of Homosexual (Expressive) Conduct, 29 HARV. C.R.-C.L. L. REV. 319 (1994).

542. Kameny, 365 U.S. 843. The docket sheet kept by Justice Brennan revealed no Justice willing to hear Kameny's case.

543. Brief for Petitioner at 32, Kameny (1960 Term, No. 676). For the historical context of Kameny's revolutionary brief, see David K. Johnson, "Homosexual Citizens": Washington's Gay Community Confronts the Civil Service, WASH. HIST., Fall-Winter 1994-1995, at 52. An important normative precursor to the egalitarian arguments was DONALD WEBSTER CORY, THE HomoseXuAl IN AMERICA: A SUBJECTIVE APPROACH (1951).

544. Brief for Petitioner at 37, Kameny (1960 Term, No. 676).

545. Id. at $49-50$.

546. Id. at 56; see id. at 59 (calling exclusionary policy "a stench in the nostrils of decent people, an offense against morality"). 
1950s. After filing his petition, Kameny founded the Mattachine Society of Washington, D.C. ("MSW"), which expressed this philosophy in a letter to Attorney General Robert Kennedy:

We feel that, for the $15,000,000$ American homosexuals, we are in much the same position as the NAACP is in for the Negro, except for the minor difference that the Negro is fighting official prejudice and discrimination at the state and local level, whereas we are fighting official prejudice and discriminatory policy and practice, as ill-founded, as unreasonable, as unrealistic, and as harmful to society and to the nation, at the Federal level. Both are fighting personal prejudice at all levels. For these reasons, and because we are trying to improve the position of a large group of citizens presently relegated to second-class citizenship in many respects, we should have, if anything, the assistance of the Federal government, and not its opposition. ${ }^{547}$

Other groups, such as San Francisco's Society for Individual Rights and New York's Mattachine Society, took similar positions. In February 1966, the First National Planning Conference of Homophile Organizations resolved: "Homosexual American citizens should have precise equality with all other citizens before the law and are entitled to social and economic equality of opportunity." ${ }^{248}$ By the late 1960 s, Kameny's slogan "Gay is Good" had become the rallying cry for gay activists.

Kameny's pro se brief was the first time a litigant before the Court had challenged the compulsory heterosexuality requirement for federal employment or other benefits. It was the first brief before the Supreme Court to argue that homosexuality was a benign variation, that "homosexuals" were a minority group like Jews and African Americans, that anti-homosexual discrimination was fundamentally based on prejudice rather than a neutral policy, and that the equal protection component of the Fifth Amendment barred discrimination on the basis of sexual variation. Lawyers representing lesbigays picked up on some of Kameny's ideas. For example, in Manual Enterprises, Stanley Dietz challenged the Kennedy Administration's view that gay erotica should be treated differently from straight: "Our Constitution does not state that only heterosexuals may receive and read the literature of their choice and homosexuals must read the same literature or

547. Letter from Franklin E. Kameny, President, The Mattachine Society of Washington, D.C., to Robert F. Kennedy, Attorney General 1 (June 28, 1962) (on file with the FBI, FOIA File HQ 100-403320 (Mattachine Society) § 6, Serial No. 88); see also News Release, Mattachine Society of Washington, D.C. (Aug. 28, 1962) (on file with the FBI, FOIA File HQ 100-403320 (Mattachine Society) § 6, Serial No. 90X) (insisting on the same constitutional rights for "the homosexual minority - a minority in no way different, as such, from other of our national minority groups. ...").

548. U.S. Homophile Movement Gains National Strength, THE LADDER, Apr. 1966, at 4 (quoting the conference's resolutions). 
be denied the right to view a magazine which interests them. To interpret our Constitution... in the manner that the Post Office Department has done, reduces a large segment of our society to second class citizenship." 549 To the Solicitor General's suggestion that lesbigay people are sick, Dietz responded that, according to modern science, homosexuality is neither a disease nor a mental defect, "nor is homosexuality as such intrinsically evil." 550 The same kind of arguments were made by the attorneys for George Fleuti and Clive Michael Boutilier, gay and bisexual men whom the Kennedy-Johnson Administration sought to deport as statutory psychopaths. Based on newer and more reliable medical research, counsel maintained that lesbigay people generally were no more mentally defective than straight people. The Ninth Circuit's opinion in Fleuti was the rare decision that recognized some part of this new rhetoric of recognition. Kameny and Boutilier lost their cases, and Manual Enterprises and Fleuti won theirs only on legal technicalities.

Likewise, MSW sponsored challenges to the federal civil service exclusion through the 1960 s, and sometimes its attorneys were successful - but always under cover of the procedural and nonarbitrariness features of the Due Process Clause. ${ }^{551}$ Chief Judge David Bazelon of the D.C. Circuit ruled in Norton v. Macy ${ }^{552}$ that it was a violation of due process guarantees for the CSC to bar gay people from employment without a demonstrated "nexus" between their sexual orientation or activities and the legitimate requirements of their jobs. Authored by a judge with deep understanding of the medical literature debunking anti-homosexual stereotypes, Norton was a breakthrough precedent, in part because it was handed down simultaneously with the Stonewall riots, after which thousands of lesbigay people streamed out of their closets and protested their various state exclusions. ${ }^{553}$

549. Brief of Appellant at 23, Manual Enters. v. Day, 370 U.S. 478 (1962) (1961 Term, No. 123).

550. Id.

551. For the few successful challenges, see Dew v. Halaby, 317 F.2d 582 (D.C. Cir. 1963), cert. granted, 376 U.S. 904 (1964) (after certoriari granted, government agreed to reinstate married civil servant who had committed "homosexual acts" in his youth); and Scott v. Macy, 349 F.2d 182 (D.C. Cir. 1965), 402 F.2d 644 (D.C. Cir. 1968) (overturning CSC's discharge of gay man). Outside of the D.C. Circuit, such challenges generally failed in the late 1960s. See, e.g., Anonymous v. Macy, 398 F.2d 317 (5th Cir. 1969); Taylor v. United States Civil Serv. Comm'n, 374 F.2d 466 (9th Cir. 1967).

552. 417 F.2d 1161 (D.C. Cir. 1969); see Rhonda R. Rivera, Our Straight-Laced Judges: The Legal Position of Homosexual Persons in the United States, 30 HASTINGS L.J. 799 (1979) [hereinafter Rivera, Our Straight-Laced Judges] (discussing Norton and its aftermath).

553. The Stonewall riots were June 26-28, 1969; Norton was handed down July 1, 1969. Until a month before he issued Norton, Bazelon served on a task force studying homosexu- 
Within a year of Stonewall, the ACLU's Norman Dorsen and Charles Lister revived Kameny's equal protection arguments in a petition for the Supreme Court to review the civil service exclusion. They maintained that gay people are good citizens, homosexuality is an acceptable variation from the norm, and antigay employment discrimination is "odious," unjust and, for all of these reasons, contrary to the equal protection component of the Fifth Amendment. ${ }^{554}$ Although the Supreme Court continued to ignore these arguments, they were starting to have bite with more lower courts. Decisions by federal judges in the District of Columbia and California, where lesbigays were politically mobilized, ruled civil service discriminations unconstitutional, and the CSC formally abandoned its policy in 1973-74. ${ }^{555}$ The Supreme Court even granted certiorari for a petition by a cross-dressing gay man who had (before the CSC policy shift) been discharged by the EEOC for "flaunting" his sexual orientation. ${ }^{556}$

Many municipalities and states followed the CSC's lead, but other government employers, including the federal armed forces, continued to exclude and discharge gay people because of their sexual orientation. Gone were the days when outed "homosexuals" passively accepted their fates, however; a substantial number of those discharged brought lawsuits as openly lesbigay persons. Most of the lawsuits were unsuccessful in the $1970 \mathrm{~s},{ }^{557}$ but some judges were willing to overturn discharges because they were not accompanied by any statement of reasons $^{558}$ or because there was no nexus between the agreed-upon

ality for the National Institute of Mental Health. Rivera, Our Straight-Laced Judges, supra note 552 , at 1036 n.107.

554. Brief for Petitioners at 6-9, Schlegel v. United States, 397 U.S. 1039 (1970) (1969 Term, No. 1257), denying cert. to 416 F.2d 1372 (Ct. Cl. 1969); Brief for Petitioner at 5, Adams v. Laird, 397 U.S. 1039 (1970), denying cert. to 420 F.2d 230 (D.C. Cir. 1969), (1969 Term, No. 1258).

555. For an account of the cases and of the decline and fall of CSC's exclusion, see William N. Eskridge, Jr., Challenging the Apartheid of the Closet: Establishing Conditions for Lesbian and Gay Intimacy, Nomos, and Citizenship, 1961-1981, 25 HOFSTRA L. REV. 817, 911-18 (1997) [hereinafter Eskridge, Establishing Conditions]. Executive Order No. 13,087, 63 Fed. Reg. 30,097 (May 28, 1998), prohibited employment discrimination on the basis of sexual orientation by the federal government outside the armed forces.

556. Singer v. United States Civil Serv. Comm'n, 429 U.S. 1034 (1977), granting cert. to 530 F.2d 247 (9th Cir. 1976); see Rhonda R. Rivera, QueerLaw: Sexual Orientation Law in the Mid-Eighties (Pt. 1), 10 U. DAYTON L. REV. 459, 485 (1985) (federal government reinstated Singer after certiorari was granted, and so the case was never heard by the Court).

557. See, e.g., McConnell v. Anderson, 451 F.2d 193 (8th Cir. 1971), rev'g 316 F. Supp. 809 (D. Minn. 1970); see Rivera, Our Straight-Laced Judges, supra note 552, at 1043-47 (surveying the state employment cases), $i d$. at 1078-92 (surveying cases where public school teachers were discharged on grounds of homosexuality).

558. See, e.g., Matlovich v. Sec'y of the Air Force, 591 F.2d 852, 860 (D.C. Cir. 1976); see Mike HiPPLER, MATLOVICH: THE GOOD SOLDIER (1989). 
reasons for discharge and legitimate job requirements. ${ }^{559}$ By the late 1970 s, counsel for those discharged were no longer willing to rest their cases on due process arguments alone, however. Like Kameny, they maintained that it was a violation of equal protection for gay people to be treated any differently from straight people. Their arguments met with a variety of thoughtful responses, especially in the military exclusion cases. In the leading case, Beller v. Middendorf, ${ }^{560}$ Judge Anthony Kennedy upheld the armed forces bar largely because of the judiciary's long tradition of near-absolute deference to military judgments; because the Navy's reasons were defensibly pragmatic concerns with unit cohesion, the chain of command, and recruitment, its exclusionary policy was constitutionally permissible. ${ }^{561}$ The opinion, however, explicitly recognized that discriminatory treatment of gay people in other institutional contexts could represent valid privacy and equal protection claims. ${ }^{562}$

In a civil employment case, the California Supreme Court gave a stronger endorsement to gay people's politics of recognition, but under free speech auspices. In Gay Law Students Association v. Pacific Telephone \& Telegraph Co. ${ }^{563}$ the court ruled that harassment or discharge of openly gay employees violated a statutory bar to discrimination on the basis of "political activities or affiliations." Because "the struggle of the homosexual community for equal rights, particularly in the field of employment, must be recognized as a political activity," and because "com[ing] out of the closet" and "acknowledg[ing] their sexual preferences" were essential to that politics as understood by gay people, efforts to discourage or penalize such employees and press them back into their closets was within the bar to political activity discrimination. ${ }^{564}$

I start with the employment cases because they dramatically illustrate the new kinds of constitutional arguments, but lesbigay people's new politics of recognition also triggered important public discourses in connection with lesbian and gay associations, criminal law and enforcement, and family law. If lesbigay groups and organizations could be counted on a few hands in 1961, they numbered in the hundreds within a few years of Stonewall. The NAACP cases insulated these associations from direct state persecution or harassment, but state insti-

559. See, e.g., Bd. of Educ. v. Jack M., 566 P.2d 602 (Cal. 1977); Morrison v. State Bd. of Educ., 461 P.2d 375 (Cal. 1969).

560. 632 F.2d 788 (9th Cir. 1980) (reversing Saal v. Middendorf, 427 F. Supp. 192 (N.D. Cal. 1977) and abrogating Martinez v. Brown, 449 F. Supp. 207 (N.D. Cal. 1978)).

561. See id. at $810-12$.

562. See id. at 809-10 (right of privacy in some contexts); id. at 812 (equal protection).

563. 595 P.2d 592 (Cal. 1979).

564. Id. at 610 . 
tutions were reluctant to provide any kind of sanction to them. ${ }^{565}$ After the 1960 s, this was no longer tolerable in jurisdictions where lesbigay people were politically mobilized. For example, the Lambda Legal Defense and Education Fund, Inc. was formed "to promote the availability of legal services to homosexuals by encouraging and attracting homosexuals into the legal profession; to disseminate to homosexuals general information concerning their rights and obligations; and to render technical assistance to any legal services corporation or agency in regard to legal issues affecting homosexuals." New York's Appellate Division balked at approving Lambda as an authorized legal group, and Lambda's first legal victory came when the Court of Appeals vacated the original decision and the Division grudgingly approved its application. ${ }^{56}$ Other lesbian and gay groups also sued, usually with success, to require state officials to register them on equal terms with other associations. ${ }^{567}$ After several years of resistance, the Internal Revenue Service in 1977 agreed to recognize tax exemptions for gay groups formed for educational or charitable purposes. ${ }^{568}$

Many right of association cases arising from the new politics of recognition involved public universities. The leading case was Gay Students Organization v. Bonner. ${ }^{569}$ The University of New Hampshire recognized the Gay Students Organization ("GSO") but sought to limit GSO's social and political activism that stirred enormous publicity and political trouble for the administration. Judge Coffin's opinion ruled that the university as a public forum could not discriminate against gay people's politics of recognition, which included social events and plays as well as more conventional educational activities. ${ }^{570}$

565. E.g., Eskridge, Establishing Conditions, supra note 555, at 876-77 (congressional investigation into D.C. registration of MSW as a "charitable organization). The NAACP cases are discussed in Sections I.A.3 and II.F.1.

566. See In re Thom, 301 N.E.2d 542, 543 (N.Y. 1973), on remand 350 N.Y.S.2d 1 (App. Div. 1973). The Court of Appeals' opinion quoted Lambda's statement of purpose. 301 N.E. $2 \mathrm{~d}$ at 543 . The court chose to strike part of the statement of purpose on remand, deeming it to fall outside the scope of the law authorizing legal assistance corporations. 350 N.Y.S.2d 2 .

567. Compare GAA v. Lomenzo, 293 N.E.2d 255 (N.Y. 1973) (requiring state officials to register gay rights group), with Grant v. Brown, 313 N.E.2d 847 (Ohio 1974) (allowing state officials to refuse registration, on "no promo homo" grounds).

568. IRS Reverses Policy on Tax Exemptions, ADVOCATE, Oct. 5, 1977, at 11 (IRS announcement); Rev. Rul. 78-305, 1978-2 C.B. 172 (formal rule).

569. 509 F.2d 652 (1st Cir. 1974); cf. Rivera, Our Straight-Laced Judges, supra note 552, at 1144 (describing an unreported 1971 California Superior Court decision, Associated Students of Sacramento State College v. Butz, Civ. No. 200795, which required a state college to recognize a gay student group on the ground that the First Amendment bars public forums from discriminating on the basis of the content of the speech or association of petitioners).

570. On the other hand, the judge conceded the university ample room for regulation of "overt sexual behavior, short of criminal activity, which may offend the community's sense of propriety." Bonner, 509 F.2d at 663 . 
Judges all over the country followed Bonner to require fair access by gay student groups to state collegiate public forums. ${ }^{571}$

After a substantial number of lesbigay people came out of their closets, the operation of the criminal justice system in big cities changed, almost overnight, with regard to gay and bisexual men in particular. Most changes were effectuated through the political process, as police departments were pressured into reducing resources devoted to victimless crime enforcement and as legislatures were persuaded to repeal their consensual sodomy laws. ${ }^{572}$ But constitutional law also played an important role, and a different role than it played before the 1960s. During the earlier period of the politics of protection, gay people relied on after-the-fact retail arguments (if they dared resist at all): this particular arrest was tainted with entrapment, denial of counsel, a coerced confession, and so forth. Once gay people mobilized, and gained institutional allies such as the ACLU (in the 1960s) and Lambda (1970s), they made sweeping wholesale arguments: the jurisdiction's cross-dressing, sexual solicitation, lewd conduct, or sodomy law cannot be applied to any such defendants because it is unconstitutional. The reasons these statutes were said to be unconstitutional included not just the traditional due process problem of vagueness and lack of notice, but also newer problems raised by the right to privacy (Griswold), the First Amendment (Stanley), and even the Equal Protection Clause (Kameny).

For one important example, when North Carolina entrapped Eugene Enslin into a violation of its consensual sodomy law, the ACLU took up his defense. As foundation for its argument at trial that the statute was unconstitutional, ACLU attorney Marilyn Haft presented evidence that the conduct criminalized (oral and anal sex) is performed by and gives great pleasure to a majority of Americans, without any harm to them or to third parties, and that the people most stigmatized by the statute, gay people, are psychologically normal, non-predatory citizens. ${ }^{573}$ The ACLU appealed Enslin's conviction all the way to the Supreme Court, where it was joined by Lambda and the National Gay Task Force. No one argued that the law was unclear, nor

571. See, e.g., Gay Lib v. Univ. of Missouri, 558 F.2d 848 (8th Cir. 1977); Gay Alliance of Students v. Matthews, 544 F.2d 162 (4th Cir. 1976). For a recent example, see Gay Lesbian Bisexual Alliance v. Pryor, 110 F.3d 1543 (11th Cir. 1997).

572. See Eskridge, Establishing Conditions, supra note 555, at 836-42 (gay political pressure leading to milder police practices in various cities); $i d$. at 842-63 (gay political pressure and litigation leading to repeal, invalidation, or narrow construction of sodomy, lewdness, and cross-dressing laws); Steven A. Rosen, Police Harassment of Homosexual Women and Men in New York City 1960-1980, 12 COLUM. HUM. RTS. L. REV. 159 (1980-81) (providing a detailed account of milder application of criminal laws against gay people in New York City).

573. Petition for a Writ of Certiorari at 6-9, Enslin v. North Carolina, 425 U.S. 903 (1976) (No. 75-897) (describing defendant's case at trial). 
did the petitions merely plead for the state to leave gay people alone. Instead, the petitioners maintained that sodomy laws were the legal authorization for an array of public and private practices punishing lesbigay people unfairly - employment discrimination, police harassment, exclusion from the armed services, loss of children, and the closet itself. ${ }^{574}$ As Lambda put it, "just as the elimination of legal segregation and miscegenation laws [was] a necessary first step to the elimination of race prejudice, so the elimination of the sodomy laws is the essential first step to the elimination of unwarranted prejudice against gay people." 575 Although the Justices declined to address Haft's arguments, they had receptive audiences in other judiciaries. New York's Court of Appeals invalidated that state's consensual sodomy law for these kinds of reasons in People $v$. Onofre ${ }^{576}$ Indeed, the state judiciaries of New York, California, New Jersey, Ohio, and Massachusetts narrowly construed or invalidated laws in those jurisdictions that had been deployed by the police to terrorize lesbigay and transgendered people. ${ }^{577}$

The most radical manifestation of lesbigay people's politics of recognition was in the arena of family law. Not only were lesbians and gay men insisting on their rights to come out of their closets in the workplace and in public culture, but they asserted their moral and constitutional rights to have the state recognize and protect their families. The most sensational cases were the same-sex marriage ones, and the first of those was Baker $v$. Nelson. ${ }^{578}$ After the Minnesota Attorney General and Supreme Court denied a male couple's right to a marriage license, Michael Wetherbee of the local ACLU chapter filed an appeal with the U.S. Supreme Court. "At first, the question and the proposed relationship may well appear bizarre - especially to heterosexuals," but that first impulse "provides us with some measure

574. Id. at 11-17; Brief of Amicus Curiae Lambda Legal Defense and Education Fund, Inc. at 7-12, Enslin (No. 75-897). The ACLU and Lambda made similar arguments in their briefs seeking rehearing of the Court's refusal to grant review, and there they were joined by the Brief of Amicus Curiae National Gay Task Force in Support of Petition for Rehearing, Ensiin (No. 75-897).

575. Brief of Amicus Curiae Lambda Legal Defense and Education Fund, Inc. at 11-12, Enslin (No. 75-897).

576. 415 N.E.2d 936 (N.Y. 1980), cert. denied, 451 U.S. 987 (1981).

577. See, e.g., Pryor v. Mun. Court, 599 P.2d 636 (Cal. 1979) (narrowly construing "vaglewd" law used to entrap gay men) (discussed in greater detail in Section II.A.3); People v. Uplinger, 447 N.E.2d 62 (N.Y. 1983) (invalidating on privacy grounds the state law barring loitering for the purpose of solicitation of "deviate sexual intercourse"); City of Columbus v. Rogers, 324 N.E.2d 563 (Ohio 1975) (invalidating on vagueness grounds a municipal crossdressing ordinance). For a detailed discussion of cases from a variety of jurisdictions, see Eskridge, Establishing Conditions, supra note 555, at 842-52 (privacy challenges) and 852-63 (vagueness challenges).

578. 191 N.W.2d 185 (Minn. 1971), appeal dismissed, 409 U.S. 810 (1972). 
of the continuing impact on our society of prejudice against nonheterosexuals." Indeed, Wetherbee maintained, "the relationship contemplated is neither grotesque nor uncommon." 579 He set forth a brief case for the descriptive proposition that sexual variation is benign and homosexuality normal. Prescriptively, he argued that marriage bars should be subjected to heightened scrutiny for any of three reasons. First, such bars deny lesbian and gay couples their fundamental right to marry that had been recognized in Griswold (for straight couples) and Loving (different-race couples). ${ }^{580}$ Second, the marriage bar also denies such couples the important property and economic rights that accompany spousehood as a matter of law. ${ }^{581}$ Third, the state's discrimination was one "based on gender." 582 Whatever the basis for heightened scrutiny, the state marriage bar could not be sufficiently justified. The state's argument that marriage had always been different-sex (the reason accepted by the courts below) begged the normative question, and the state's association of marriage with children did not justify treating childless gay couples differently from childless straight ones, as the statute did. By a unanimous vote, the Supreme Court dismissed the appeal in Baker, but all the key arguments for invalidating same-sex marriage bars were suggested in that case. $^{583}$

At the same time same-sex couples were going to court seeking marriage licenses from the state, lesbigays formerly married to persons of the opposite sex were being dragged into court by their former spouses seeking to deprive them of all contact with their children. Lesbian and gay parents who chose to fight for their children, as many did, turned to studies showing that their orientation had no bearing on their ability to be good parents. Lesbigay parents and their lawyers ultimately revolutionized custody law, as most states abandoned per se rules against lesbigay custody of their own children and adopted the

579. Jurisdictional Statement at 8-9, Baker v. Nelson, 409 U.S. 810 (1972) (No. 71-1027).

580. See id. at 11.

581. See id. at 11-12.

582. See id. at 16-18. The brief did not flesh out this argument, as the Court had just handed down its first sex discrimination decision, Reed v. Reed, 404 U.S. 71 (1971), but it appears that the argument was inspired by the miscegenation analogy: just as the bar to different-race marriage was treated as race discrimination in Loving, so the bar to same-sex marriage should be treated as sex discrimination. This precise argument was made and rejected in Singer v. Hara, 522 P.2d 1187 (Wash. App.), reh'g denied, 84 Wash.2d 1008 (1974) (interpreting the state ERA as not requiring state recognition of same-sex marriages).

583. 409 U.S. 810 (1972); see Docket Sheet for Baker, in Brennan Papers, supra note 129 , Box I:281, Folder 1 (revealing that all nine Justices voted to dismiss the appeal). For discussion of the other same-sex marriage cases of the 1970s and 1980s, see WILLIAM N. ESKRIDGE, JR., THE CASE FOR SAME-SEX MARRIAGE $52-57$ (1996); $c f$. id. at 232-33 nn.2324, 248-49 n.18 (listing the attorney general and judicial decisions). 
best interests of the child standard. ${ }^{584}$ Nonetheless, most openly gay or lesbian parents lost their legal battles in the 1970s. Even when they were successful in retaining custody or visitation rights, courts often imposed burdens and conditions on them that would never have been contemplated for straight parents. ${ }^{585}$

A striking feature of the foregoing discussion of gay people's politics of recognition in this formative period is that the Burger Court as a group were unwilling to listen or respond to any of it. In every case presented for its review between 1969 and 1986, the Court either denied certiorari (as in Enslin), granted review without reaching the merits ${ }^{586}$ or affirmed an antigay decision without briefing or argument (as in Baker). Sometimes these avoidances provoked dissents. In Doe v. Commonwealth's Attorney, ${ }^{587}$ the Court summarily affirmed a lower court decision upholding Virginia's consensual sodomy law against privacy, equal protection, and First Amendment attack. Justices Brennan, Marshall, and Stevens dissented on the ground that the important privacy issues should have been briefed and argued. ${ }^{588}$ The Court denied certiorari in Ratchford v. Gay Lib ${ }^{589}$ thereby leaving in effect a lower court decision requiring a state university to recognize and fund a gay rights group. Justice Rehnquist wrote a passionate dissent, arguing that the lower court was requiring the state to tolerate moral contagion. He rejected the claim that the students were merely engaged in political and educational activities and insisted that "the question is more akin to whether those suffering from measles [i.e., homosexuality] have a constitutional right, in violation of quarantine regulations [i.e., the state sodomy law], to associate together and with others [i.e., vulnerable youth] who do not presently have measles."

Finally, the Court denied review to Rowland v. Mad River Local School District ${ }^{591}$ which had upheld the discharge of a bisexual high

584. Excellent reviews of this litigation are found in Nan D. Hunter \& Nancy Polikoff, Custody Rights of Lesbian Mothers: Legal Theory and Litigation Strategy, 25 BUFF. L. REV. 691 (1976); and Rivera, Our Straight-Laced Judges, supra note 552, at 1102-23.

585. See, e.g., Schuster v. Schuster, 585 P.2d 130 (Wash. 1978) (en banc).

586. People v. Uplinger, 447 N.E.2d 62 (N.Y. 1983), cert. dismissed as improvidently granted, 467 U.S. 246 (1984). The decision followed and applied the Court of Appeals' prior decision in Onofre.

587. 425 U.S. 901 (1976), summarily aff'g 403 F.Supp. 1199 (E.D. Va. 1975) (three-judge court). The Court's order in Doe was issued the same day the Court denied certiorari in Enslin.

588. Id. (Brennan, Marshall, and Stevens, JJ. would have noted probable jurisdiction).

589. 434 U.S. 1080 (1978) denying cert. to Gay Lib v. University of Missouri, 558 F.2d 848 (8th Cir. 1977).

590. Id. at 1084 (Rehnquist, J., joined by Blackmun, J., dissenting from the denial of certoriari).

591. 730 F.2d 444 (6th Cir. 1984), cert. denied, 470 U.S. 1009 (1985). 
school guidance counselor against First Amendment and equal protection attack. Justice Brennan, joined by Justice Marshall, vigorously dissented and laid out substantive reasons for reversing the lower court. The dissenters maintained that sexual orientation - like sex, illegitimacy, and race - ought to be a suspect classification, because the group stigmatized by the classification has been the object of hostile state action reflecting prejudice rather than rationality and because that group has been relatively powerless in the political process. ${ }^{592}$ Brennan's statement was the most complete analysis, at the Supreme Court level, of the level of scrutiny owed to sexual orientation classifications. (Note some parallels to Brennan's plurality opinion in Frontiero.) Even if sexual orientation were not a suspect classification per se, Brennan argued that the state bore a high burden of justification when it denies a minority group public rights, including employment opportunities, because of either their private choices and conduct or their "nondisruptive expression of homosexual preference." 593

\section{The Ongoing Politics of Recognition and Remediation and the Politics of Preservation, 1981-Present}

Even the limited success of gay people's politics of recognition in the late 1970s alarmed traditionalists and called forth a politics of preservation. What I call the "traditional family values" ("TFV") movement emerged as a well-organized countermovement between 1976 and $1981 .^{594}$ It has flourished since then, even as more Americans have come out as lesbian or gay or bisexual and as litigating organizations have pursued gay rights systematically. ${ }^{595}$ Like the anti-civil rights

592. Rowland, 470 U.S. at 1014 (Brennan, J., dissenting from the denial of certiorari); see also MURDOCH \& PRICE, supra note 510, at 241-51 (giving a moving account of Brennan's gay rights dissent).

593. Rowland, 470 U.S. at 1015-16 (Brennan, J., dissenting from the denial of certiorari).

594. Key moments in the emergence of the TFV countermovement were the debate over sodomy reform and same-sex marriage in California in 1976-77; Anita Bryant's "Save the Children" campaign to override Dade County's antidiscrimination law in 1977, and subsequent successful initiatives revoking progay laws in St. Paul, Witchita, and other cities in 1978 and 1979; California's unsuccessful Briggs Initiative in 1978, whose proponents sought to bar from public schoolteaching any person who "advocated" homosexuality in any way; and the Moral Majority's successful campaign to persuade Congress to override the District of Columbia's attempted sodomy law repeal in 1981. See generally CHRISTOPHER BULL \& John Gallagher, Perfect EnEmies: The Religious Right, THE GAy MOVement, AND THE POLITICS OF THE 1990S (1996); DIDI HERMAN, THE ANTIGAY AgENDA: ORTHODOX VISION AND THE CHRISTIAN RIGHT (1997).

595. Lambda and the ACLU (which formally established a Lesbian \& Gay Rights Project headed by Nan Hunter) remained the leading litigation groups. They have been joined by Gay and Lesbian Advocates and Defenders in Boston and other regional litigation groups. 
and pro-life countermovements with which it was linked, the TFV countermovement has had natural law and pragmatic faces. Natural law traditionalists maintain that sexual variation is malignant, for religious ("abomination") or medical (AIDS) or mental heath (psychopathic) reasons. ${ }^{596}$ Therefore, it would be a catastrophe for the state to provide any "special rights" to gay people or not to criminalize sodomy. Pragmatic traditionalists, in contrast, concede that there is some tolerable variation in sexuality. They are willing to abandon sodomy laws, for practical reasons, and focus on positive projects that would be threatened by too many "special rights" for gay people. ${ }^{597}$ Thus, the state should tolerate gay people but should not promote homosexuality. The "no promo homo" arguments of the last several decades are the rhetorical means by which TFV extremists and moderates can work together and even attract ordinary Americans to their point of view. ${ }^{598}$ Again like prior countermovements, TFV people from both horizons espouse a shared constitutional philosophy of states' rights, institutional deference, and individual liberties.

American law in the 1980 s and 1990 s was a battleground between an increasingly vigorous lesbigay people's politics of recognition/remediation and an equally vigorous politics of preservation. The consequent legal equilibrium varied significantly by state or region: in gay-friendly states like California, New York, and Vermont, lesbigay people now enjoy normal personal and economic liberties and increasing state protection against private violence and discrimination; in noncommittal states like New Mexico and Pennsylvania, lesbigay people are not much harassed or arrested, but neither are they afforded normal protections by the state against private violence and discrimination; and in states in the South, lesbigay people are still treated like presumptive criminals. ${ }^{599}$ The TFV strategy within states has been to localize progay measures to the urban areas where lesbigay people are concentrated; in the country at large, the strategy has been to protect states like Mississippi and Texas from the constitutionalization of policies followed in New York and California. TFV

596. See, e.g., Anita Bryant, The AnITA Bryant Story: The Survival of OUR NATION'S FAMILIES AND THE THREAT OF MILITANT HOMOSEXUALITY (1977) (religious and moral); JosepH Nicolosi, ReParative Therapy of Male Homosexuality: A NEW CliNiCAL APPROACH (1991) (mental health).

597. See e.g., StePHEN Bransford, Gay Politics vs. Colorado and AMERICA: THE INSIDE STORY OF AMENDMENT 2, 36-40 (1994) (supporters of Amendment 2 chose a pragmatic over a natural law approach to that antigay initiative).

598. See William N. Eskridge, Jr., No Promo Homo: The Sedimentation of Antigay Discourse and the Channeling Effect of Judicial Review, 75 N.Y.U. L. REV. 1327, 1338-46 (2000) [hereinafter Eskridge, No Promo Homo]. $362-71$.

599. For antigay laws, state-by-state, see ESKRIDGE, GAYLAW, supra note 14, app. B3 at 
people have also had confidence that their position is one that ordinary folks would prefer to that of elitist judges - so they prefer that decisions be made by legislation and popular referenda rather than through judicial review and constitutional discourse. ${ }^{600}$

Since 1981, therefore, American politics of sexuality has been caught up in this pas de deux between gay people's politics of recognition and TFV people's politics of preservation. Because both sides have constitutionalized their discourse, the courts have been drawn into the culture clash - including the once comically squeamish U.S. Supreme Court. To the extent there has been a national consensus about issues of sexuality it has been the edgy ambivalent tolerance of "no promo homo": states are not allowed to hurt lesbigay people and are required to provide them minimal protections of law, but are not required to "promote" homosexuality in affirmative ways and indeed are debarred from forcing private groups to accept lesbigay people if they feel that acceptance is tantamount to "endorsing" homosexuality.

a. Sodomy Laws and the Military Exclusion. No issue has set the gay rights movement apart from the civil rights and women's rights movements more than the association of homosexual status with homosexual conduct. That many Americans claim to be disgusted by the latter makes it harder for gay people to claim protection because of the former. ${ }^{601}$ It is for this reason that lesbigay legal groups have since the 1960 s made sodomy law repeal or invalidation their central goal. By 1986, when the Burger Court finally addressed the privacy argument against consensual sodomy laws in Bowers v. Hardwick, ${ }^{602}$ half the states had repealed their laws, either judicially or (for most states) legislatively. As Professor Larry Tribe realized, there was no Court majority for a "gay rights" argument, and so his brief for the challenger pushed homosexuality into a legal closet and emphasized the abuse of state power represented by the gendarmerie's charge into Michael Hardwick's bedroom. No one else saw the case his way, though. Homosexuality was front and center in the remainder of the briefs. The American Psychological Association's brief presented the benign sexual variation notion that the conduct criminalized in

600. For the most part, they have been right about that, as antigay initiatives have shown an astounding success rate. See Barbara S. Gamble, Putting Civil Rights to a Popular Vote, 41 AM. J. POL. SCI. 245, 251, 258 (1997). By my informal count, however, more than half of the antigay referenda after 1997 have failed. See infra note 1535.

601. For insightful discussions of this phenomenon, see Anne B. Goldstein, Comment, History, Homosexuality, and Political Values: Searching for the Hidden Determinants of Bowers v. Hardwick, 97 YALE L.J. 1073 (1988) [hereinafter Goldstein, History, Homosexuality]; Janet E. Halley, Reasoning About Sodomy: Act and Identity in and after Bowers v. Hardwick, 79 VA. L. REV. 1721 (1993); Jed Rubenfeld, The Right of Privacy, 102 HARV. L. REV. 737, 777-800 (1989); and Michael Sandel, Moral Argument and Liberal Toleration: Abortion and Homosexuality, 77 CAL. L. REV. 521 (1989).

602. 478 U.S. 186 (1986) (discussed also in Section II.B). 
Georgia is in no way pathological and, indeed, is important to the psychological health of individuals and to their intimate relationships, whether homosexual or heterosexual..$^{603}$ The state responded that the statute reflected the moral judgments of the people of Georgia, and the Court could not legitimately interfere with those judgments unless required by constitutional text or well-established precedent.

Justice White's perfunctory opinion for the Court agreed with the state, concluding that it was illegitimate for the unelected Justices to overturn the state legislature's moral judgment that sodomy is wrong, without a firmer basis in constitutional text or tradition. ${ }^{604}$ Even within that framework, however, White's obsessive focus on "homosexual sodomy," notwithstanding the statute's inclusion of sodomy of all kinds, exposed the Court to criticism that it was not treating gay people impartially. ${ }^{605}$ Four dissenting Justices not only questioned the Court's analysis, but recognized the link between lesbigay people's equal citizenship and a constitutional recognition of benign sexual variation: $:^{606}$

Only the most willful blindness could obscure the fact that sexual intimacy is "a sensitive key relationship of human existence, central to family life, community welfare, and the development of human personality." The fact that individuals define themselves in a significant way through their intimate sexual relationships with others suggests, in a Nation as diverse as ours, that there may be many "right" ways of conducting those relationships, and that much of the richness of a relationship will come from the freedom an individual has to choose the form and nature of these intensely personal bonds.

The dissenters also contrasted the Court's passivity in Hardwick with its productive activism in Brown, Loving, and Roe, all of which have

603. See Brief of Amici Curiae American Psychological Association and American Public Health Association in Support of Respondents, passim, Hardwick (No. 85-140); see also Brief of Amicus Curiae for Lesbian Rights Project [and other feminist groups], passim, Hardwick (No. 85-140) (similar argument, plus sodomy laws contribute to rampant discrimination against lesbigay people in particular). These kinds of briefs, routinely filed in gay rights cases, are called "Homo 101 briefs" because they lay out the established scientific facts of (gay) life to presumptively ignorant judges.

604. Hardwick, 478 U.S. at 194-95; see id. at 191-94 (asserting that the argument that "homosexual sodomy" is protected by the nation's libertarian tradition is, "at best, facetious").

605. Compare id. at 190, 191, 192, 196 (limiting case to "homosexual sodomy"), and id. at 196-97 (Burger, C.J., concurring) (similar), with id. at 199-200 (Blackmun, J., dissenting) (arguing that it is morally arbitrary for the Court to insist that only "homosexual sodomy" is at stake, when the statute covers all kinds of sodomy), and id. at 215-16 (Stevens, J., dissenting) (noting that state legislature deliberately expanded its sodomy law to include all different-sex sodomy).

606. Id. at 205 (Blackmun, J., joined by Brennan, Marshall, and Stevens, JJ., dissenting) (quoting Paris Adult Theatre I v. Slaton, 413 U.S. 49, 63 (1973) and citing Kenneth Karst, The Freedom of Intimate Association, 89 YALE L.J. 624, 637 (1980)). 
been cogently criticized for expanding constitutional freedoms beyond the boundaries suggested by constitutional text and original intent. ${ }^{607}$

The Court's 5-4 decision upholding Georgia's law brought upon the Court the greatest criticism I have seen for a decision upholding rather than striking down a law. ${ }^{608}$ Legal junkies continue to be fascinated by new revelations about the many corrupt features of the case, such as Attorney General Bowers' longtime adulterous (and allegedly sodomitic) affair during the case. ${ }^{609}$ In a twisted way, Hardwick was (in part) a boon to lesbigay rights as a social movement, for the Court's openly antigay opinion not only reinforced lesbigays as a "marked" minority group, but also rallied lesbigay attorneys out of their closets in record numbers and attracted moderate allies. Movement lawyers brought fresh challenges under state constitutions and have prevailed in most of the cases. ${ }^{610}$ Social norms have decisively moved away from the Supreme Court's assumptions: conservatives and traditionalists as well as liberals and civil rights advocates have joined in a public consensus that the state should not make consensual sodomy a crime. On the other hand, there is no consensus for the proposition that sodomy is unproblematic - and in one area of law, sodomy remains the key to a strong antigay policy, the military exclusion.

Surprisingly, the stream of cases appealing the exclusion of lesbigay people from the armed forces continued after Hardwick. Indeed, the Ninth Circuit fiercely debated the issue in Watkins $v$. United States Army. ${ }^{611}$ Judge William Norris' panel opinion ruled that the army's exclusion of "homosexuals" (defined as people who "desire[] bodily contact between persons of the same sex") was a status-based discrimina-

607. Id. at 210-11 n.5 (Blackmun, J., dissenting).

608. Critiques from different points of view include ESKRIDGE, GAYLAW, supra note 14, ch. 4 (precedent and gaylegal history); CHARLES FRIED, ORDER AND LAW - ARGUING THE REAGAN REVOlution $81-84$ (1991) (precedent); RiCHARD A. POSNER, SEX AND REASON 341-50 (1991) (libertarian philosophy); Goldstein, History, Homosexuality, supra note 601 (history); Sylvia Law, Homosexuality and the Social Meaning of Gender, 1988 WIS. L. REV. 187 (feminist premises and history); and Frank I. Michelman, Law's Republic, 97 YALE L.J. 1493 (1987) (republican philosophy). There is no major law review article or legal book defending Hardwick, a notable contrast to other controversial Supreme Court opinions, such as Roe v. Wade or even Brown.

609. See MURDOCH \& PRICE, supra note 510, at 493-94.

610. For decisions striking down consensual sodomy laws under state constitutions, see Powell v. State, 510 S.E.2d 18 (Ga. 1998) (the Hardwick law); Commonwealth v. Wasson, 842 S.W.2d 487 (Ky. 1992); State v. Cogshell, 997 S.W.2d 534 (Mo. App. 1999); Gryczan v. Montana, 942 P.2d 112 (Mont. 1997); and Campbell v. Sundquist, 926 S.W.2d 250 (Tenn. App. 1996) (appeal denied). For opinions upholding a law against state constitutional challenge, see State v. Smith, 766 So.2d 501 (La. 2000), and Lawrence v. State, 41 S.W.3d 349 (Tex. 2001) (petition for certiorari pending).

611. 847 F.2d 1329 (9th Cir. 1988), vacated en banc, 875 F.2d 699 (9th Cir. 1989) (discussed in Section II.C.1.f). 
tion subject to strict scrutiny. ${ }^{612}$ In dissent, Judge Stephen Reinhardt read Hardwick to condone "anti-homosexual animus in the actions of the government," and to allow the state to discriminate against that class of people who are predisposed to commit criminalizable sodomy. ${ }^{613}$ There were analytical problems with both stances: as Norris argued, Hardwick was concerned only with homosexual conduct and, even in that sphere, did not reach equal protection issues - but because homosexual status is defined by the desire and the proclivity to engage in proscribable conduct, Hardwick was not irrelevant to the equal protection issue, Reinhardt's point. ${ }^{614}$ Ultimately, the Ninth Circuit, en banc, vacated the Norris opinion and judgment but ruled that the army was debarred on estoppel grounds from expelling Perry Watkins. ${ }^{615}$

The 1993 debate over the president's proposed executive order ending the bar to gays in the military echoed the Norris-Reinhardt debate, with added twists. Critics of the lesbigay exclusion emphasized the status denigration, reminiscent of the military's exclusion and later segregation of blacks and women; like these other minorities, lesbigay people would not enjoy the full status of citizens until they could openly serve their country as soldiers. ${ }^{616}$ Supporters of the exclusion were insulted by the parallel to discredited race and gender exclusions, because the antigay policy was grounded upon conduct not status. Unlike people of color, who were victims of prejudiced attitudes, gay people (this argument went) were themselves responsible for lowering morale and unit cohesion because of their disruptive behavior. ${ }^{617} \mathrm{Al}$ though this kind of preservationist argument has been rejected in most other industrial countries, it prevailed in the United States in 1993. The result was a statutory exclusion of anyone who either engaged in "homosexual acts" or had a "propensity" to do so, ${ }^{618}$ assertedly (but

612. Watkins, 847 F.2d at 1336.

613. Id. at 1355-58 (Reinhardt, J., dissenting). But see id. at 1339-42 (Norris, J., distinguishing Hardwick).

614. See Nan D. Hunter, Life After Hardwick, 27 HaRV. C.R.-C.L. L. REV. 531 (1992).

615. Watkins, 875 F.2d 699 (9th Cir. 1989) (en banc).

616. See Kenneth L. Karst, The Pursuit of Manhood and the Desegregation of the Armed Forces, 38 UCLA L. REV. 499 (1991).

617. See, e.g., ESKRIDGE \& HUNTER, SEXUALITY, supra note 420 , at $388-400$ (collecting materials reflecting opposition to the president's proposal); JANET E. HALLEY, DON'T: A ReAder's Guide TO THE Military's ANTI-GAY POLICY (1999) (tracing the conductstatus arguments through the legislative process).

618. National Defense Authorization Act for Fiscal Year 1994, Pub. L. No. 103-160, $\S$ 571 (a), 107 Stat. 1670 (1993) (codified at 10 U.S.C. $\$ 654$ (2000)). Technically, there are three grounds for exclusion: the service member (1) has engaged in or attempted to engage in "homosexual acts," unless there are findings (essentially) that they were an isolated occurrence unlikely to recur; (2) has stated that he or she is a "homosexual or bisexual," unless the member can prove that he or she has no "propensity" to engage in "homosexual acts"; or 